Portland State University

PDXScholar

1972

\title{
A gold dream in the Blue Mountains : a study of the Chinese immigrants in the John Day area, Oregon, 1870-1910
}

Chia-lin Chen

Portland State University

Follow this and additional works at: https://pdxscholar.library.pdx.edu/open_access_etds

Part of the Asian American Studies Commons, Ethnic Studies Commons, and the United States History Commons

Let us know how access to this document benefits you.

\section{Recommended Citation}

Chen, Chia-lin, "A gold dream in the Blue Mountains : a study of the Chinese immigrants in the John Day area, Oregon, 1870-1910" (1972). Dissertations and Theses. Paper 962.

https://doi.org/10.15760/etd.962

This Thesis is brought to you for free and open access. It has been accepted for inclusion in Dissertations and Theses by an authorized administrator of PDXScholar. Please contact us if we can make this document more accessible: pdxscholar@pdx.edu. 
AN ABSTRACI OT THE THESIS OF Chia-Lin Chen for the Master of Arts in History presented September 5, 1972.

Title: A Gold Dream in the Blue Mountains (a study of the Chinese Immigrants in the John Day area, Oregon, 18701910).

APPROVED BY MEMBERS OF THE THESIS COMMTTTEE:

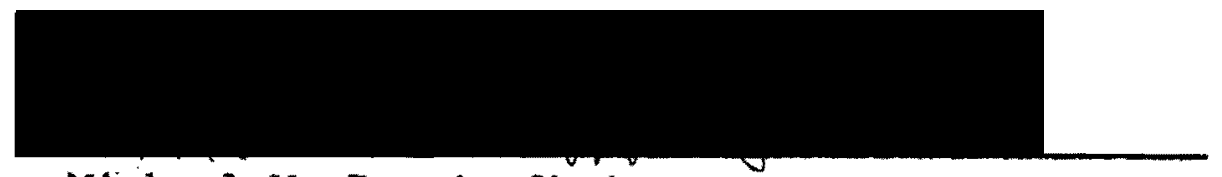

Michael M. Passi, Chairman

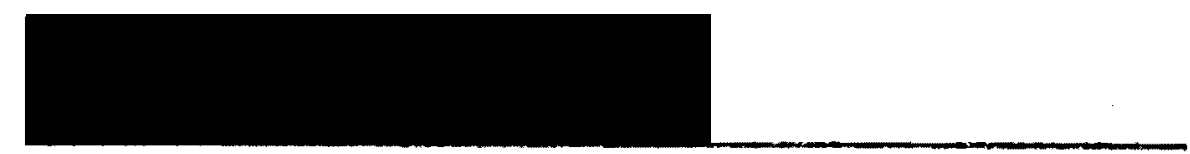

Bernard V. Burke

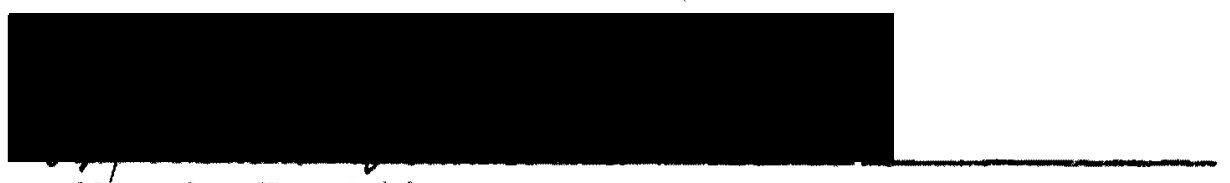

Morris K. Webb

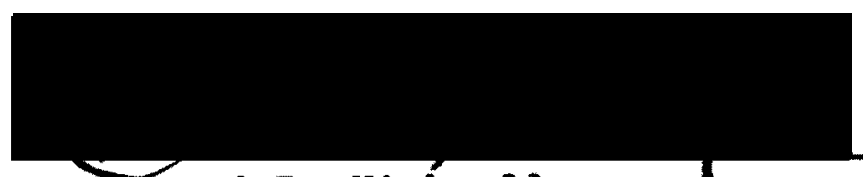

Leonard B. Kimbrell

More than one hundred years have passed since the Chinese laborers first landed in this country in the mid-nineteenth century. Yet their history remains cloudy. This phenomenon is quite understandable if one considers the facts that most of the laborers were illiterate, did not have the ability, and never intended, to speak for themselves. It is true that many scholarly works have been published, but few were written 
by Chinese historians. As a matter of fact, Chinese scholars are unaware that a small number of their countrymen played a strange, pitiful role in American history. The published works reflect the viewpoint of only American observers.

The labor of the Chinese workers was indispensable to the development of the frontier West at a time when resources were abundant and labor hands were few. So much work had to be done: building railroads and dams, digging mines, clearing farm lands, canning salmon, etc. And the Chinese were welcomed to every line of manual work. There was a time when "nearly every family at Astoria of Oregon and Olympia of Washington hired a Chinese as servant," as some writers claim.

When the great number of whites noved in from the EAst, along with them came the floating laborers and the European immigrants, as well as the labor union. Conditions changed rapidly, the Chinese found themselves not only excluded from all employment, but persecuted everywhere. California was the state which first utilized Chinese labor and first expelled it. This unfavorable circumstance forced the Chinese to flee from California to other states.

The purpose of this paper is not to give an account of how the Chinese were maltreated in a country known as a free, equal land opened widely to the whole world, but rather tries to find out how they survived, what were their daily problems, sorrows, and happiness, if any, and whet were their inner feelings, their attitudes toward the white hosts. In short, 
the paper is written in an attempt to reconstruct their life in an alien land. In addition, the paper tries to answer the question why this oriental group appeared so peculiar in their behavior, as some whites commented, that they were both condemned and contemned.

one of the crucial problems facing the researcher in the field of early Chinese immigration history is the lack of original materials. This is the common defects in all the published works on this subject. Fortunately for the author, by an unique chance, he was able to study numerous objects left in a Chinese grocery store, the Kam Wah Chung Co., at John Day-a small town once a busy mining area in Eastern Oregon. The pioneer artifacts in this town are disappearing, though the gravels of the old gold placers are still visible along the hillsides and canyons. "But the queer old building of the Chinese store is still standing stubbornly, as it did one hundred years ago, on a road called Canton Street.

So many objects were left in the building that the city of John Day is endeavoring to open it as a museum. From a historical point of view, many of these objects are very valuable. Amorg them are a great number of letters. Some were sent to the laborers from their families, in care of that building. Other were from the laborers to their homes, and for some unknown reason had not been sent to China. They are unique and of special importance to this paper. Perhaps nowhere else in the United States, or in War-torn China, can one find such a number of first hand records about the early 
Chinese in this country. Although few significant events, romantic affairs, or anything exciting can be expected of them, still, one can reconstruct a plain sketch of their life from these materials.

The paper, though it only presents a small picture of the Chinese group in Eastern Oregon, is aimed to serve, hopefully, as a footnote leading to an understanding of how the early Chinese immigrants once lived in the Pacific Northwest. 
TO THE OFFICE OF GRADUATE STUDIES AND RESEARCH:

The members of the Committee approve the thesis of Chia-lin Chen presented September 5, 1972.

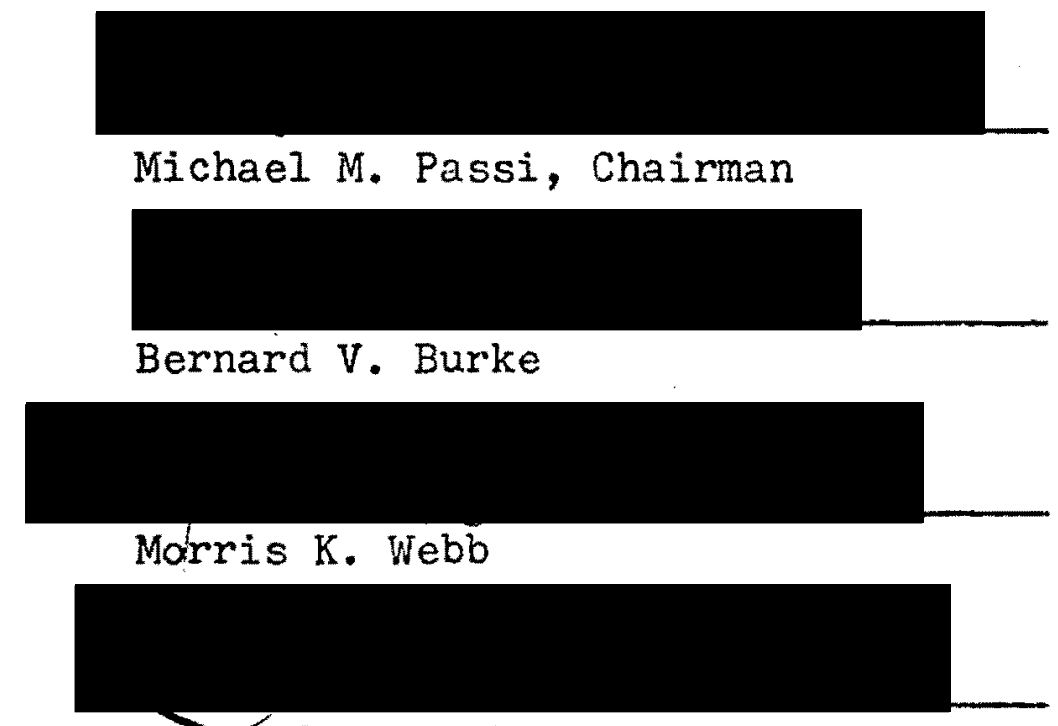

Leonard B. Kimbrell

\section{APPROVED:}

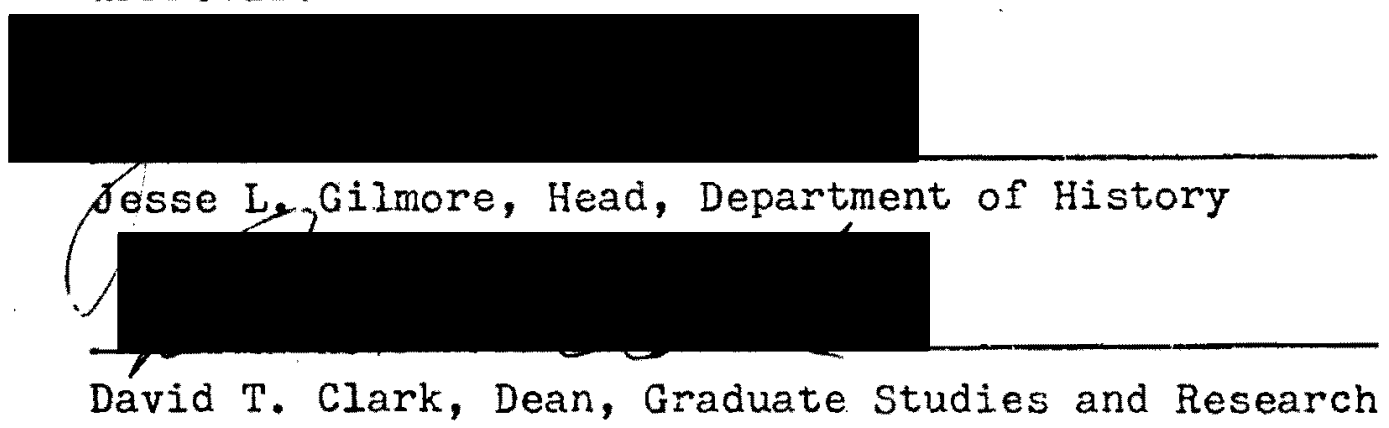

September 7, 1972 . 


\title{
A GOLD DREAM IN THE BLUE MOUNTAINS
}

\section{A Study of the Chinese Immigrants in the John Day Area Oregon, $1870-1910$}

\author{
by \\ CHIA-LIN CHEN
}

A thesis submitted in partial fulfillment of the
requirements for the degree of

MASTER OF ARTS

in

HISTORY

Portland State University

1972 
ACKNOWLEDGMENTS . . . . . . . . . . .

LIST OF TABLES ................

LIST OF FIGURES . . . . . . . . . . .

VI

CHAPTER

I LIFE IN CHINA'S VILLAGES . . . . .

II OREGON AND ITS CHINESE PROBLEM . . . . 25

III STATISTICS ABOUT THE CHINESE IN THE

$$
\text { JOHN DAY AREA, 1870-1880 . • • }
$$

IV THE FORMATION OF A CHINESE COMMUNITY. •

$V$ THE KAM WAH CHUNG COMPANY AND THE LIFE OF THE CHINESE IN JOHN DAY AREA -

VI RELIGIOUS LIFE AND NEW YEAR IN THE

CHINESE COMMUNITY . . . . .

VII THE DECLINE OF THE CHINESE COMMUNITY

$$
\text { AT JOHN DAY . . . . . . . }
$$

VIII CONCLUSIONS . . . . . . . . . 


\section{ACKNOWLEDGENENTS}

My thanks go first to my teachers: Professor Michael M. Passi inspired me in writing this thesis and advised me closely at evey stage; Professor Bernard V. Burke whose constant encouragements and invaluable criticisms greatly improved this paper; Professor Gordon B. Dodds and Professor Morris K. Webb read successive drafts with examplary patience and comments.

I am deeply indebted to the staff of the Oregon Historical Society, especially to the chief librarian, Matthew Cullen, for every help rendered to me.

To Mr. Gordon F. Glass and the Kam Wah Chung Museum Committee of John Day, Oregon, I gratefully acknowledge their generous permission to use the unique materials in that Chinese building. Their zeal and endeavor to preserve this old stone structure represent today's real American attitude toward the early Chinese immigrants.

I also owe a great deal to Mrs. A. M. Bartholomae, Miss Patricia Byrd, Mr. John Fraley, Iibrarians at Portland State University's library. They not only helped me in various ways but also kindly corrected my drafts. Among those others who read and correct my writings are Mrs. Kristine Roley and Wr. Nark Weber. My thanks are also due to Mrs. V. I. Hazeltine, Mrs. Janice Justice--Curator of the Oliver Historical Museum, Canyon City--Mr. Bot Wing, and Mrs. J. W. Murray, for providing me a lot of valuable information. 


\section{LIST OF TABLES}

TABLE

PAGE

I The Chinese in the United States.. . . . . 57

II The Chinese in Oregon, 1860 . . . . . . 58

III The Chinese and the Total population, by

Counties in Oregon ... . . . . 59

IV Chinese and the Whole Population in Grant

County ............. 60

v Occupations Other Than Mining in the John Day

Area ........... 61

VI Population and Miner in the John Day Area. . 63

VII The Chinese in John Day Area . . . . ... 63

VIII Age Statistics of the Chinese in the John Day Area . . . . . . . . . . . . 64 


\section{LIST OF FIGURES}

FIGURE

PAGE

1 The building of the Kan Wah Chung \& Co. . 172

2 Lung On and Doc Hay . . . . . . 173

3 Doc Hay in his twenties . . . . . . 174

4 An opium pipe . . . . . . . 175

5 Doc Hay's herb room . . . . . . 176

6 A business note ........... 177

7 Japanese goods ............ 178

8 The receipt of a fine . . . . . . . 179

9 A letter in Chinese ......... 180

10 A donation to the Chinese government ... 181

11 A lottery ............ 182

12 A letter from a cook ......... 183 


\section{PORTRAIT OF A CHINESE LABORER, I.}

\section{WHERE SHALL I GO FROM HERE?}

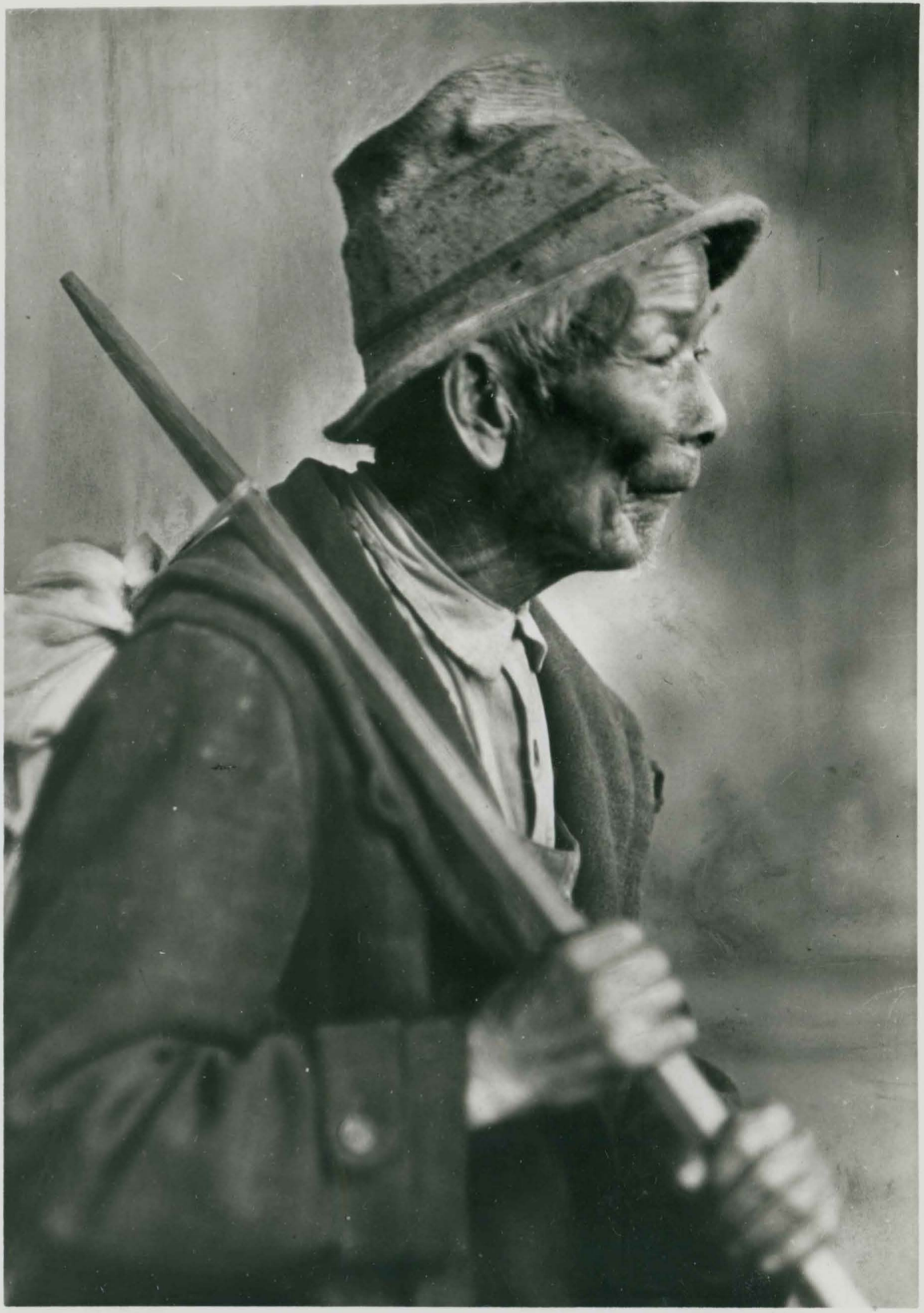

Oregon Historical Society 
PORTRAIT OF A CHINESE LABORER, II.

I AM FINE, THANK YOU.

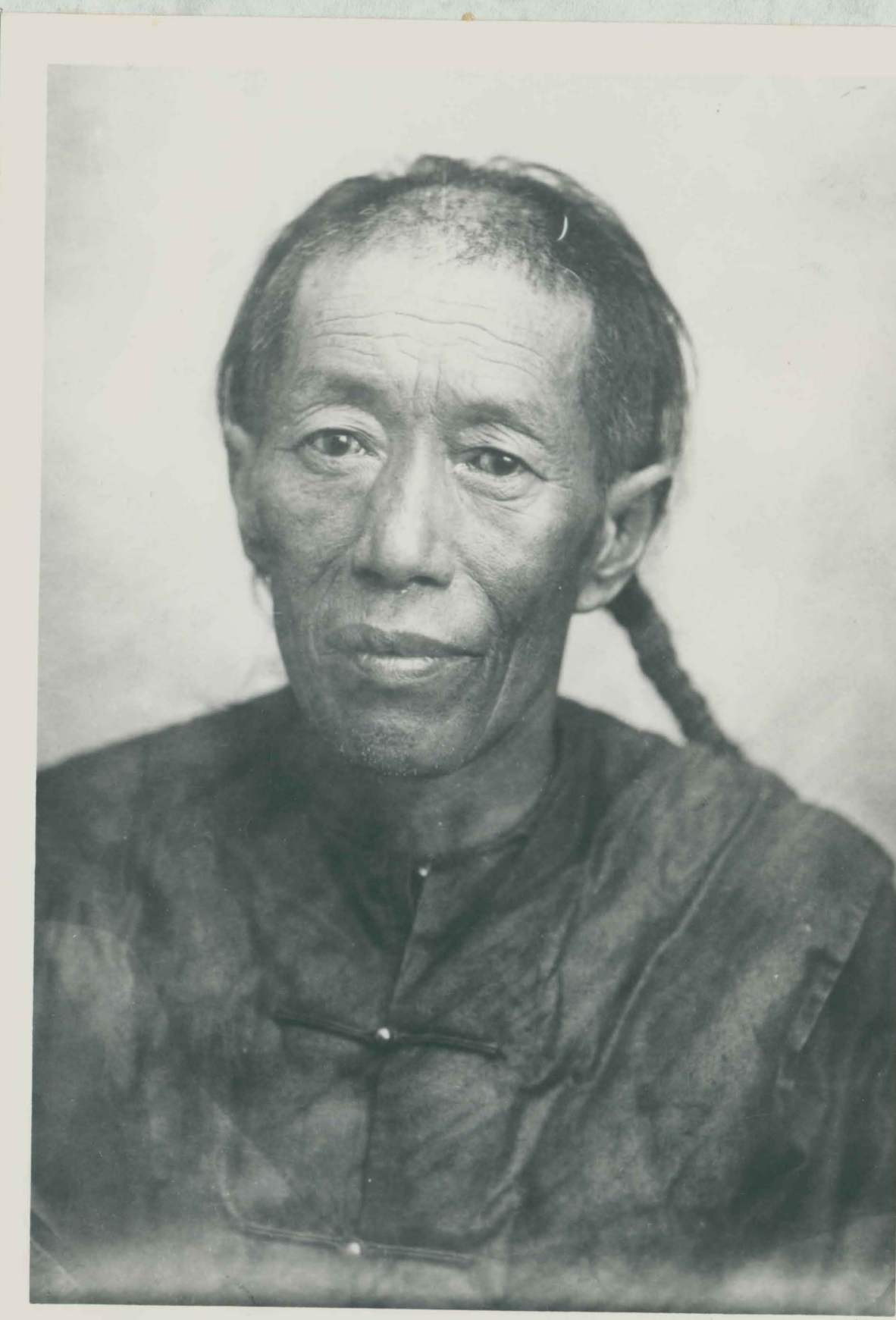

Oregon Historical Society 


\section{LIFE IN CHINA'S VILLAGES}

The city in China is usually the seat of a county, for district). In the nineteenth century, the city was of lesser commercial importance than it is today. Rather it was a place of residence, safer from bandits for richer people, with a thick, tall wall around it. A city consisted of streets, shops, workshops, hotels, restaurants, schools and markets, much like those in any other nation. Houses were commonity small and low, because of the limitations of building materj.als such as wood, brick, and stone. However, by means of connecting many. small buildings closely together, families of three or four generations could reside together, comfortably, sometimes as many as one hundred members or more.

Surrounding the city were big or small towns. Some were much larger than the average size city; others only slightly bigger than a village, with one or two streets, and a few shops: a grocery shop, meat market, blacksmith shop, drug store, pastry shop, and a shop for incense and candles. Dism tance from one town to another varied from twenty miles up to hundreds of miles. In South China, owing to the dense popuiation, the distances were shorter, compared to those in the north. The market day took place at towns in turns. In some districts, the tow had market day every third. A foreigner sometimes would surprisingly find that a tiny, quiet torm would become a huge market overnight, crowded with country 
cousins, noisy small businessmen, jugglers and travelling quacks, full of all kinds of goods, gay finery, and products brought in by the farmers such as vegetables, fruits. eggs, chickens, small pets, pigs and oxen, toys, tools, hand crafts and so on. The market day started early in the morning and ended in the mid-afternoon. Then the town returned to its ordinary quietness again as the people went away.

Outside the towns lay the farming fields with fillages dotied near and far. The cock's singing and the dog's barking from one village could usually be heard by the other. on the other hand, some villages in the hilly areas were so isolated that the inhabitants rarely saw a new face, and possibly visited a city only once or twice in their life time. They would be born there and would mostly die there. Imprisoned in his small circle, the isolated villager caught sight of the same hills, creeks, trees, and rocks every day of his life.

Life in villages was morotonous, and repeated itseif day after day, year after year, and century after century. "Starting work at sun-rise and calling it a day at sun-set" (日出面作，日没而息) is a classical sentence ably describing peasant iffe more than four thousand years ago, and is still applicable today. Men labored in fields. Women operated around the home. The Chinese character for "man" or "male" (男) made up of "labor," (or strength, or energy) under the "field" (or "land" or "puddle"), clearly impiies that toiling in the earth is man's unshakable burden. In China, man not only consumed all his life in plowing the earth, but himself 
also was trappea by the earth. Iike a plant, he came out of the earth. grew and rooted hinself in the earth, died and returned to the earth. The small patch (or patches) of land which came down to him from his forebears would surely be handed down to his chilcren. His ancestors perhaps lay in the small mounds at the center of his property, around which his plow wound every day. It was his important duty to look after these small graves. His own tomb was probably already dug beside them and was waiting for his ow death.

Compared to man's life of drudgery, the woman's was perhaps even darker. Weaving is for women as toiling is.

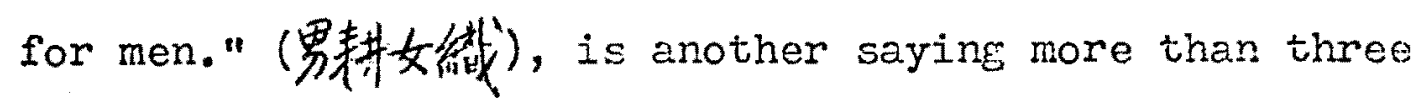
thousand years old. Down to the nineteenth century and after the invasion of western imperialism, although weaving was no longer the major job for women, they did do a lot of work with clothing. They spun (紗纺), twisted hemp. (賏床), raised silk-worms (飬䗗), wound off cocoons (緗䋆), emoroidered, and made shoes. In addition to their general household duties and child-bearing, another important routine was to attend to their husband's parents, which usually was the hardest task of all. Old people are often hard to please. It was not uncommon that a husband "irired", (or "aismissed" or "deserted") his loved wife because his parent did not like her.

Wen might leave the home to make a living in other places, but not women. If the home is a man's castle in the west, then it was the cage for a woman in China. Among other 
reasons which kept a woman horne was her cluty of waiting on her parents-in-law, who, while missing the far-off son, would gain more compensation from the daughter-in-law. Therefore she could not leave home with her hushand.

Even working outdoors was viewed as out of women's element, not to speak of working in the fields. Only the poorest woman or widow who had no relatives to support her would be engaged in outdoor work. (Let us note that the tradition-al social restrictions would be more forcefully applied in the upper class than in the lower class.) General speaking, females, after entering their teens, were not supposed to be seen by strangers. She could no longer play along with her brothers, or male-cousins; she could no longer take part in outdoor activitives. Except on some special occasions, she was rarely outside the door. She should keep herself busy by learning cooking, sewing, and the proper manners of womanhood with emphasis on how to attend to men and the aged so that she would, in the future, be able to please her husband and husband's parents. She could acquire all this knowledge and discipline indoors; there was no need for her to go outside. Thus, from the time of her teen age onward, her life belonged to the house.

Since she lived indoors all the time, the Chinese believed, she did not have to lise her feet to walk frequently at all, so her feet would naturaliy get smaller. This was an erroneous Chinese concept. Associated rith it, was the myth of fortune tellers, who observed that all menial workers 
(because of the hard work and frequent use of their feet) had much larger feet than upper class people. They asserted that "Small feet bring abcut blessings." or "The smaller the feet, the more fortunate you are." and "A man with a big head is the descentant of a ruler; a man with big feet is a mean man." (顽大君子脚大小人). Therefore, people unconsciously applauded small feet and demeaned the bigger ones. Gradually, women bound their feet, to please men, to show themselves more gracefully and to insure good fortune. (The origin of the foot-binding custom and its impact on Chinese culture and society are complicated beyond imagination. It is impossible to give a complete picture here in a few lines.)

Many girls in the countryside began their life of daughter-in-law at the age of eleven or twelve, and sometimes cven younger. Their "husbands" were perhaps still in infancy. This practice prevailed more in the country than in the city and more among the poor than the rich. The girls were brought to live with their "husband's" families to do domestic work. They had to learn all kinds of work around the house from their mothers-in-law. Soon, the entire household was thrown upon them. The poor family that had much work to do could get a maid cheaply, as well as a daughter-in-law. And for the daughte:'s om poverty-striken family, this was a way to get rid of the "useless" daughter. This is also one of the reasons for the high marriage rate among the Chinese labor immigrants, as we will see in the next chapter.

Man, on the other hand, was much more fortunate. From 
the beginning of his life, he was looked upon as the future master of the family. He was the "sead" to carry on the family's continuity. He deserved all kind of special treatment. He enjoyed the privilege of education, if the family could afford it. He got better food and clothing than his sisters, and worked less. He inherited all the family's business and property if he had no brothers to share with. He was the real "gem" (筫兵) in the entire clan (or chia-tzu家疾) if his uncles had no male-children. A poor family wished their sons to bring fortune and prosperity. A family that had become poor hoped that their boys would bring about a "renaissance". And a celebrated family expected their children to at least maintain the family's high standing.

Accompanying these privileges and expectations also came heavy obligations. The son had to be absolutely obedient to the elders, particularly to his father. "The official must die if the king demands it; a son clares not live if his father

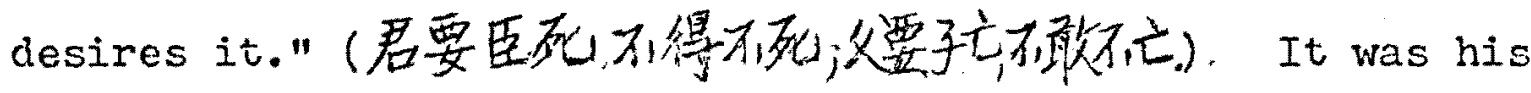
duty to follow the elder's will. He could express his opinion on his education plans, marriage, and future profession, but oftentimes these arrangements were already determined while he was too young to be aware of them. This might make him unhappy later, but the family's protiction, caring, and other privileges he enjoyed compensated for all his losses.

A fanily with four or five generations together was regarded as incredibly blessed. Old men liked to be complemented with: "Look, how happy you are to have such a great 
number of youngsters running around at your knees." And young men seemed ajso pleased to hear: "You are lucky, having parents (and grandparents) still alive."

Except for great natural forces such as fanine and death, or some extraordinarily significant plan for education or business, men usually prefered to stay at home. Departure from family and travel outside was considered as the greatest of unhappy events. "The copper corner of one's hometorn is more precious than the gold or silver corner at the end of the earth (金角落銀角落, 不如家良金同角落) (As the English proverb: home is there the heart is.) The lamentation of the wandering sons comprised the basic theme of Chinese liturature. Thus, men were tied to family by soft anc unbreakabje compassion and lost their wiIl of fighting for betterment at another place.

Religious practice and the invisible world of ancestors under the ground made the family tie more solid and strengthened the loyalty to the home. The family ties: husband and wife, parents and children, brothers and sisters and all the blood relations did not end in death as in other lands, but becane even stronger. To grasp this unique concept, it is. important to note the special phenomenon of thinking of one's dearest oncs, who had gone afur or had dieci, so frequently, and so deeply that one would feel that they were not dead or far away at all, but were quite close and living near by. The Chinese thought death meanit only the corruption of the body, and that life would be transformed to a spirit to dwell 
in the "under world" around living men. They were invisible, although sometimes might be seen in the form of ghosts. They possessed more ability than living mer and could protect, encourage, and purish thern. The two worlds of the living and the dead, were so completely intergrated that all things in this world--the "solar" one (let's use this word)-- were overshadowed by the other--the "lunar" one, (let's use this word, too.) Health or illness of the body, success or failure in business, prosperity or poverty were all possibly affected by the dead. Paradoxically the "happiness" or "sorrow", the economic conditions good or bad, in the "lunar" world depended upon the "solar" world. The dead needed housing, clothing, food and money, which could only be furnished by their living children. Iike the Greek gods, the Chinese spirits in the lunar world had all the needs and desires of the living. (Sometimes, the living one and the dead one could even get married!) The more living children they had, the more material things they could get. If they, the dead, left no living children, then they were surely the poor and miserable souls in the lunar communities. Thus, Mencius remarks that "The most serious unfilial piety of the three leading ones is leaving no off-spring (by not being married) to take care of the anccstor-sacrifice." And the Scripture of Filial Piety says: "At the top of the three thousand penalties is unfilial piety." That was why almost all peovle jn China married. Even the pocrest would make any effort to get a wife, (or a son). 
All the kinships in the solar world continued to the lunar world. Death in onevorld meant re-joining the family in the other. Thus, the family would be united forever by death. How sad would a person be if he died, not in his homeland, but in some place far array. He had to "live" alone, and received no sacrifice. This was one major reason why Chinese would arrange to die at home at any cost.

"Filial piety" (孝川頁) are the key words to understanding the Chinese community structure and the Chinese character. The Chinese laborers in America were regarded as submissive, covied and peaceful. These characteristics all originated from special concepts about family life.

Here is another different perspective about the physical body. To be a person in the society meant bo be a son in the family. To be a son was not "his", but belonged to his parents. Even his body was not his, but had been gotten and borrowed from his parents. The son had no right to destroy his body including every hair on it. Instead, he should take care of it as much as possible.

Here is a story which might illustrate this idea. During the period of the Three Kingdoms (220-280 A.D.), a general, while fighting, was hurt by an arrow which went through his eye. He pulled it out but unfortunately, his eye-ball vas also pulled out. This made him so j.ndignant that he shouted "The eye is of my father's essence and my mother's blood. How can I throw it away?"（父精好血不可新如） And 
without hesitation, he swallowed it down. It is thus very easy to understand that the damage made on a child's body literally hurts his parent's heart. In order not to make one's parents worried, or hurt, one should take care of his physical condition. A good son should avoid fighting if he could, as fighting usually resulted in physical injury.

Coming to the United States, the Chinese laborers were outnumbered by the whites. The savagery and the cruelty of the frontiers-men made the chinese believe that they were living among real barbarians, both whites and reds. Their bodies were smaller and shorter. They did not have weapons. Above all, they were unprotected by law. Therefore they were always compelled to submit--the only alternative available to them!

They were cowards as some Americans asserted. But viewed from another side, they were the bravest! Breaking all shackles of culture, religion, language and emotion, they came to the Gold Mountains in an attempt to relieve their families of economic difficulty, at the risk of their own lives.

Life in the countryside was quiet and unexciting, but not lacking in pleasure. Festivals and religious activities always generated welcome relief from the rural monotony. Arrong a number of religious holidays, the three important ones are: Ching-ming, Mid-seventh-month Day and Mid-autumn Day. Ching-ming is a day for restoring ancestors' tombs. On that day, flowers, fruits, candy, wine, and other items would be 
brought to the graveyard to offer to ancestors. As this day is the first big holiday in spring (early April by the western calender) everyone was happy to take part. The weather is getting warmer, green color is coming back to fields; wild flowers open with butterflies dancing around. The air is cool and fresh, particularly good for women who were almost cut off from nature. Since Ancestors' tombs were sometimes scattered distantly, it would take several days to get through the work of cleaning. Food for religious rituals was well prepared. Since spirits do not literally eat, it would eventually go into the stomach of the tomb-cleaner. Tomb-cleaning had an effect of refreshing the fading memory of the young generation about their long past ancestors. It is usually on this occasion that the history of their rcmote ancestors was told to children. The Mid-seventh-month day (usually in late August or early September by the western calender) was also connected with ancestors. Another name for it is the Spirit Day. This day not only honored one's ancestors, but also kindly served to console the lone, poor spirits who had unfortunatly left no children behind them, and thus received nothing from this material world.

The Mid-autumn Day is more a harvest festival than a religious day. The crops were harvested or ready to harvesi. With a relieved feeling, people spent this day in celebration or in thanking heaven. A special feature of the day is dinner, particularly the eating of the moon-cake by the whole family 
under moon light. On that night, the moon is full (or, reunited again, to use the Chinese expression), and is thought to be the largest, and brightest of the year. So also should be the family. Like the American Thanksgiving Day, family members who did not live at home would come back for a family reunion on this day. Eating the moon-cake together, in the silver-like moonlight, and listening to tales about the moon from the elders, the whole family seemed to "bathe" in the lake of happiness.

Other festivals such as the May-Fifth Day (or the Dragon Boat festival), the Lantern Festival (in the Chinese midfirst month), and the new Year are all colorful and unforgetble to every Chinese.

Aside from the regular holidays, there are some other special days and ceremonies, for example, the birthdays of gods. Since they are gods, they were much mightier than one's ancestor, and ought to be treated very respectfully. As a result, the birthdays of certain gods were elaborately observed and became the most exciting days in the countryside. Very often the ceremonies lasted for several days with much spending of money. People from hundreds of miles around would come to join. Actors were invited from far-off cities to perform operas in honor of the god, which might be the only chance for the villagers in their life to watch a play. Each viliage had tiny and poorly constructed temples. But some villages had magnificent temples which served, beside 
their religious functions, as social activity centers. And its tralls and ample yard provided the best playground for young chiltren in the countryside. Sometimes the classroom or the school of the village was only available in temples. Children raised in this environment were undoubtedly impressed deeply by religion.

Boys in the village did not have much chance to attend school. At best, they might get from one to two years schooling if the family could afford it. otherwise, they all remained illiterate. During the farming season, they usually worked with the adults in the fields. In this way, they acquired the necessary peasant training. The ox was the main source of animal power in South China, and the task of leading it out to the hillside for grass was a boy's favorite job. He usually had a good time singing folk songs, playing games, and making small fires for cooking while the oxen grazed.

They were all boys; girls were seldom among them. As we have noted previously, girls were separated early from the boys. This segregation later helped the males in getting used to the life in the all-male chinese communities in America.

The absence of girls did not deprive Chinese boys of fun. on the countrary, they acted even more free and wild. They roamed from one hill to another, jumping and running like wild horses. Picking fruits, climbing trees, chasing 
small animals and searching for little insects were all favorite activities. Swimning in poois, catching fish in streams, or stealing things to eat from somebody's field, were exciting! Making kites and flying them was also fun. If they got tired of all these, then they would hide in some corner or behind the graveyard to gamble.

Gambling marked a black spot in the Chinese character. The custom can be traced far back to the time of Confucius, and perhaps even earlier when it had already become a popular "national game". For many reasons, outdoor sports which are popular in the western world were not welcomed by the Chinese. Hunting was thought to be cruel. Fishing took too much time. Swirming was not safe since there were not many swimming areas except in dangerous waters. Horse racing was rare since horses had to be used in farming and transportation. Other sports such as baseball, basketball, football and so on were all foreign to China; only in recent years have Chinese learned such sports. Besides, these sports were not at all suitable for Chinese peasants. Since they engaged in hard work, they did not need any more physical exercise. Rather, they enjoyed taking a rest or playing games of mental activity. Gamoling naturally became the "national pastime."

The lack of outlets for relaxation was also a factor in the popularity of gambling among the Chinese. There were no theatres, clubs, parties or other amusements in rural life wheremen could relax. Despite the fact that the Chinese 
people generally acted submissive, humble, and polite to their elders, leaders and culture, deep in their nature they wer 2 indepcndent, proud, and rebellious. Gambling, like Chinese society, had a set of rigid regulations. Yet, by employing one's wit and skill, plus a little good luck, it was possible for everyone to win on the equal ground. In gambling, a man was on his own. He was his own master, not anyone's son or subordinate. He used his own judgement to act, without disturbance or interference. Here, people who could not, or had no right to, express themselves creatively in "real life" found they could do so in gambling. Gambling was, in this sense, a game of self-fullfilment, self-release, social-rebellion and family-liberation. It was an antidote to the rigidness of chinese culture. Once the found "himself" in the excitement of gambling, he would never leave it. That was why the Chinese laborer in America was generally indentified as a gambler.

But life in China was not so pleasant. Pelple in vil:lages only played gambling games on the new year or some other festival days. For the rest of the year they had to strive to keep alive. As a matter of fact, the struggle for survival usually was indescribably hard. The fundamental problem came from the lack of food. From tine immemorial famine had been an ever recurring scourge. A study completed in 1920's by students of the University of Nanking brought to light the startling fact that between the years 108 B.C. and 
1911 A.D. there were 1828 famines in which millions died of starvation. The famine of 1877-1878, for example, claimed 9,500,000 lives, and the one of 188?-1889 even more. In 1911, about 2,000,000 died, and in 1916 about 8,000,000. The great famine that occurred in North China in 1920-1921 took 500,000 lives, and nearly 20,000,000 were reported "destitute." 1

Among the many causes: that contributed to famine were inadequate farming land and overpopulation. China has about 2,000,000 square miles of arid, practically uninhabited country, which can support little more than nomad populations. The good and fair lands were tilled to every inch of the soil, except Manchuria and the Far West, for raising food. Yet it could not yield the required food for the soaring population. It is estimated that to provide for a family of five required 4.7 acres in the central and northern China where the staple food is wheat, and 1.7 acres in southern China where the main food is rice. But 33 per cent of the holdings were less than on acre, and 55 per cent were one and one-half acres or less, while the number of large farms was very small. ${ }^{2}$ It is apparent, therefore, that the bare food requirements for a normal year was greater than the production.

Parallel the inadequate land was the population problem. on the eve of the Taiping rebellion in 1850, the population of China was probably close to 430 millions. 3 The density as a whole was about 268 persons on every square mile. This figure, however, does not show the conditions of the people. 
Half of the total population of China occupies but a quarter of the total area of the coutry. The population saturation point had been reached in the eastern provinces where the number of inhabitants to the square mile varied from 980 in some village districts to 6880 in others. (In the most densely peopled area in India, parts of Bengal, there were 1162 peopie on every square mile of cultivated land. $)^{4}$

This overcrowding of the land made impossible the collection of any reserve of foodstuffs. A good crop did not result in a surplus of grain but merely provided the people a better diet for a short tme. Thus when a poor year occurred the whole countryside found itself without food.

While the fundamental causes of famine were traceable to the economic circumstances in which the people lived, the immediate cause was usually the result of some natural phenomenon. Probably in no other country were the natural features less favorable to the inhabitants than in China.

Drought and flood were two arch-calamities in China. Statistics indicate that during the Manchu dynasty (1644-1911) there were, on an average, 27 droughts and 44 floods per century in the home province of Chihli alone. The great drought of 1877-1878 affected 300,00 square miles. ${ }^{5}$ The Yellow River, which lay with its bed above the level of the surrounding coutrysice, changed its course frequently: In 1852 the River experienced calamitous floods; in 1888-1889 it made a further disastrous change, with its protective dykes 
impeding the drainage of the flood vaters to the sea.

Locusts were another naturel cause of famine. This pest, which consumed the growing crops, left the coutryside as barren as a protracted drought. The people of a locustinfected district were oft-times subjected to epidemics caused by the decayed insects getting into wells, pools and streams thus: poisoning the drinking water.

Beside the natural disasters were wars, both internal and external. No single event in the nineteenth century so shocked the entire nation as the Taiping rebellion. Their leader, Hung Hsiu-chuan, a poor Cantonese, started the revolt in 1850 and occupied Nanking in 1853 as the capital of their. "Heavenly Kingdom of Great Peace." The Manchu dynasty was nearly overthrown. The Taiping war lasted fourteen years, until 1864, with the devastation of 16 provinces and no less than 600 cities; 20 millions were killed, and the richest parts of China--the Central and the South--were ravaged. The Nion-bandit movement, also a peasant rebellion which originated in some villages in south Shantung and north Kiangsu, was reinforced by the remnants of the Taipings and expanded widely in the Central and Northern regions. The movement was active for nearly two decades.

Coupled with the internal upheavals were the invasions of the Westerners, economic, as well as military. The Opium Wat, or the First Anglo-Chinese Was, of 1839-1842, the Second Anglo-Chinese War of $1856-1860$, the Sino-Japanese War of 1895 , 
and the Boxer Rebellion (or the War against Eight Foreign Nations) of 1900, were a].I military engagements, costly and disastrous to the Chinese, in which not only a great part of territory was ceded and sovereign rights were lost, but a tremendous amount of indemnities had to be paid which imposed a heavy economic burden upon the people. ${ }^{6}$ This burden, theoretically, was shared by every countryman fairly, according to his financial condition. But actually the heaviest burden fell on the poor, because the Manchu Government was corrupt and avoided taxation of the powerful classes.

War carried by the Westerners against the Chinese was to clear the way for trade. The industrial revolution which began in the second half of the eighteenth century made the Western countries, especially England, seek a world-wide market. China, with its more than four hundred million population was consedered the biggest potential market. Yet China was not interested in trade with other nations, nor was she willing to alter her centuries-long restrictions upon foreign trade.

China was a self-sufficient country based on agriculture. About eighty per cent of its people were peasants who produced almost everything under the sun. Indeed; China was such a large country, nearly all her needs were found within its confines. Despite the recurring famines, China was regarded by its people as the loveliest and richest land in the world. Above all, her culture was the highest, and her 
historical record was the longest. No other nations could match her in these respects. So the chinese had not the least desire to communicate with others, either in culture or in commerce. It is quite true that there was some international trade going on for centuries at some spots along the northern border, and at some ports along the southeastern coast, such as Chuanchou in Fukien, and especially Canton'in Kwangtung. But all this trade was initiated by the small neighboring nations and consented to as a mercy by the celestial Court with a view of "letting the poor small neighbors gain some tiny profits lest they will make troubles."

Ignoring her benevolent motive, China had profited from this trade because her three famous export products--tea, silk and porcelain--were always in great demand in the world. Consequently, the value of exports ofter: exceeded that of imports. This tendency was accelerated in the later eighteenth century when the Europeans arrived at Canton to join the trade, although the amount was negligible in relation to the total Chinese economy. This trade imbalance, unfavorable to the foreigners, was soon reversed when the English employed the smuggling of opium from India. Thereafter, "black gold" (a name for opium used by some chinese) not only found the ready market of a four-hundred-milizon chistoners, but also had to be paid for in silver, for it was contraband cargo, not exchanged for other cargo. It was in this manner that silver began to flow out of China. The more people indulged 
in the use of opium the more silver flowed out. Before long China was faced with a specie famine which upset its entire fiscal system.?

The Chinese internal currency system was based on silver and copper. "Silver to be used for tax payment, for the payment of salaries by the government, and for all calcula-: tions of the official treasury," writes an American historian; "copper to be used for local buying and selling, especially in the local agricultural markets." The historian continues:

As a result of the outflow of silver, the internal value of silver to copper was changed from $1: 2$ to $1: 3$. This greatly aggravated the financjal problems of the Chinese farming population, whose tax and rent payments were calculated in silver but whose income was based on devalued copper. 8

Following the opium trade there was increasing penetration of western goods into the Chinese market. Its. impact was profound and beyond the comprehension of the western capitalist mind, in whose eyes the total amount of the trade was comparative small. The Opium War opened up the treaty ports, and the Second Anglo-Chinese War broadened foreign trade to meet the Westerners' ambitions. Quickly the western commodities were to be found in every corner of China, among them cotton textiles were the most important. Western textiles were good in quality and reasonable in price, and the local product could not compete with them. The outcome was obvious: the village industry was wiped out, and more people were driven from their employment. Indeed, the entire traditional economic system of the nation was disordered to its 
very root.

To sum up, the conditions in which the people lived after the Opium War were political deterioration, social insurrection, the pressure of overpopulation, the intrusion of the foreign economy, and wars, internal and external. AIl worked together to pressure the poorer elements and force. them either off the land or from their jobs.

Three sequels awaited them. One was to starve to death, as million in the north of China did. The next was to rebel, as the Taipings and numerous bandits did. The third was to emigrate either to Southeast Asia or to the New Horld, as the coastal inhabitants in Kwangtung and Fukien did.

Kwangtung and Fukien are the two southeastern provinces which furnished most of the emigrants from China to foreign countries. The coolie emigration to Cuba and South America, in the hands of the Portuguese and the Spaniards, according to Mary R. Coolidge's exhaustive study, was largely from Fukien, while the emigration to California was almost exclusively from the districts around Canton in the Pearl River Delta in Kwangtung. 9

For centuries, these two maritime provinces were the most important places for the conduct of foreign trade. Geographically, Kwangtung is closer even than Fukien to Southeast Asia, therefore, its capital city, Canton, eventually surpassed its rival city, Chuanchou in Fukien, to becomechina!s biggest trade center, long before Singapore and Hong Kong coming into 
being.

By the route came the merchants from near-by small nations, as well as from India and Arabia, followed by the Europeans--Portuguese, Spanish, Dutch, English, French, German, and Italian--and at last, American. By contact with foreigners, the people in this area acquired some slight knowledge about the outside world, and were more aggressive and more adventurous in bettering their economic condition than their inland countrymen.

During the foreign wars, Canton had seen most of the fighting. Disturbance and turmoil lasted longer than in any other place. The other treaty ports opened by the Treaty of Nanking in 1842 ruined the trade monopoly formerly held by Canton. The end of the monopoly of trade and the growing competition of new trade ports, especially Shanghai, affected the trade routes and upset the existing transportation system. Groups of porters and boat people were affected. Thus formed a surplus laboring class, waiting for any opportunity to make a living. At this time news arrived of the discovery of gold in the Sacramento Valley of California in January, 1848. The spring of that year had witnessed a great excitement in Canton as well as at the seaports on the eastern coast in the United States. 10 And a great emigration movement was under way. 
FOOTNOTES FOR CHAPTER I

${ }^{1}$ Lindsey Hoben, "The Scourge of Famine in China," Current History, Vol. 34 (Spri1, 1931), pp. 63-67.

${ }^{2}$ Frand H. H. King, A Concise Economic History of Modern China, 1E40-1961, (Praege: Pall Mall, 1969), p. 18.

3 Ibid.

${ }^{4} \mathrm{~s}$. Wells Williems, The Middle Kingdom (New York: Paragon Book Reprint Corp, I966), VoI. I, p. 272.

${ }^{5}$ F. H. H. King, p. 19.

${ }^{6}$ In the treaty of Shimonoseki of 1895 , China had to pay an indemnity of 200,000,000 taels of silver to Japan. In the Protocol of 1901 which ended the Boxer Rebellion of 1900 China had to pay an indemnity of 450,000,000 taels, which was allowed to be paid within a period of 39 years with a yearly interest of $4 \%$, the total amount was $982,230,000$.

7 Some American scholars do not think that the smuggling of opium caused too much silver flowing out of China, but the Chinese historians do, see Franz Schurmann and Orvilie Schell, Imperial China (New York: Random House, 1967), p. 133.

8 Franz Michael, The Taiping Rebellion (Seattle: University of Washington Press, 1966), vo1. I, pp. 14-16.

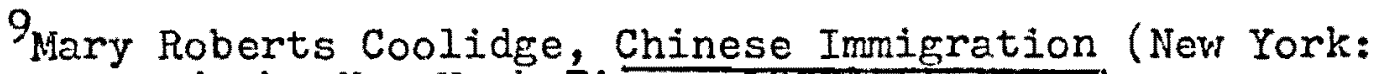
Arno Press and the New York Times, 1909), P. 19.

$10_{\text {Ibid., } 17 .}$ 


\section{CHAPTER II}

\section{OREGON AND ITS CHINESE FROBLEM}

From the dawn of civilization, "gold" has been the most desirable and precious thing in human societies. No one except the great soul, or the idiot, can resist its lure. In China, to discover a gold mine was rare, or has never happened, but to dream of picking up a nugget was very common. Fictions about poor peasants digging up lumps of gold from the farming fields, or laborers running across gold somewhere, always appealed to the masses, though they may not have believed it. Now there came a true story from the other end of the ocean about a place where gold could be "scraped out with a knife and spoon."I Everyone would be a millionaire, providing that he could get to the "Gold Mountains," as they called the United States.

Because of the impassable ocean, the adventure of the laborers and peasants in the Gold Mountains would never have come about had not the Americans been interested in employing them. Shipmasters quickly seized upon the situation, distributing placards, maps, and pamphlets concerning the Gold Mountains. Agents of some railroad companies came to recruit, and prepaid the passages and other expenses for those who decided to go. "The call of the Golden Mountains was ringing in the air of the distressed regions of Canton." "To be starred and to be buried in the sea are the same," was the 
thought in the minds of thousands who fled to thong Kong and the ships. ${ }^{2}$

It is apparent that "to dig up the gold," undoibtedly, played a significant role in inducing Chinese to leave for America, but "to find a job," on the other hand, was the more urgent and the more motivating force. Like all frontier communities, California had a pronounced scarcity of labor, which was accentuated by the rush to the gold fields. The Chinese were looked upon as a veritable godsend. 3 Women were very few, and the Chinese supplied the need for cooks, laundrymen, and the like, as well as that of the heavier work of grain farming, fruit growing, tide-land draining, and manufacturing. So the state cordially welcomed the hordes of cheap labor from China; in the parade of 1850 which celebrated the admittance of California into the union, the Chinese were recognized as adopted citizens. The two first governors of California, Peter H. Burnett and John McDougal refered in annual messages to the Chinese as a most worthy class of adopted citizens. 4 In addition, MoDougal even attenpted in 1852, to encourage the Chinese imnigration by setting up a system of land grants to them. ${ }^{5}$

The greatest demand for Chinese labor would come from the railroads. The Central Pacific, owing to the time requirement set by Congress and the competition with the Union Pacific, as well as inablility to procure white labor, was compelied to employ the Chinese. By 1869, ten thousands of 
them were on the pay-roll. 6 Later, the Southern Pacific lines, especially in California, were built almost entirely with Chinese labor. From their lator came the old siying: "The eastern end of the transcontinental railroad was built by 'whisky' (Irishmen) and the western end by tea (Chinese)."7 Transportation companies had wielded a powerful infueence in promoting Chinese immigration.

At times, every [American] ship available in Chinese waters was put into the service. In 1866 the Pacific Mail Steamship Company entered the China trade, under government subsidy. And a little later the occidental and ariental Steamship Company was organized as a competitor. - Charles Crocker, an official of the latter. company, claimed that both lines could not be run profitably without the Chinese passenger traffic. 8

After their arrival, the Chinese pretty soon found themselves trapped in a hostile land. A typical American frontier community, California was full of lawless adventurers, immoral speculators, cunning politicians, desperate European immigrants. and deadly criminals. In a period when white men carried their lives in their hands and when justice was attained, if at all, by the rope and the gun, 9 the despised and defenseless Chinese were naturally the prey of all the unscrupulous.

They were first treated with all kinds of discrimination, such as high taxes, unjust legislations, exclusion from the ballot. And gradually they were excluded from the witnessstand in the court, which threw them, in effect, beyond the protection of the law, and which undoubtedly gave gorce to 
the endless physical persecution upon them. 10

Riots against Chinese began as early as 1852 when a "Committed of Vigilance" was formed in San Francisco, and Chinese property was burned. ${ }^{11}$ In 1855, conventions were held in many counties to protest the Chinese immigration. In 1862 , the Anti-coolie clubs came into being and a state-wide union of the clubs was formed in 1867.12

At first all these attacks came solely from the working class, who regarded the Chinese as their competitors and usurpers taking away employment from them. They charged the Chinese:

That he is a slave, reduced to the lowest terms of beggarly economy, and is no fit competitor for an American free man.

That American men, women and children cannot be what free people should be, and compete with suci degraded creatures in the labor market.

That they are driving the white population from the states, reducing laboring men to despair, laboring women to prostitution, and boys and girls to hoodlums and convicts.

That the Chinese laborer is a curse to our land, is degrading to our morals, is a menace to our liberties, and should be restricted and forever abolished, and the Chinese must go.13

They also charged the capitalists and companies which employed Chinese workers, declaring that "Every employer who substitutes Chinese labor for that of the citizen sis an enemy to the real prosperity of the state.: 14

From 1867 onward, the Chinese question became of the vital issues of California politics.. As the political parties in the state were equal in strength and as the labor forces 
were already organized and unified, every politician was aware that the vote of laborers held the balance of election. So they seized upon the Chinese question to capture the labor vote. 15 These shrewd politicians saw that the Chinese laborers would be unable to recaliate. Thus anti-Chinese feeling was inflamed by agitators.

Coincident with this political uprising were the completion of the transcontinertal railroad in 1869 , and the coming of depression in the early seventies. The discharge of thousands of Chinese laborers by the Central. Pacific made unemployment in the already crowded labor market more acute, and the Chinese were charged with causing the nation's economic failure. 16

In 1871 occurred a brutal massacre in the Los Angeles Chinese community. Twenty-one Chinese were killed-fifteen hanged on the spot; many buildings were burned, and large amounts of loot were carried away. All these events lasted only a few hours. The nation was shocked, and Los Angeles appeared in the headlines of Eastern newspapers for the first time.17 A grand jury indicted $150 \mathrm{men}$, but only six rioters were sentenced to short jail terms. 18

Similar violence was repeated in other towns, At Vallejo, California, a mob burned and looted a Chinatown. An author gives a brief account of this incident.

When the flames had reduced one house to ashes, a distraught father was seer squatting with his head down beside the charred body of his young daughter. When a hoodlun ran up and kicked the body into the 
air, the grieving Chinese picked up a charred stick "At Madeira, the Chinese settlement was burned at midnight," the author goes on, "and sixiy houses were destroyed. . Up and down the West Coast, at Selma, Delano, Seattle, Tagus, Pixleym, Borden, and many places too small and too isolated to have ever been remembered, the Chinese were hounded and harried out of their homes and jobs."20 In one place, at Truckee, California, one thousand Chinese were driven out in November, 1878.21 "It would be impossible to estimate the number of victims unrecorded. . " sighs the historian Mary R. Coolidge. 22

In october, 1877, the Workingmen's party was formally organized under the leadership of Dennis Kearney, a former Irish cabin boy. Anti-Chinese proposals appeared in every set of their resolutions. The voice that "the Chinese must go" was rumbling like thunder in the sky. On october 30 , the Irish agitator threatened to mobilize 50,000 workers to drive the Chinese either out of the country or into San Francisco Bay.23 If Kearney had really intented to do so, there would have no Mongolians in this country today, for "watching the wheat game is harder than excluding the Chinese," said he. 24

From 1871 onward, throughout the period of the Kearney agitation, no "Chinaman" was safe either in person or property. It was common for the chinese immigrants to be met at the wharf with a riotous welcoine. Stones, clubs, potatoes and 
mud were thrown at them until "their scalps hung down the sides of their heads, the blood on the streets showed the tracks which they had pursued. . "25 "If we follow the yellow thread through those troublous years," writes coolidge, "it seems a miracle that any Chinaman remained alive in the country." 26

It was under these circumstances, that the "Chinamen" fled to the mountains, to the remote country districts, and dispersed to other states, especially Idaho, Washington, Oregon and the mountain states both for safety and for work. Yet their sufferings were not in any case ended. For in the 1880's came another high peak of racial antagonism, widespread over the Northwest.

With the Chinese Exclusion Act of 1882 passed by Congress 27 as the first portent, then came the completion of the Northern Pacific Railroad in 1883, a principal source of employment for many Chinese laborers in Washington state which thrust a vast horde of unemployed workmen onto the labor market. Worst of all was a severe economic depression falling upon the West, which caused thousands of men to be idle. 28 Again Chinese were the objects of grievance and to be cursed. The massacre of September 2, 1885 at Rock Springs, Wyoming, started the racial persecution of 1885-1886. At Rock Springs an entire Chinese village was burned. Chinese men and women were shot and their bodies thrown into fire. How many were Killed is unknown, but at least forty-two were counted dead 
before the dogs and wild hogs ate the corpses. 29

The Rock Spring issue shocked the nation as well as inspired another series of anti-Chinese outrages in other states. And this time, Washington Territory was one of the most excited regions. On September 7, many Chinese were murdered at Squak Valley while others shot at their camps at the Coal Creak mine, King County. 30 on September 25 , the "anti-Chinese Congress" was set up at Seattle, delegates had come from towns of Colby, Black Diamond, Newcastle, Squak, Sumner, Tacoma, Whatcom, Renton and McAllister. 31

The Seattle Post-Intelligencer declared: "The civilization of the Pacific Coast cannot be half Causasian and half Mongolian." On the night of November 3, people of Tacoma routed 200 Chinese to a place south of town on a prairie; "the weather was cold and rainy; here the foreigners were left al] night to find what shelter they could find from rain and cold. From here they eventually found their way to Portland. Following this removal of the orientals from Tacoma, were other expulsions from smaller towns of Pierce, King, Kitsap, Snohomish, skagit and Whatcom counties." 32

Meanwhile over 500 Chinese at Seattle were in a situation even more inhuman. After being threatened for six months, September 1885-February 1886, by mass meetings, demonstrations, and violence, they were at last driven off. 33 During the period of this racial hysteria, Seattle was under martia]. law ordered by Governor Watson $C$. Squire, who called 
for Federal troops sent by the order of the Department of War. Instead of protecting the Chinese, the soidiers came to seattle to beat them up, cut off their queues, and throw some of them into the bay. In addition, a group of soldiers visited the Chinese quarter on the night of November 9, to collect a "special tax." Therefore, a local newspaper remarks: "The chances are that the people will be called on to protect the Chinese. 134

As a neighbor state to Washington, the usually quiet Oregon, with the second largest Chinese population in the United States, would soon be affected by such a climate, Oregon had long been regarded as a state having no "Chinaman problems," in consideration of its constantly growing Chinese population and its mild anti-Chinese record. Indeed, oregon had been a place open widely to the chinese. Therefore, the Chinese swarmed in like the "devouring locusts."

The movement of chinese to oregon may be traced as early as 1851 with the discovery of gold in Southern Oregon and establishment of regular steamer connections between San Francisco and Portland in that year. 35 There seem to have been no Chinese in Oregon before 1851. Bancroft, in his History of Oregon, states that there were no Chinese as residents of oregon in 1850.36 In 1851 gold was discovered in various places in the Rogue River valley; and in the following year the great discovery of Rich Gulch where now stands the town of jacksonville was made. 37 This caused a rush of miners 
to the valley; the inmediate result to Oregon was the growth of many new counties: Jackson was organized as a county in 1852, Coos in 1853, Curry, 1855, anci Josephine, 1856. By 1857 there were several hundred Chinese working in the old mines in the counties of Jackson and Josephine. "The Chinamen are about to take the county," warned a private letter published in the Oregonian in 1857. "They are from one thousand to twelve hundred" in Josephine county, the letter went on, "buying out the American miners and paying prices for their claims."138

Despite the agitated discussion of the early Chinese arrivals in Southern oregon, they did not appear in large numbers until the sixties. Although the Eighth United States census still does not list the Chinese in Oregon in 1860, Bancroft mentions that there were nine hundred Chinese in Jackson and Josephine counties in 1861.39 He further adds that in 1861 these two counties reaped an income of ten thousand dollars from Chinese taxation. 40 one authority supplies instance after instance where the 1860 mining laws of Jacksonville, Jackson county, were replete with restrictive acts against the Chinese, and definitely states that "Jackson Creek in 1864 was given over to the Chinese." 41

The Chinese in Southern Oregon were still active in the seventies and eighties. "These people may be seen in numerous places," The Oregonian, stated on August 8,1868 : Working over many old diggings; and, along the bars of Rogue River. . . in washing out the gold which 
white labor has neglected as too small pay. In some places they have large wheels, driven, by the current,
for raising water for their sluices." 42 the

On February 28, 1877 an editorial comments on depredations constantly practiced against Chinese miners in Jackson county, and tells of their cabins being burned, all their rights violated, and mentions that they were working claims that anyone else would scorn. and that the men concerned in the outrages were not honest miners. 43 With depletion of gold in the region the Chinese left so that the census of 1890 lists only 224 Chinese in Jackson county and 98 in Josephine county' (see Table III in the following chapter).

The discovery of gold near Lewiston in 1860 led the Chinese into Idaho. Soon they were "crowding every one out of house at Idaho City and filling up Boise County." 44 In 1861 and 1862, more gold discoveries in the gravel beds along the creeks of the Blue Mountains, drew more Chinese into Eastern Oregon. Since then the Chinese population grew steadily in oregon. The great portion of the Chinese congregated in the lower Columbia basin, and in the mountain areas of Eastern Cregon. Portland, the greatest metropolis of the Mighty Western River, once possessed the second largest Chinese settlement in the country, ${ }^{45}$ next only to San Francisco; while the small tows in the Blue Mountains like Auburn, Clarksville, Humboldt and Sumpter in Baker county; Granite, Union, Prairie City, Mt. Vernon, Canyon Gity and John Day in Grant county; and Sparta in Union county:; were 
all oases to the Chinese miners in the anti-foreign Anerican desert.

A spectacular phenomenon can be observed by making a comparison between Oregon and California. In the latter, the Chinese population was declining greatly, while in the former, it was growing constantly. More significant was the relative calm of the public mind in oregon toward the presence of the orientals, while in california there had been continual perturbation. Oregon's not-so-easy-to-agitated population was even more striking in the light of the high resentment toward the docile Chinese in Washington to the north, which had a far smaller chirese contingent than that of oregon. 46 Despite the fact that a lot of discrimination existed in the state, such as heavy special license tax upon Chinese miners, unjust ordinances in some cities, and a constitutional provision adopted in 1859 that debarred them from the ownership of mining property, 47 oregon might be generally looked as a reflige for the suffering Chinese. During that unrest and terrible time, Oregon had regularly maintained conditions of peace and order.

one commentator has analyzed this unusual fact as

\section{follows:}

Oregon was made up of transplanted households of homeseekers, - Becalise of the lover and more steady development of oregon no large number of homeless wageearners have ever been caught adrift here [as in California and Washington]. It is to the absence from her population of a large admixture of such inflamable elements that the lack of any heat of resentment against the Chinamen within her borders is to be of 
attributed. 48

Another contributing factor to the lack of awareness of a Chinese problem, was to be found in the "sluggish commonwealth spirit" in Oregon. "The Oregon people," continues the commentator, "were slow to get together in cooperation for the public welfare." 49

But the main reason for "no Oriental problem" in Oregon was the need for Chinese labor.

Oregon has not been able to draw to any extent upon European immigrants for domestic and other menial services. The manning of the salmon canneries, the furnishing of garden truck for the cities, and the supplying of the 'section hands' for the railroads, have also been occupations for which the white wageearners of this part of the country had no relish. Such vocations were freely accorded to the Mongolians. The Oregon quota of orientals years in andout has just about sufficgl to meet the demand in these undesired employments. 50

Still another factor in the more favorable climate in oregon was the strong stand for justice of the oregonian--the leading newspaper in the state. For more than forty years (18651910), under the editorship of Harvey W. Scott, the newspaper took the side of law and order and derounced the agitators and violent in vigorous phrases that exerted a great impact in keeping the innocent Chinese from ruthless assults. 51 'The Oregonian was boycotted for a time by the anti-coolie organizations. 52 In order to have a better understanding of the attitude of the newpaper, the following quotation taken from the March 4, 1886 edition is worth reading, especially in light of the outbreak of the riots in seattle, and the 
excitement that caused among people in Portiand's population:

Within a radius of ten miles of Portland thousand of acres of heavy forest have been cleared away by. Chinese labor; the stum $s$ have jeen removed and the land brought into a fine state of cultivation. Hundreds of white persons around us are finding employment and support for themselves and families in the cultivation and further improvement of these lands. The labor of the Chinese has been the basis of it all. .

This work is of a kind which white men will not pursue for any length of time. . . Contracts let to white men for clearing land have usually been abandoned by them. . They boast of their irresponsibility, and take pleasure in causing their employer disappointment and loss. ...Farmers and others, unable to get white labor that would fulfill its engagements, have turned to the Chinese, who at least show fidelity in this regard. But it is this very quality that makes the Chinese so hated by the irresponsible white who rally at the call of the agitators and pretiended champions of labor. .

- . On the whole, then, the chinese do not deprive white persons of einployment. It they do, in some cases, they plainly make more employment for white persons in others. The employment of white upon the thousands of acres of land opened to cultivation through Chinese labor, proves this; so likewise does the employment of white in large numbers, in connection with the great fish packing industry, which, without Chinese labor as an auxillary or foundation, never would have been developed, and could not now go on.

What is needed most of all in this country is the utterance of sense on this subject, as a foil or check to the floods of injurious nonsense with which it is deluged. . .53

On account of all the factors mentioned above, Oregon

became a place of comparative peace, in the increasingly high tide against the heathen "Chinamen,". in both the seventies and the eighties. Thousands of them after being persecuted in other parts of the country, fled to Oregon, took shelter in its warm bosom and finally settled down. Yet, in spite of its relative tranquility, Oregon was 
not without its problems for the Chinese. The state was not completely immune from the antagonism against chinese because the trend of the times was generally unfavorable to tre Chinese on the pacific Coast. As in California, the anti-Chinese animosity in Oregon had been exploited by the politicians. As early as 1870, Lafayette Grover, the Democratic candidate for governor use the "Chinamen" issue to appeal to the voters. 54 In 1878, William W. Thayer was elected governor on a platform denouncing Chinese labor, and with the support of the Working-... men's Club. 55 Sylvester Pennoyer, a powerful figure in Oregon, who led the anti-Chinese agitation in 1885-1886, was elected governor in 1887.56

Even businessmen used tre timely anti-Chinese psychology to improve their business. For example, McMinnville advertised:

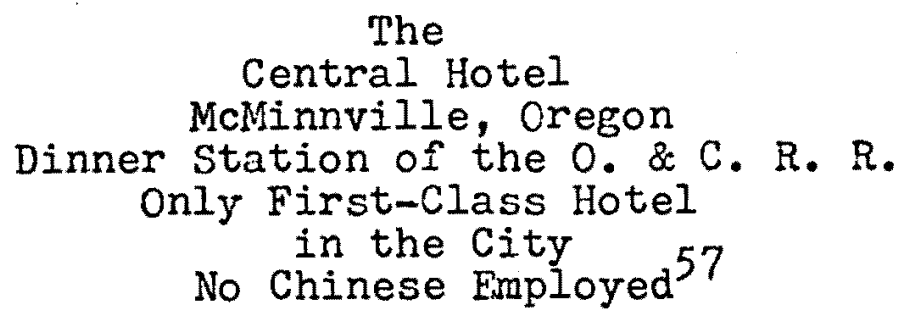

With these anti-Chinese elements in its circles of both politics and commerce, the public mind toward the Chinese was unavoidably more or less imflamed.

The year of 1873 witnessed the first grave anti-Chinese activities in the state. June 18 of that year the oregon Anti-Chinese Association was organized at Portland, F. R. Niale was the chairman, and all members were pledged to 
discourage Chinese immigration, never employ Chinese workers, try to prevent other employers hiring the same, and refuse to vote for any candidate that would not pledge himself to observe the principles of the association. ${ }^{58}$ Its branch organization was formed in Oregon City July 15, 1873.59

on August 2, 1873, occurred the great Portland fire, destroying nineteen blocks in the commercial section. The fire was believed to have been started by the anti-Chinese organization as a means of intimidation of reluctant supporters of their program. ${ }^{60}$ In addition, employers were also threatened individually by some anonymous warnings. One of these warnings reads as follows:

Mrs. Allen, this is to warn you not to hire any more Chinamen. Remember Saturday. one of the twenty-eight. ${ }^{61}$

In view of these circumstances, the Oregonian worried that the city of Portland was becoming a land of hired assassins and incendiaries, and asserted that the allusion to Saturday in the note must refer to the fire of August second. ${ }^{62}$ Yet this seventies resentment against the Chinese was only the prelude to the highly agitated period of the mid-eithties. Located between the two excited states-California and Washington--Oregon almost went as wild as its two neighbors in 1886. In February and March of that year, a racial crisis broke out at Portland while the racial hysteria at Seattle was gradually calming down, On February 12, an Anti-Chinese Congress was held. One hubdred and seventy-three delegates 
attended and openly rejoiced over the success of a similar meeting in Tacoma, Washington, hissed over the stopping of Chinese outrages by Governor Squire of Washington, and formulated an order giving all the Chinese in Oregon forty days in which to remove themselves from the state. 63

Meanwhile the California "riot-breeder,"64 Burnette A. Haskell, arrived to direct the revolt. A torchlight procession escorted him from his steamer to his hotel. "You must drive out the Chinese," agitated Haskell to the people of oregon; "peacefully if you can, forcibly if you must; if necessary, shed blood."65

Under his stir, a great revolt appeared imminent in Portland around February 18. Therefore strong forces were organized to cope with trouble bycivil authorities. On February 17, seven hundred citizens were in arms; new militia was sworn into ssrvice, four companies of militia were encamped in the armory at second and Salmon; guns were loaded and batteries were prepared; horses were hitched for instant service; the court holise was placed under a guard. Two hundred deputy sheriffs were apoointed and the police force doubled. Governor Zenas F. Moody, Sheriff Thomas A. Jordan, Mayor John Gates and Chief of Police Samuel B. Parrish were all on duty in Portland awaiting the attack of the agitators. The signal to quell the revolt was three double taps on the fire bell. Athletic clubs like the Rod and Gun and the Multnomah and many private citizens pledger their aid. The trouble was expected at night as 
the Seattle revolt began at daybreak. 66

The expected trouble, however, did not occur. But a numier of outrages did happened at Oregon City, Yamhill, Mt. Tabor, and several other places. 67 In Portland, the crisis was not over yet, for a new revolution even greater than ever before was at the brink of explosion. A large mob of a thousand people assembled at the court house at noon March 16, 1886. The meeting was commenced by appointing sylvester Pennoyer as chairman and proceeded to pass resolutions that pledged those assembled to deport all Chinese, not to employ any of that race, and to boycott the oregonian. 68

At two o'clock, Mayor Gates appeared and was unable to enter the room; twelve thousand people jammed the ofices of the court house, flooded the hall ways, and even overflowed into the street. Mayor Gates proceeded to the County Court room and invited the orderly elements ta meet with him there. At this meeting the leading men who supported the Mayor were Charles Sitton, Henry Failing and Bernard Goldsmith. This assembly resolved that all have the right to life and liberty, no one was to be prevented from work, or driven from their homes; means were pledged to carry out this program, and law and order was to be enforced and the rioters punished even if it should mean the death of those at the meeting. 69 It was mainly by such a determination of these leading people to support law and order that: the Chinese residents were not eventually ousted from the City of Rospes. 
While the people of the West Coast were wrestling with their Chinese problem, Eastern Oregon, interesting to note, seemed very indifferent to this issue. Chinese in this part of Oregon were not only left undisturbed but also allowed to take the leavings of the white miners.

Summing up, one concludes that the agitation of the seventies and eighties against the Chinese was violent in California, spread to Washington, Oregon, and other states, and was more serious in Washington than in oregon. In oregon the most inflamed region was Portland and its vicinity. There was almost a civil revolution but the civil authorities managed to suppress it and protect the Chinese and make Portland, as well as the whole state of oregon, a refuge for the persecuted oriental workers. 
FOOTNOTES FOR CHAPTER II

${ }^{1}$ Rodman W. Paul, California Gold (Lincoln: Unirersity of Nebrasika Press, 19477, p. 50 .

${ }^{2}$ S. Wells Williams, The Middle Kingdom, Vol. II, pp. 463-574, 625-689; John Foster, American DipIomacy in the Orient (Boston, 1903), pp. 214-254; E. C. Sandreyer, the AntiChinese Movement in California (Urbana, Illinois: the University of IIIinois Press, 1939), pp. 13-14.

3 Ibid.

${ }^{4}$ Viola N. Currier, The Chinese Web in Oregon History (Unpublished master thesis, University of Oregon, Eugene, Oregon, 1928), pp. 19-20.

${ }^{5}$ Gunther Barth, Bitter Strength (Cambridge, Massachu- . . : setts: Harvard University Press, I96/), p. 136.

6E. C. Sandneyer, p. 15 .

7 Rose Hum Lee, The Chinese in the United States of America (Hong Kong University Press, I960), p. 13; Sandmeyer, p. 13 .

${ }^{8}$ Ibid.

${ }^{9}$ Mary R. Coolidge, Chinese Immigration, p. 255.

$10 \mathrm{G}$. Barth, p. 144; Sandmeyer, p. 45; Coolidge, p. 76.

${ }^{11}$ Sandmeyer, p. 42 .

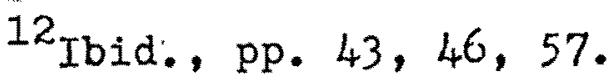

${ }^{13}$ Ibid., pp. 25, 65; Coolidge, p. 112, 115.

14 Sandmeyer, p. 43.

${ }^{15}$ Ibid., pp. 41-49; 57-59; Coolidge, pp. 61, 110, 116.

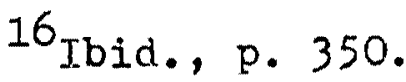


${ }^{17}$ R. D. Delmatier, C. F. McIntosh, and E, G. Waters; ed. The Rumble of California Politics, $1848-1970$ (New York: John Viley \& Sons, Inc., I971), pp. 70-71; Coolidge, p. 26i; Sandmeyer, 5.47.

${ }^{18}$ Coolidge, p. 261.

19 Robert McClellan, The Heathen Chinee (Ohio State University Press, 1971), p. 61. $20_{\text {Ibid., p. } 62 .}$
$21_{\text {Coolidge, p. } 267 .}$
22 Ibid., p. 255.
23 Ibid., p. 115; Sandmeyer, p. $65 ; \mathrm{R} . \mathrm{D}$. Delmatier,
${ }^{24}$ Ibid., p. 93.
25 Coolidge, p. 260 ; another example is given by the
author on the same page: on one occasion, one hundred and fifty Chinese landing from the Sacramento boat in San Francisco were beaten, stoned and robbed; fifty of thein injured, but no arrests were made.

${ }^{26}$ Ibid., p. 262.

27 The American Congress in 1882 passed an act prohibiting the entrance of Chinese laborers for a period of twenty years. President Arthur vetoed it, giving as a reason that the suspension of immigration for twenty years was not in accordance with the spirit of the Burlingame treaty or in accordance with assurance pledged by the United S.tates that the discretion given to that country by China would be exercised in a spirit of reciprocal, sincere and just friendship. Congress conceded the point and modified the term of years to ten.

${ }^{28}$ Calvin F. Schmid, Nonrhite Races, State of Washington (Washington State, Planning and Community iftairs Agency, Olympia, 196z), p. 20.

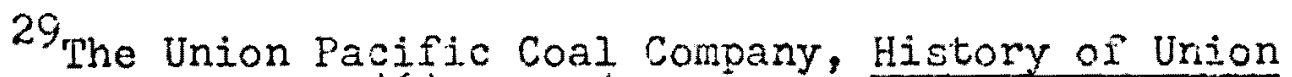
Pacific Coal Mines 1868-1940 (Nebraska: the Colonial Press, 19407, pp. 75-.101; B. P. WIcox, "Anti-Chinese Riots in 
Washington," Washington Historical Quarterly, Vol. 20 (July, 1929), pp. 205-211; 2 . Mccllellan, p. 61:

30 Edmond S. Meany, History of the State of Washington (New York: the MaCmillan Co., I909), pp. 275-277; B. P. WiIcox, p. 205.

${ }^{31}$ Ibid., p. 207.

32 Jules Alexander Karlin, "The Anti-Chinese Outbreaks in Seattle, 1885-1886,) Pacific Northwest Quarterly, Vol. 39 (April, 1948), p. 130 .

${ }^{34}$ Ibid., p. 114 .

${ }^{35}$ V. N. Currier, pp. $23-24$.

36 Hubert Howe Bancroft, History of Oregon, 1848-1888,

Vol. II, (San Francisco: the history Company, Publishers, 1888) p. 259 .

37 John B. Horner, oregon (Corvallis, Oregon: Press of the Gazette-times, 1919), p. I46.

$38^{\text {The Oregoniar, }}$ october 31,1857, p. 2, c. 3.

${ }^{39}$ Bancroft, History of Oregon, Vol. I, p. 664 .

$40_{\text {Ibid. }}$

41 Verne Blue, "Mining Laws of Jackson County, 1860-1876," Oregon Historical Quarterly, Vol. 23 (1922), pp. 138t-162.

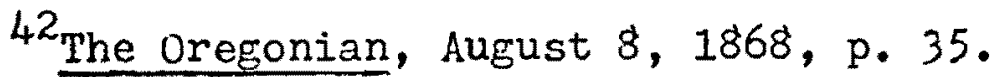

${ }^{43}$ Ibid., February 28,1877, p. 2, c. 1.

${ }^{44}$ Barth, p. 186.

45 Portland had a Chinese population of about 15,000 at the turn of the century and dropped to 2,000 in 1930's, see The Oregonian, November 1, 1935, p. i0. 
${ }^{46}$ By 1880 ther were 4,000 Chinese in Clatsop and Columbia counties alone in Oregon. This was almost 1,000 more than in all of the state of Washington, see Sam Galloway, "Rigid Tongs Blamed for Slow Adaptation of Chinese to Oregon," Oregonian, February 15, 1953, p. 28.

47 Ordinances of Astoria were particularly prejudicial to Chinese. Various ordinances directed toward the Chinese population were passed by the city council. Typical of these was a law banning the oriental custom of carrying baggage attached to a pole and numerous Chinese were arrested for violation of this law. See Emma Gene Miller, Clatsop County, Oregon (Portland, Oregon: Metropolitan Press, 1958), pp. 198-199; Lester Burrell Shippee, "Federal Relations of Oregon" Oregon Historical Quarterly, Vol. 20 (1919), p. 379.

${ }^{48}$ F. G. Young, "Why Oregon Has Not Had an Oriental Problem," The Annals of the American Academy of Political and Social Science, Vol. 34, pp. 306-310.

49 Ibid.

$50_{\text {Ibid. }}$

${ }^{51}$ Leslie M. Scott, ed., History of Oregon Country (Cambridge, Massachusetts, 1924), Vol. I, p. 19.

52 The Oregonian, March 4, 1886, editorial.

${ }^{53}$ Ibid.

${ }^{54}$ Stanley S. Spaid, "The Later Life and Actjvities of General Joel Palmer," Oregon Historical Quarterly, Vol. 55 $(1954)$, pp. 325-327.

${ }^{55}$ Harry W. Stone, "Beginning of Labor Novement in the Pacific Northwest," Oregon Historical Quarterly, Vol. 47 (1946) p. 155

56 L. M. Scott, Vol. I, pp. 27\%-279.

57 Alfred Power and Mary Jane Finke, "Survey of First Half-Centry of Oregon Hotels," Oregon Historical Quarterly, Vol. 43 (1942), pp. 264, 269. 
${ }^{58}$ v. N. Currier, pp. $43-44$.

${ }^{59}$ Ibid.

60 Ibid., August 2, 18.73.

$62_{\text {The Oregonian, August } 9,1873 .}$

${ }^{63}$ Ibid.

${ }^{64}$ Ibid., February 12,1886, p. 2, c. 1.

${ }^{65}$ Ibid.

${ }^{66}$ Ibid.

${ }^{67}$ Ibid., February 16,1886 , p. 2, c. 1.

${ }^{68}$ Ibid., February 23, 1886, p. 2, c. 1; March 3, 1886; March 5, 1886. The Chinese driven from Mt. Tabor were two hundreds in number.

${ }^{69}$ Ibid., March 17,1886, p. 2 , c. 1.

, $70_{\text {Ibid. }}$ 


\section{CHAPTER III}

STATISTICS ABOUT THE CHINESE IN THE JOHN DAY AREA, $1870--1880$

The Chinese first landed on the west coast of this country in February, 1848, when the brig Eagle brought two men and one woman to California from Hong Kong. I Subsequently, the Chinese entered the state in large numbers. To find accurate statistics in the early reconds, however, is difficult, often even impossible. Estimates of the total Chinese population in the country varied widely and usually reflected the point of view of the analyst. S. E. Woodworth, the Chinese immigrants' agent and legal representitive, claimed that only 11,787 were in California by May \&, 1852. But the state census of 1852 , on the basis of incomplete returns, estimated the number at 25,000. Another California authority felt that 17,000 was a more reasonable number. ${ }^{2}$ Dennis Kearney, leader of the anti-Chinese movement in California, estimated the Chinese population in his state at 200,000 in 1876, with 75,000 in San Francisco alone; yet in October of the same year a joint committee of Congress placed the the figure at 117,331 for the entire state. 3

Among all the documents, the Federal Goverment census is generally accepted as an unbiased and authoritative source. Yet census statistics sometimes are not helpful in some aspects. For instance, no Chinese figures can be found prior 
to the year 1860.4

The state census is more detailed, but is not a complete source eitrer, and particularly fails in recording correctily the names of the Chinese. Spelling names in English makes the attempt to identify the same person appearing ir different censuses utterly impossible. A Chinese name rendered in to English cannot carry any meaning contained in the Chinese language, except to sound strange to American ears, and to distort the Chinese connotations. A name like "Hsing" which means "new" or "happy" in Chinese, would appear in the census as "Sin" or "Sing". Since the word "Sin" was more "suitable" to describe a degraded race, many "Ah Sins" showed up in the cencus, in the places of "Ah Sings". Furthermore, eighty percent of the names were incomplete, which made the situation more confused. For example, "Chen Hsien", "Lee Hsin", and "Wang Hsing" could all appear in the census as "Ah Sin", as their family names were left out. As a consequence, some names were repeated numerous times to indicate different persons. It was not surprising to find two names exactly the same following each other closely. Contrarily, one person might appear as two different names in the various censuses. Without family names, the relationships, or kinships, such as clans, families, brothers, cousins, and generations, could not be detected.

In reference to the Chinese arrival in oregon, the Federal census does not offer any information (see Table I). 
Yet by 1860 the Chinese were already seen in oregon, as has been discussed in the previous chapter. The state census gives over four hundred Chinese in the year of 1860, most of them found at the mines in Jackson and Josephine counties (see Table II).

The Chinese influx into the state was greatly increased in the early sixties when rich gold mines were discovered in Eastern oregon. Small Chinese comrnunities mushroomed in this region, especially at the base of the Blue Mountains and in the valley of the snake River. Grant county with mining as its principal industry had the largest segment of the chinese population in the whole state in 1870 (see Table III). The main mining districts in this county: Elk Creek, Granite, Marysville, Olive Creek, Union, Canyon and John Day (the last two places located only a couple of miles frcm each other, and treaded as one area in this paper for study' $=$ convenience) each had a number of Chinese working in mines.

From the state censuses of 1870 and 1880 one finds that the chinese popuiation in some mining areas changed repidly. This change is interesting in connection with the white population which was also shifting greatly. The number of Chinese in Elk and Olive doubled between 1870 and 1880, while the number of whites declined by half (see Table IV.) The increase in the number of chinese implied great mining opportunities in this area existed for them. The deciine in the number of whites, however, meant that they were moving out 
for richer mining areas. The opposite occurred in Canyon City and Union, where the number of Chinese diminished greatly wh:le the nuraber of whites swelled tremendously. This phenomenon represented the transition of a community from mining to agricultural, ranching, lumbering and other industries, which demanded less Chinese labor than mining. In such areas the Chinese were less welcome and had to leave. This transition was exhibited in the occupation statistics in Table $v$. In the city of John Day, the Chinese grew in large numbers, while the whites grew only slightly (see Table VI.) This indicated that mining in this section was "good" for the Chinese but "bad" by white standands. The reason for the slight increase of whites in this section was probably due merely to natural increase by birth. There was also another factor in the rapid Chinese expansion in the city of John Day. They came from Canyon City where a large white population lived. Canyon City, compared to the city of John Day, was regarded in the early days by the whites as a more desirable residental district. Consequently, a policy was being carried out to exclude the "yellow peril."

The chinese usually took over the old gold mines from the whites by paying them. This worked out satisfactorily for both sides. The white made a good deal, since the gold in his property was drying up. The ionger he stayed with it, the more investment he wasted. He was in a position to desert it anyway, even if there were no Chinese arriving to 
offer hin the träde. So the white was happy that there were always enough Chinese for him to get rid of his depleted mine. For the Chinese, on the othor hand, a great rumber preferred to stay in the mountains, rather than return to cities to be persecuted. There were not as many jobs available in the mining frontiers as in the cities, therefore, they had to buy the old claims if they intended to remain. In this respect, buying up an old digging meant obtaining employment. In addition, he also got a chance to try his own fortune in business. A mine deserted by others was by no means a good one, but he could employ his patience in digging for himself. He had to shed his sweat, and the earth opened its mouth to accept it. If his luck was not too bad, he would get little reward from his labor, but by the mercy of God, the old mine would probably yield a considerable amount of the shining, yellow metal to him. Then, the dream would come true and he could at once sail back to his mome! Jobs in which the Chinese were engaging in the John Day area are comparable to those of the whites, such as physician, laborer, merchant, cook, blacksmith and so on. But the Chinese did not constitute a threat because they were in no sense real competition to their white counterparts. Chinese cooks, for example, were usually employed by American families or in Chinese restaurants. They were hired in American hotel kitchens because they could cook food in Chinese style which the Americans could not do. The fact 
that the Chinese community in the John Day area was a selfsufficient society is revealed in the wide range of their professions (Table V). The; were morchants, cooks, physicians, opium dealers, gardeners, shoemakers, barber, and so forth. All these occupations provided services to the miner and made the Chinese community almost independent in economic life. Perhaps the whites did not feel happy about this. The white merchants, for instance, might become distraught when they watched the countless "Celestials" running back and forth along the streets of the city but few were their customers. Farmers might complain that the orientals only ate imported rice and vegetables from their own gardens. Blacksmiths would not like Mongolians as they also repaired their own mining tools. Other white residents might not feel comfortable when the laundry business was monopolized by Chinese, although no one among them would care for that kind of work.

Women were few in Chinese communities, which seemed peculiar to some whites, although white pioneer communities presented the same condition. In the John Day area, the Chinese community was almost made up of males, except sixteen females listed in the two census years (Table VII). Six of them were registered as working in the "bawdy house", The author of this paper is inclined to think, like all other writers, that they were prostitutes, no matter whether they worked in bawdy houses or in wash houses. All except a few women were brought to this country, especially to the mining 
frontiers, to serve that purpose.

Beside the scrcity of the females, another special characteristic of the Chinese communities was the lack of children. Youngsters were as few as women. In John Day area, the youngest one was a boy of ten in the 1870 census. He was born in California. This gives us a clue that at least a part of the miners came from California. Whether this boy lived with his parents or his brothers, or other relatives, was not stated in the census. In other words, whether there was a complete Chinese family which included a father, a mother and the children in the area was not certain. Another boy, 9, in 1880, was born in China, and vas listed as a miner in the occupation column of the census. This is an unusual case, if the census is correct. How his father, or his relatives brought such a small boy to this courtry is hard to explain. There must have been an unusual story behind it.

Contrary to the lack of children, aged persons were in a great number. The percentage of the older age groups in these censuses were very high (see Table VII), The oldest age were 70. They still worked as miners at this old age. The median age of the entire group was 29.5 in 1870 , and 31.2 in 1880. One of the causes for such an older median age was that the male "Celestials" had not brought with them their family which would in any case lower the group's median age. The fact that the men of 1880 were older than those of 1870 is shom more clearly in Table VIII. Columns (2) and 
(4) in the table show that the older age groups in 1880 were larger in percentage than those of 1870. The largest group in 1870 was that of $21-25$, but in 1880 , it was shifted to that of 26-30. The elderliness in age in 1880 indicates that a part of the Chinese did not return to their homeland because they did not make enough money, and stayed here in the hope of accumulating a little. 
TABLE I*

THE CHINESE IN THE UNITED STATES

\begin{tabular}{l|r|r|r}
\hline \multirow{2}{*}{ The United States } & 1860 & 1870 & 1880 \\
\cline { 2 - 4 } & 34,933 & 63,199 & 105,465 \\
\hline California & 34,933 & 49,277 & 75,132 \\
Colorado & - & 7 & 612 \\
Dakota & - & - & 238 \\
Idaho & - & 4,274 & 3,379 \\
Illinois & - & 1 & 209 \\
louisiana & - & 71 & 489 \\
Massachusetts & - & 87 & 229 \\
Montana & - & 1,949 & 1,765 \\
Nevada & - & 3,152 & 5,416 \\
New York & - & 29 & 909 \\
Oregon & - & 3,330 & 9,510 \\
Utah & - & 445 & 501 \\
Washington & - & 234 & 3,186 \\
Wyoming & - & 143 & 914 \\
\hline
\end{tabular}

* Incomplete table

Source: The compendium of the Tenth Census of the U.S., 1880 (Washington Government Printing Of'ice), Tasle XiI, p.' 334. 
TABLE II

THE CHINESE IN OREGON, 1860

\begin{tabular}{|c|c|}
\hline Jackson County & 242 \\
\hline Applegate & 107 \\
\hline Ashland & 1 \\
\hline Dardavilles & 31 \\
\hline Eden & 1 \\
\hline Forrestville & 55 \\
\hline Jacksonville & 23 \\
\hline Perkinsville & 21 \\
\hline Josephine County & 127 \\
\hline Browntown & 59 \\
\hline Canyon Creek & 7 \\
\hline Galice & 12 \\
\hline Illinois River & 10 \\
\hline Sacker Creek & 15 \\
\hline Walkers Mili & 20 \\
\hline Williamsburgh & 4 \\
\hline Total & 369 \\
\hline
\end{tabular}

Source: U. S. Census Bureau, ith Census 1860, Oregon. Microfilm, V. II (746-136́I), oregon Historical Society. 
TABLE III

THE CHINESE AND THE TOTAL POPULATION, BY COUNTIES IN OREGON

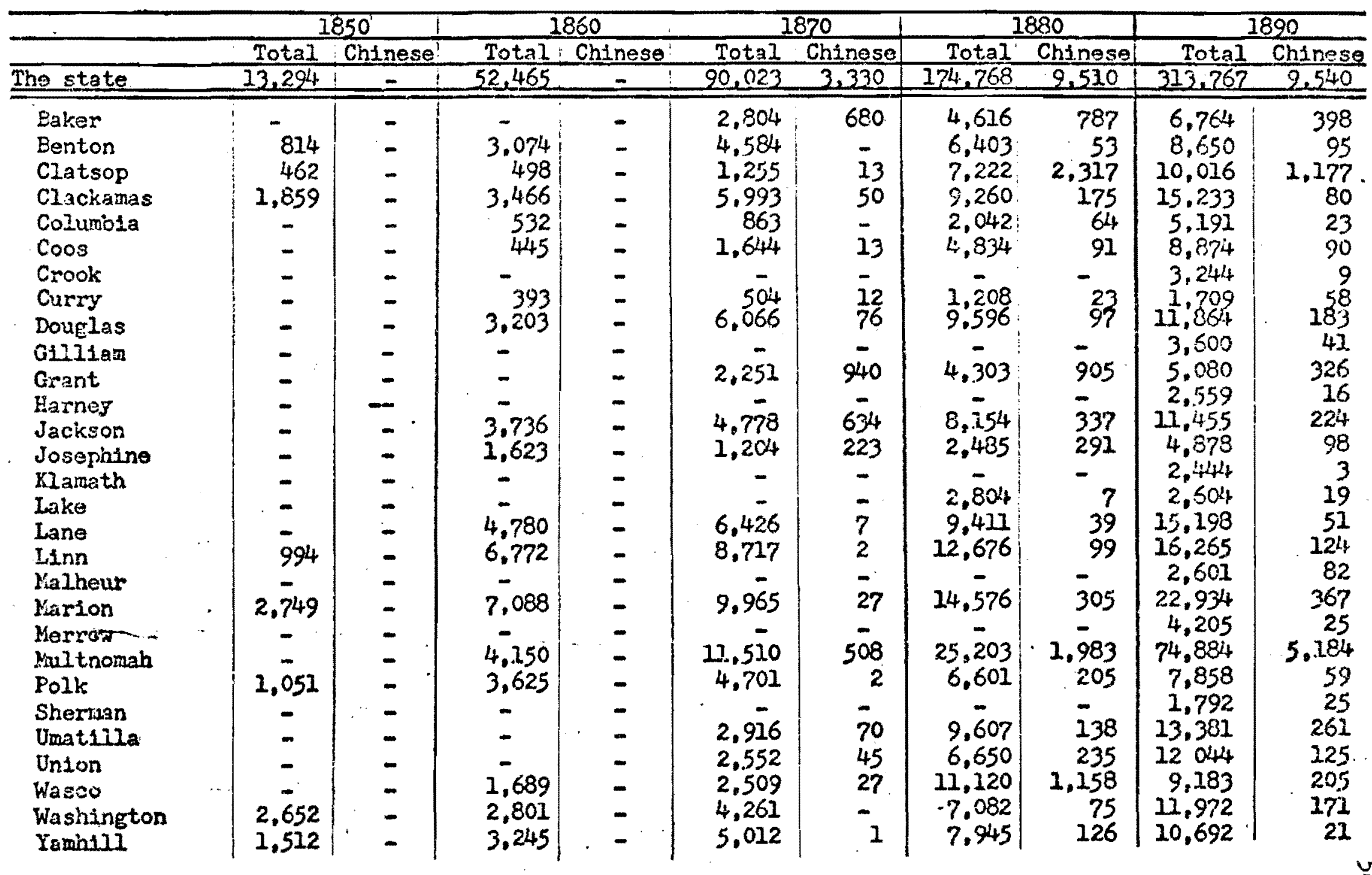

Source: The Compendium of the Eleventh Census of the United States, 1890, Part I--Population (Whashington Government Printing Office, 1892), p. 36, 521. 
TABLE IV

CHINESE AND THE WHOLE POPULATION IN GRANT COUNTY

\begin{tabular}{|c|c|c|c|c|c|c|c|c|}
\hline & \multicolumn{4}{|c|}{1870} & \multicolumn{4}{|c|}{1880} \\
\hline & \multicolumn{2}{|c|}{ Chinese } & \multicolumn{2}{|c|}{ Whites } & \multicolumn{2}{|c|}{ Chinese } & \multirow{2}{*}{\multicolumn{2}{|c|}{$\begin{array}{l}\text { Wites } \\
\text { lotal Miner }\end{array}$}} \\
\hline & Total & Miner & Total & Mner & lotal & Winer & & \\
\hline Alroid & $=$ & -. & - & - & 2 & $=$ & 148 & - \\
\hline Beaver & - & - & - & - & - & - & 215 & 1 \\
\hline Bum Run & 1 & - & 45 & 39 & - & - & - & - \\
\hline $\begin{array}{l}\text { Donder \& } \\
\text { Blitzen }\end{array}$ & & - & - & - & 1 & - & 101 & - \\
\hline Elk Creek & 68 & 64 & 43 & 15 & 130 & 130 & 20 & 11 \\
\hline Granite & 362 & 330 & 83 & 48 & 122 & 122 & 75 & 33 \\
\hline Harney & - & - & - & - & 2 & - & 147 & - \\
\hline Hay Stack & - & - & - & - & 2 & - & 190 & - \\
\hline Long Creek & - & - & - & - & - & - & 150 & 1 \\
\hline Malheur & - & - & - & - &. & - & 19 & - \\
\hline Marysullle & 25 & 24 & 102 & 37 & iे 5 & $64 \%$ & 388 & 23 \\
\hline Middle & - & - & - & - & 17 & 14 & 227 & - \\
\hline Monument & - & - & - & - & 10 & 7 & 91 & 30 \\
\hline North Creek & - & - & 49 & 1 & 3 & - & 138 & 1 \\
\hline Ol Ive Creek & 39 & 39 & 96 & 73 & 62 & 02 & 20 & 20 \\
\hline Rock Creek! & 2 & 2 & 28 & 9 & $=$ & . & 187 & 8 \\
\hline South Fork & - & - & 49 & 1 & 2 & - & 97 & 5 \\
\hline Union & 195 & 190 & 324 & $4 \overline{7}$ & $4 \ddot{0}$ & 43 & 501 & 15 \\
\hline Hinters & 1 & & 47 & 34 & $=$ & $\therefore$ & - & - \\
\hline $\begin{array}{l}\text { Upper Canyon } \\
\text { Lower Canyon }\end{array}$ & $\begin{array}{ll}n & 7 \varepsilon \\
n & 90\end{array}$ & $\begin{array}{l}52 \\
78\end{array}$ & $\begin{array}{r}183 \\
78\end{array}$ & $\begin{array}{l}34 \\
13\end{array}$ & 84 & 45 & 473 & 28 \\
\hline John Day & 85 & 81 & 184 & 23 & 357 & 298 & 201 & 1 \\
\hline Total & 940 & & $1,31]$ & & S05 & & 3,398 & \\
\hline
\end{tabular}

This and the follwing tables are derived from: U. S. Census Bureau, 9th Census 1870, Microfilm V. 1, Grant County (334-663); 10th tensus 1080, V. 2, Crant County (1-280), oregon Historical Society. 
TABLE $\mathrm{V}$

OCCUPATIONS OTHER THAN MINING IN THE JOHN DAY AREA

\begin{tabular}{|c|c|c|c|c|}
\hline \multirow[b]{2}{*}{ Occupations } & \multicolumn{2}{|c|}{$1 \quad 1870$} & \multicolumn{2}{|c|}{1880} \\
\hline & Chinese & Whites & Chinese & Whites \\
\hline Merchant & - & 11 & 9 & 12 \\
\hline Farm laborer & 7 & 22 & 12 & 54 \\
\hline Cook & 5 & 2 & 16 & 2 \\
\hline Wash house & 8 & 1 & 6 & - \\
\hline Physician & 1 & 3 & 4 & 3 \\
\hline Store keeper & 2 & - & 5 & - \\
\hline Gardener & 1 & 1 & 3 & 1 \\
\hline Bawdy house & - & - & 2 & - \\
\hline Boarding house & 2 & - & - & - \\
\hline Opiun dealer & - & - & 2 & - \\
\hline Chop house & - & - & 4 & - \\
\hline Wood chopper & - & - & 1 & - \\
\hline Laundry & - & - & 2 & - \\
\hline Blacksmith \& Tinsmith & - & 9 & 2 & 15 \\
\hline Shoemaker & - & 1 & 1 & 1 \\
\hline Barber & - & 2 & 1 & 2 \\
\hline Jewelry & - & - & 1 & - \\
\hline Gambier & - & - & 1 & - \\
\hline Restaurant & 1 & 1 & - & - \\
\hline Farmer & - & 37 & - & 38 \\
\hline loafer & - & - & 1 & - \\
\hline Wagon maker & - & 3 & - & 2 \\
\hline Butcher & - & 5 & - & 7 \\
\hline Teamster & - & 6 & - & 14 \\
\hline Stockraiser & - & 2 & - & 10 \\
\hline Driver & - & 2 & - & 3 \\
\hline Teacher & - & 4 & - & 3 \\
\hline
\end{tabular}


TABLE V

OCCUPATIONS OTHER THAN MINING IN THE JOHN DAY AREA

(Continued)

\begin{tabular}{l|cc|cc}
\hline & \multicolumn{2}{|c|}{1870} & \multicolumn{2}{c}{1880} \\
\cline { 2 - 5 } Occupations & Chinese & Whites & Chinese & Whites \\
\hline Saloon keeper & - & 7 & - & 4 \\
Carpenter & - & 4 & - & 5 \\
Hotel keeper & - & 2 & - & 2 \\
Saddler & - & - & - & 1 \\
Stone mason & - & - & - & 2 \\
Printer & - & - & - & 2 \\
\hline
\end{tabular}


TABLE VI

POPULATION AND MINER IN THE JOHN DAY AREA

\begin{tabular}{|c|c|c|c|c|c|c|}
\hline & \multicolumn{3}{|c|}{1870} & \multicolumn{3}{c|}{ Miner } \\
\cline { 2 - 7 } & Total & Chinese & White & Total & Chinese & White \\
\hline Total & 702 & 247 & 445 & 271 & 211 & 60 \\
\hline Upper Canyon & 255 & 72 & 183 & 86 & 52 & 34 \\
\hline Lower Canyon & 168 & 90 & 78 & 91 & 78 & 13 \\
\hline John Day & 279 & 85 & 184 & 104 & 81 & 23 \\
\hline & \multicolumn{7}{|c|}{ Population } & & Miner & \\
\hline & Total & Chinese & White & Total & Chinese & White \\
\hline Total & 1,115 & 441 & 674 & 393 & 364 & 29 \\
\hline Canyon City & 557 & 84 & 473 & 73 & 45 & 28 \\
\hline John Day & 558 & 357 & 201 & 320 & 319 & 1 \\
\hline
\end{tabular}

TABLE VII

THE CHINESE IN JOHN DAY AREA

\begin{tabular}{|l|c|c|c|c|c|c|}
\hline & \multicolumn{3}{|c|}{1870} & \multicolumn{3}{c|}{1880} \\
\hline & Total & Male & Female & Total & Male & Female \\
\hline & 247 & 239 & 8 & 441 & 433 & 8 \\
\hline $\begin{array}{l}\text { Upper } \\
\text { Canyon }\end{array}$ & 72 & 66 & 6 & 84 & 79 & 5 \\
\hline $\begin{array}{l}\text { Lower } \\
\text { Canyon }\end{array}$ & 90 & 88 & 2 & & & \\
\hline John Day & 85 & - & & 357 & 354 & 3 \\
\hline
\end{tabular}


64

TABLE VIII

AGE STATISTICS OF THE CHINESE IN THE JOHN DAY AREA

\begin{tabular}{l|c|c|c|c}
\hline \multicolumn{2}{c|}{1870} & \multicolumn{2}{c}{1880} \\
\hline Average age & \multicolumn{2}{|c|}{29.5} & \multicolumn{2}{c}{31.2} \\
\hline & Total & Per (2)ent & Total & Per (4)ent \\
\hline 20 \& under & 31 & $12.6 \%$ & 47 & $10.1 \%$ \\
$21-25$ & 63 & $25.6 \%$ & 82 & $18.6 \%$ \\
$26-30$ & 59 & $24 \%$ & 118 & $26.1 \%$ \\
$31-35$ & 37 & $15 \%$ & 82 & $18.6 \%$ \\
$36-40$ & 28 & $11.4 \%$ & 57 & $13 \%$ \\
$41 \&$ up & 28 & $11.4 \%$ & 55 & $12.6 \%$ \\
Total & 247 & $100 \%$ & 441 & $100 \%$ \\
\hline
\end{tabular}


FOOTNOIES FOR CHAPTER III

$1_{\text {Rodman W. Paul, "The Origin of the Chinese Issue in }}$ California," Mississippi Valley Historical Review, Vrl. 25 (September, 1938), p. 18:; Viola $N$. Currier, The Chinese veb in Oregon History. (an unpublished thesis, University of Oregon, Eugene, Oregon, 1928), p. 16.

2 Rodman W. Paul, The origin of the Chinese Issue in California, p. 183.

${ }^{3}$ Robert McClellan, The Heathen Chinee (Ohio State University Press, 1571), p. 5 .

4 The number of the Chinese immigrants before 1860 were recorded by $V$. N. Currier as follows: in 1849, seventy-four were listed; in 1850, 4,918 men and women; in 1852, 11,026; in $1854,13,000$; between 1854 and 1860 , the annual rate was 3,000. (See Currier, Chinese web, pp. 16-19.)

In Union the white occupations were: 38 farmers, 10 farm hands, 14 miners, 10 stockraisers and butchers, 6 wood choppers, 6 blacksmiths, 1 doctor, and so on. This list is very similar to that in John Day area.

6 The figure of the year of 1880 might be an underestimate, considering the number of the Chinese physicians available to Chinese miners at the time. There was one physician in 1870. with 247 Chinese. If the area had had sufficient business to maintained four doctors in 1880 , then, it can be interpreted that the Chinese there were higher in number than the statistics of the census gives.

${ }^{7}$ Some of the evidences are the accourt books and the payrolls found in the Kam Wah Chung Co. building at John Day. 
THE FORMAIIIN OF A CHINESE COMMUNITY

"Chinamen" in this land were known for their clannishness and gregariousness; for wherever there were considerable numbers of Chinese there existed also a Chinatown. It was quite true that they were clannish, as we have noted in the previous chapter. But it was not necessarily true that they were gregarious. Many Chinatowns might not have taken form. In fact, a Chinatown was a product of segregation caused largely by whites. Anyone who has visited a Chinatown in any city must be impressed by its bad envirorment and naturally concludes that Chinamen are really a debased people and are only fit to mix with criminals, drunks, and prostitutes. Actually, though, this situation was a result of segregation by whites.

In the John Day area, the Chinese at first lived in at least at two locations--John Day and Canyon City. They were eventually compelled to move out of Caryon City and concentrate at John Day. Law was the dread weapon used by the white to "round up" the dispersed Chinamen to a certain smali area. For example, the Grant County News of February 12, 1885, recorded:

A Portion of Chinatown Reduced by the Flamesm-It Vill Not Be Rebuilt.

Shortly after $120^{\prime c l o c k}$ last Friday night the dread cry of 'Fire! Fire!' was heard on the streets, and a general rush and excitement foliowed. The scene of the fire was soon ascertained to be in Chinatown, 
which caused many a property holder to heave a sigh of relief.

- In a short time a second alarm was sounded. The fire had been deserted too soon and it broke out again vith redoubled force. The buildings that had been torn down were now wrapped in flames, and fears were entertained that the conflagration might extend to other portions of the town. . .

of course it was impossible to ascertain the cause of the fire, as the chinamen were very reticent on this subject. .

The Chinamen will not be allowed to rebuild on the former site, and several of them have already left town and located at John Day, which is a matter of but small loss to the town.

Obviously, "the Chinamen were very reticent on this subject" already gives some hint that they knew who set the fire, but dared not to speak out. Thus, an "act of God" and the acquiescence of the white community soon forced the removal of the Chirese from Canyon City.

Chinamen were not allowed to enter into a community and settle down without the permission of whites. An incident in Great Falls, Montana is a good example of this.

The news spread like a prairie fire that a pig-tailed Celestial had planted his wooden-soled shoes upon the sacred soil of Great Falls. .... That same evening a meeting of the local labor leaders gave vigorous and unanimass assent that there would be no Chinese laundry in Great Falls because, as everyone knew, to allow one of his race to enter was to open the gates to all. The bewildered vistor was arrested amidst a howling mob and carried to the edge of town, where he was sent on his way with appropriate ceremonies.

The Tribune concluded the next day that "there is no room for the almond-eyed sons of china in this city. no pig-tailed saffron will be allowed to call this city his home. 2

"The incident in Great Falls," continued the same writer, was typical of town after town in the West and also in the 
East, where violent prejudices often produced violent action similar to the beating of a Chinese laundryman in Washington, D. C."13

In 1861, the lure of yellow metal attracted at least 4,000 persons to Auburn, in Baker County. At the end of that same year some 3,000 had gone to the Boise gold fields in Idaho because the gold played out. "A meeting was held about this time and it was decided to allow chinese to labor in the mines. Eventually the city of Auburn was inherited by the meek, pig-tailed Orientals." 4 under the same circumstances the Chinamen were allowed to come to John Day area, which is close to Auburn, to buy out the "dead" mines from the white. The segregation from whites was accepted tacitly by Chinese, for it also served their needs, particulariy the need of safety. Coming to a hostile land, separation from their race meant danger; staying together brought the feeling of security, although not necessarily real safety. At a time when Chinese were killed like wild dogs at their shacks, camps, and stores, no one but those with brave heart dared to live among the whites. The threat of being attacked by Indian tribes in the mountain area, the lawless conditions on the frontiers, and the menacing attitudes of the white workingmen in the urban districts would all cause the little sons of Confucius to tremble together. Above all, the contempt held by average whites tcwards them would alone keep the sensitive Chinese from approaching whites. 
A number of indigenous Chinese factors also contributed to the existence of Chinese communities. First, almost all Chinese were related, either by blood or by "Iand". Half of the Chinese in John Day area had the identical family name "Ing" (任). This shows that they came, most likely, from a same clan, or more properly to use chia-tzu, a Chinese term for clan. While those non-Ings were possibly either the Ings' maternal cousins, or otherwise related. Still some others were "tung-hsiang" (同楖)--people from the same region. An old saying goes like this: "Although our blood is not close, our lands are." (人媇累境) This phenomenon of "Tung-hsiang" provided social unity for the chinese, for example, the Chinese benevolent societies today are organized on this basis. Sometimes, men with different family names could also be traced to the same original ancestry. Sometimes, as in the case of an historical event, people with different last names such as

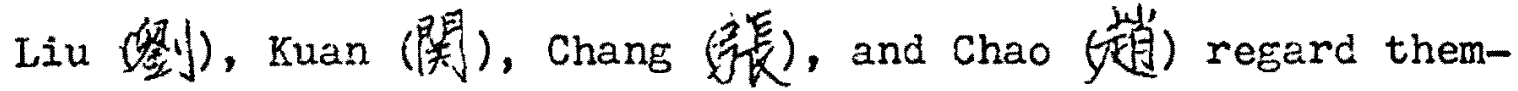
selves as brothers. By taking an oath in front of a Buddha and performing a certain ritual, or even simply by pointing to the Heaven and the Earth as the withesses, people could also become brothers. Tong associations were formed this way. 5 People united like this sometimes maintained a relationship closer than that of real brothers. In these ways, the people in a smail conmunity like that in John Day might all related. This, of course, helped them to cling to one another. Secondly, the Chinese laborers were almost all male and 
without family. As bachelors their need to live together was much greater than that of men with families. Restlessness and the feer of being alone are grent forces that drive bachelors to seek company. Living in a totally strange land, their loneliness and homesickness were much greater than they could endure, and, therefore, they craved for life among their kind.

On the other hand, it would have been easier for them to be separated from each other, if their families had been living with them. A family needs more privacy than an individual, and the distance between families was usually greater than between individuals. Again, families will not get along as easily as incividuals, even if the families were related. And if a family lacks governing power from elders above, the families of the younger generation, such as those consisting of brothers and paternal cousins, were not held together. In China, sometimes brothers' wifes were strong enemies and caused great families to break up.

Children were also important in bringing families out of ethnic communities and into native society. Children have a tendency to disperse. They are not satisfied in the isolated shell of their parent's home. Besides, Chinese parents usually put thier children's education and future in the first place, which makes them willing to live closely with whites. Since there were not so many females and children to break up the group, Chinese laborers in the Chinese 
communities stuck together tightly.

Thirdly, Chinese laborers in America vere travelers, and not permanent home-seekers. With a firm desire to go back to their birthplase in mind, their stay here was only scheduled as a temporary arrangement. On the whole they hoped to return immediately by working hard for a couple of years, or at most five years or so. If some of them had thought that they were not to see their homes again, they would not have come at all, even if it meant starving and perishing at home. An observation made by Walter $\mathrm{H}$. Mallory, about a large group of Chinese who migrated between Shantung and Manchuria, fully illustrated this phenomenon.

There is an annual movement of labor from Shantung which reflects to a marked degree the love of home and unwillingness to leave it for new fields. Every year more than thirty thousand men migrate from Shantung to Manchuria. They leave early in the spring and travel more than 500 miles to the rich lands of the north where they work during the summer; but in the autumn they all return to their homes in Shantung. In the days before the construction of the Peking-Mukden Railway, they made this trip on foot taking nearly a month on the road each way. It is almost unbelievable that such a practice continues year after year when good Manchurian farm lands are available and can be bought on easy terms and for a phenomenally low price from the railway authorities wich are making an effort to settle this region. It cannot be said that the people do not realize the benefits, for they see them with their own eyes and share in them for a short time every summer, but they are untilling to change their homes and their mode of life.

Manchuria is close to Shantung and can be considered a neighbor province, yet Shantung folks would have rather wasted their time, money, and energy on anmal migration, no matter 
how profitable it would be to settle permanently in Manchuria. Chinese, on the whole, could be called the "salmon" of mankind. Anxiously, the Chinese laborer hoped to return, since he was struggling in a totally alien land. The goals of his stay here were purely economic. In order to shorten the time of detention here, he would like to earn every cent he could and save every penny he could. Because of this, he had no desire for a long-range goal to achieve greater or more rewarding jobs, which would unavoidedly involve more training, and thus prolong his return. Therefore, he was not interested in learning American techniques, customs, and the way of life. The prerequisite to long range success in America was understanding the language, which he fully believed it was impossible for him to achieve. Why not then, spend off-work time in cheerfully chattering with fellow-countrymen in the Chinese comanity?

Fourthly, to live in the chinese community was to ensure job opportunity. "Culture shock" is a modern term to explain the common confusion of the foreign student, who, despite good language training, as well as other adequate preparation, still finds himself unfitted for life in a new country. Thus the confusion of Chinese laborers upon their arrival and stay here must have been tremedous. They were totally lost in America. Their abilities were paralyzed. All they ould do was stay and wait in Chinese communities, and let their fellow-countrymen, who had been here earlier 
and had gained much experience, help them and furnish them with news about jobs opportunities.

The jobs they engage: also contributed to their segregation. Except for demestic work, all jobs for which they were eligible were prjmarily menial, team jobs, such as railroadconstruction, dam-building, tree-cutting, ditch-digging, crop-harvesting, etc. Therefore, an unskilled team laborer, if left his group, would hardly be able to find a job. It was obvious that in order to get employment, he had to live among his group. So it was also obvious that the employment engaged, would, in turn, make him stay within his conmunity. Finally, living together also helped him to save money. Rooms and appliances could be shared. And shared food would surely be better and less expensive. Time could also be saved by sharing the cooking and shopping.

To sum up, the segregated existence of Chinese communities in the United States was caused by both the discrimination and restriction of whites, as well as by the needs of the Chinese, and not just because Chinese were such a clannish people, unpenetrable and impossible to be assimilated, as many whites alleged. It is fair to say that the segregated Chinese communities were designed initially by whites, and that the Chinese, consciously and unconsciously, accepted them passively. They took it as an "Indian reservation", and utiljzed it as a base for survival. For the Chinese, the disadvantages of living closely 
in the small communities were also many. Some of them were: (1) Concentrating in certain areas made the small groups seem comperativly larger, and gave provincial-minded natives the wrong impression that there were foreign "nations" within their cities. For example, the newspaper Weekly Missoulian complained in February 28, 1878 , that the Chinese converted "into a little strip of Asia" whatever territory they occupied; "Into that strip our laws or our constitutions cannot enter. Shall we continue to invite this tapeworm into our entrail?"7 Thus, the Chinese were more vulnerable to assault as a group than as separate individuals. (2) Confining themselves to their own small communities cut them off from the main stream of the outside world, and reduced their opportunities of contact with the white, and the chance of mutual understanding. (3) Their provincialism also limited their business chances and abilities. Consequently, they rarely expanded beyond grocery stores and restaurants. Living together provided bad elements an easy opportunity to live as parasites on others. Opium dens, gambling houses and brothels all flourished. (5) Conflict grew out into small areas, the competition for similar jobs and the resulting limitation of resources. The notorious Tong wars were one consequence which also damaged the reputation of all Chinese. In the John Day area the Chinese community was a typical miners' center and was quite large in size at first. One writer estimated, "Gold was discovered on Canyon Creek 
in 1862, and soon 10,000 people, half of them Chinese, were crowded into the narrow little canyon." 8 Five thousand Chinese, or "half of them" seems too large a number. One fourth, or perhaps 1250 seems a more reasonable number. Anyway, we can guess that at the beginning at least one thousand Chinese came to the canyon.

. They came mostly from California. A pioneer of Eastern Oregon wrote, "In 1862 gold was discovered near Canyon City. Imnediately heavy traffic developed from California and Nevada mines to the John Day 'diggin's'."9 This indicates that the miners, including the Chinese, came by land. But many Chinese also came by sea. From San Francisco they came by boat to Astoria, Portland, and then to The Dalles. There was wagon traffic from The Dalles to John Day. But since the Chinese were poor, they usually walked to the Canyon, covering the 225 miles with their simple personal belongings carried on a pole across their shoulders. 10

The gold deposit in this area, like that in Auburn, soon played out. The white Argonauts immediately moved on to other, richer districts. By 1870, there were only 57 white miners counted in that year's census. A great number of the Chinese also left. But a few hundred still lingered on. In the 1880's there arose another wave of anti-Chinese feeling across California and along the Northwest coast. This strongest wave of riot sent more-terror-haunted Chinese to the Blue Mountain regicn. Thus, from the 3860 's on, there 
was a considerably large sized Chinese community in the John Day area.

The Iife of this group of Chirese miners, as that of the majority of Chinese laborers in this country, was unknown to the outside world. Fortunately, a Chinese grocery store building is still miraculously standing in John Day where it had been built one hundred years ago. A number of articles, still inside the buildings shed some light on the life of this forgotten minority. 
FOCTHOTES FOR CHAPTER IV

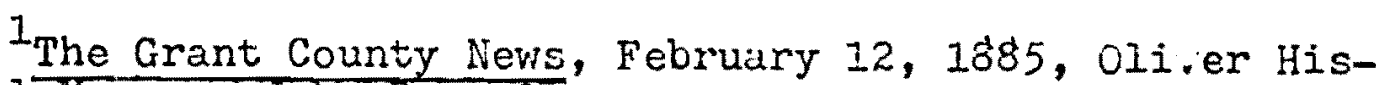
torical Wuseum, John Day, Oregon.

${ }^{2}$ R. McClellan, The Heathen Chinee, p. 4.

${ }^{3}$ Ibid.

4"Auburn--A Ghost Gold City of Oregon," The Sunday Oregonian, November 5, 1933.

5 "Tong" in Chinese is the word for "party", "clique", or "a gang", and indicates that it is an organization for the purpose of political strife or rebellion. The greatest rebellion in Ching dynasty was the Taiping Rebellion, 1850-1864. After being defeated, its remainders scattered as many under-ground masonic organizations.

Many Chinese laborers in America perhaps were the membors of the Taipings, and carried Tong organizations to this country. But as the oreginal goal of throwing over the Manchu regime no longer existed, the Tong societies thus gradually modified to be either the associations of defferent region or district, or of tiny groups of a few persons. ConsequentIy, the conflicts or wars between different gioups in the Chinese communities were all called Tong wars.

Galter H. Mallory, China: Land of Famine (New York: American Geographical Society, 1926), pp. 19-20.

7Larry Đ. Quinn, "Chink Chink Chinamen," Pacific Northwest Quarterly, Vol. 58-59 (April, 1967), p. 86.

8 Register-Guard, Eugene, Oregon, November 19, 1967, Cregon Historical Society.

${ }^{9}$ : A. Long and R. R. Jackman, The Oregon Desert (Caldwell, Idaho: the Caxton Printes, s, Ltd., I964), p. 34.

${ }^{10}$ Interview with Bob wing--Doc Hay's nephew, 1023 SE 21 Street, Portland, Oregon, February 25, 1972. 


\section{CHAPTER V}

\section{THE KAM WAH CHUNG COMPANY AND THE LIFE OF THE CHINESE IN JOHN DAY AREA}

of all the structures in the John Day Chinese community, the building of the Kam Wah Chung Company is the only relic left in today's John Day Park to indicate that once thousands of Chinese lived there.

The main part of the building was probably constructed In 1866-67, four years after the discovery of gold in the John Day region in 1862. A wooden attic was added to it in the $1890 ' \mathrm{~s}$, and a northern wing was built in about 1.917-18. ${ }^{1}$ The whole building, except the upper part, was constructed with large sandstone blocks which were taken from the canyons, tro miles to the south. The size of the stones range from one to two feet long, and more than one foot wide. The walls are thick and the windows are few and small. The front door is heavy and iron-plated. When the door is shut the whole building resembles a castle. It seems to be of very strong and unbreakable construction, and must have given the chinese occupants the feeling of security during the troubled days.

The building, with its unusual. appearance different from the others, has also a look of mystery. Feople might quite naturally have thought to themselves: "What are those heathens doing inside? Are they performing some peculiar ritual? Are they gambling, or even doing something sinfal?" 
One can see the sane style of stone houses along the south coast of China. However, they do not have an iron door and are of much finer quality and architectural structure. It seems that the builders, while using the cheap and availablè material at their disposal, set up the house, not only for the purpose of protection, but also to follow the traditional practice.

The owners, or the builders, who constructed such solid houses like the Kam Wah Chung Company, instead of the common shaky camps in mining areas, indicated that they did not intend to be temporary dwellers. This appears to be something of a contrast to what has been discussed so far--that the Chinese would not settle down anywhere other than their homeland, that they came here only with the purpose to earn a little money and then return immediately to China, and that they were not interested in anything associated with long range goals. To the great number of them this was absolutely true, but there were some exceptional Chinese who were very ambitious, less home-oriented, and would likely settle down here on a permanent basis, which, however, did not imply that they would not go back in their old age. Examples are found among the Chinese ir Southeast Asia, who returned to China, leaving behind all their great enterprises, to spend their retiring days comfortably in their old homes.

The construction of these buildings for permanent rem sidence reflected another spectacular thing: the favorable 
situation for the Chinese around 1866--the great demand for their labor in railroads and other industry; the failure of the anti-Chinese issue to spread from California; no serious depression in the West; and the Burlingame Treaty of 1868 that stipulated the Chinese in the United States were to be afforded protection similar to that extended to America citizens. Above all, the gold in this district still continued to yield considerably; by 1872 twenty-six million sollars worth of gold had been mined. Things looked bright, and a active Chinese community was already formed.

There were some other stores in Chinatown. At least two other companies, See Ling Co, and Quong Yuen Lung Co., are found in both the early local newspaper and the Chinese letters in the building. 2 only Kam Wah Chung Company has survived. It maintained its business as late as 1940 when its able manager, lung on, died. Then the store functioned mainly as a herbalist's office by Doc Hay--On's partner. In 1952, when Hay died, the building was closed.

The Kam Wah Chung Company was primarily a grocery store, and was the essential part of the Chinese community in the John Day area. Owing to the different food habits, and different metrod of cooking, Chinese usually prefered to buy Chinese groceries. Therefore, wherever there is a chinese community there must be at least one Chinese grocery store.

Many of the foods the Chinese used to eat were not available at white men's markets, and alnost all items they saw 
there were strange to them. To buy food never before tasted was certainly unwise. Besides, only few of the chinese lahorers had the ability to read the food label marked with prices and names in English, nor could they talk freely to the white store keepers.

On the other hand, they knew everything at a Chinese grocery store. They could figure out the exact flavor of the food. They could calculate how much rice lasted how many days. Most important, he could bargain with the storekeepers, and even could negotiate credit arrangement.

Food habits were another important element affection one's shopping behavior. What the white liked the best the Chinese disliked the most. Beef, milk, butter, and Cheese, the white's favorites, were seldom eaten by the populace in China, especially the Southerners. Oxen and cows were so important for farming, peasants looked upon them as benefactors, and seldom killed them for food. The Cantonese might. crave some dog meat, which they called "fragrant meat," but not beef. As a matter of fact, the sinell of beef to many farmers was intolerable.

The Chinese laborers in the United States must have acted similarly. If they were able to eat chinese style food, their chopsticks would probably not touch others, no matter how good. Therefore, it is understandable that the Chinese were accused of having never purchased goods from whites. This was not the fact. Chinese laborers were the chief 
consumer sometimes. In an article in the St. Helens Sentinel Mist, Pearl Becker, an old resident, remembers:

When iny grandparents came to Jregon in 1877 , twere was a work camp of Chinese laborers near Rooster Rock. - . They would buy poultry, eggs, butter, small pigs and other farm products. They were very fond of white ducks, and would buy all my Grandmother could raise. 3

An excerpt from the Walla Walla Statesman of March 15, 1865 reveals more explicitly the contribution of the Chinese miners to the local economy.

Colville feels the loss of her Chinamen, they having been the principal consumers of her productions. They worked and took out money on the Columbia and Pend oreille rivers, where white men would not work, and every dollar they made was money put into circulation, and the benefit of which would never have been felt had it not been for them. It is hoped that since the China Poll Tax has been reduced that they wijl return." 4

The "Chinamen" in John Day area were also the principal consumers of local products, at least that was the case before the Kam Wah Chung Company was established.

The date of the establishment of the company probably was about at the same time as the building was erected in 1866-67, but was registered officially in the year of 1871 . A commercial pen used by Bob Wah--Hay's nephew-is found with an advertisement for his business, which says "BOB WAH, Chinese Medical Herbd, Established 1871; 210 N. W. Canton St., JOHN DAY, ORE., Phone 68." Again, there is a business paper that bears the year 1871 as the establishirg date (see Fig. 6, page-177). 'The company!s formal advertisement for business is found in the Grant County News of December 15, 1883. It 
reads:

Kam Wah Chung, contractor for Chinese labor. Laborers of all kinds furnished at short notice. John Day, Oregon.

In 1886, the company was purchased by Lung on and Doc Hay, who orned the company in partnership until their deaths. 6 Lung on himself told a newspaperman that he went to Canyon City from San Francisco before President Benjamin Harrison was elected in 1888 "for the purpose of getting gold out of the earth." 7 Hay probably arrived from eastern Washington Territory, earlier than lung on, as many of his relatives still remained there. ${ }^{8}$ Meantime, along with these two inen: came many other Chinese from the west Coast, particularly the Northwest, in order to avoid the "white peril" of that period. Kam Wah Chung Company, under the management of Lung on, took a giant step to expand business to the white residents. The Chinese population though fairly big was not large enough to support many. Chinese grocery stores in this small area. This assumption was based on business advertisements of the Kam Wah Chung Company, which were all printed in English; the only purpose of the advertising was thus certainly to draw the attention of whites.

One of the advertisements in the year of 1894 used "Japanese Goods" as their head line ona business paper (see Fig. 7, page 178). This was an unusual phenomenon, probably attributable to new attacks on the chinese. The distress of being persecuted was not alleviated in the nineties. The 
flood of white hatred in the seventies and eighties received a fresh impetus in 1891 when Thomas J. Geary, Representative from California, submitted a bill in the House reaffirming the provisions of the old Chinese Excludion Act of 1882 and adding a few new ones.

The Geary Act of 1892 provoked a debate which marked a high point for Chinese exclusion agitation in $1890 \mathrm{~s}$. The new Act required that all Chinese in the country register and submit to identification procedures, including photographing, or suffer the penalty of imprisonment and deportation. In defense of the bill Geary frankly described the Chinese as "undesirable", accusing them of working for as little as five dollars a month and living on six cents a day. The Chinese would degrade our civilization because a Chinese laborer did not bring any wife or children with him. He did not set up a family but acted only in his own interest. . . Nothing should stand in the way of exclusion. 9

To insure the Geary bill's passage in Congress, a series of out rages against the Chinese took place in the West, including oregon. To prevent a repetition of the mid-eighties' tragedy, President Cleveland sent advice to Governor Pennoyer of oregon on the course to pursur so to protect the Chinese in the state. In his answering telegram, Governor Pennoyer asserted, "It you will attend to your business, I will attend to mine."10 This telegram made him a nationwide figure. Pennoyer held the governor's position as late as 1895, and held the office of Portland mayor from 1896 to 1898 .

In this adverse atmosphere, Kam Wah Chung Company must have had difficulty in seliing Chinese goods to whites. As an alternative, the term "Japanese Goods" was borrowed to serve as a ruse for selling Chinese products. By 1894, the 
rate of Japanese immigration to the United States was still quite low and the Japanese had not provoked much sentiment against them. Instead, emerging as a new world power in the Far East, the Japanese attracted attention as well as admiration from trie people of America.

hovever, after 1894, "Japanese Goods" were no longer used; in their place was "Chinese goods of all kinds." This indicated that the residents' interest began to return to the Chinese products. Or more accurately the patriotism of the management of Kam Wah Chung Company was awakened by the SinoJapanese War of 1894-95 and that feeling made these Chinese abandon using the name of an enemy nation for business purposes, even at the risk of losing money. (Chinese immigrants were noted for their patriotism. Many receipts for the donation from the Kam Wah Chung Company to Chinese government are found, one of them is given on page 181 as evidence.) To their surprise, business was getting better and better until it reached its "zenith" from 1897 to 1910, especially from 1904 to 1906.11

The relatively prosperous business of Kam Wah Chung Co. was due to the changing conditions which seemed favorable to the Chinese: (I) The relief of the tension on the part of whites toward the Chinese as the influx of the "yellow peril" to this country was effectively checked by the Geary Bill, making the natives tolerate the Chinese without disturbing them for a while. (The Chinese in the United States numbered 
107,458 in $1890,89,863$ in $1900,71,531$ in 1910 , and 61,639 in 1920.) (2) The Japanese immigration, on the contrary, was increasing so rapidly that by 1906 about a thousand Japanese a month were puring into the U. S. Many people were alarmed. The Californians were particularly anxious to halt the inflow. The "blunder" they made was the "Japanese school-boy crisis" of October, 1906, which almost brought the United States and Japan into war. ${ }^{12}$ Thus, the anti-oriental attention focused ori the "Japs", and the "Chinamen" were forgotten temporarily. ${ }^{13}$ (3) The transition from frontier economjcs to advanced farming, ranching, and other industries in eastern oregon made more jobs available to the Chinese laborers. (4) The mining enterprise in this district boomed again in the late 1890's and early 1900's. According to the Blue Mountain Eagle, the output of gold and silver in Grant county in 1898 was $\$ 176,231,82$ and increased to $\$ 303,680,53$ in 1899 . In the early 1900 's good new mines were discovered on the western slope of. the Blue Mountains--in the vicinity of Granite, Susanville, Prairie and Canyon City. ${ }^{24}$ It was only after 1907 that the production of ore, especially of gold, dropped. ${ }^{15}$ As a result, the Chinese community at John Day gradually declined.

During this period of prosperity, the Kam Wah Chung Company distributed a great variety of stylish and coiorful business cards for their customers. Many of then dated from 1910 to 1935 were still left in the building. They imply that that the company endeavored to sell goods to the white 
inhabitants, as the Chinese in this area were greatly reduced in number. In fact, the company was still very aggressive in expanding its business after the decline of the chinese community. In the early $1930^{\prime} s$, the company acted as a chevrolet agency, selling automobiles to the white residents. The company also did some remarkable things to promote their business, such as first to istall a telephone and use electricity. The other residents and businessmen in this area followed this examples. 16

The company had a great variety of merchandise to offer. Candy, cigarettes, Manila tobacco, havana cigars, and matches were carried in large quantities. Supplies also included rice, cotton and silk cloth, fire crackers and other Chinese items. Needless to say the Chinese herbs were fully stocked. Opium was also available. Judging from the large quantities of the goods left in the building, the business must have been on a whoiesale basis, as well as retail. : Nany orders came from Chinese grovery stores in the towns of Baker City, Susanville, Mt. Vernon, and Prairie City, as indicated by the business letters.

Some luxurious merchandise such as sandalwood fans and swallow's nests were also found, which showed that some peopie here, if only a few, could afford to buy these luxury products. If a report that the largest lump of gold, worth of $\$ 100,000$, was iound in this district by an Oriental is not false, then there must have been some chinese who had struck their fortune 
from the earth. ${ }^{17}$

The goods sold, including the herbs, were purchased from San Francisco and Portland; the invoices are predominantIy from these cities. Others goods were secured from Seattle, St. Louis, Chicago, as shown by the invoices. Still other business transactions originated in Canton and Hong Kong. Opium and opium pipes, which are still to be seen on the table in the central room of the building and are of particular interest to today's visitors, undoubtedly came from China. The pipes are made of bamboo; the carving is delicate; the surface of the bamboo is smooth and shiny. The cans of opiun have Chinese labels with the names of ships--those ships on which the opium was shipped to America. Some of the names included "Siberia" and "Manchuria" were American ships belonging to the Pacific Mail S. S. Co. ${ }^{18}$ Since all the opium cans bear the register labels, the opium used at this company was not smuggled from China. Some opium, surprisingly, was even purchased from American stores. One of the company's commercial letters, reads in part:

$$
\begin{aligned}
& \text { SPOKANE DRUG CO. } \\
& \text { WHOLESALE DRUGGISTS } \\
& \text { SPOKANE, WASH. }
\end{aligned}
$$

Mess. Karn-Wah-Chung \& Co.,

Nov, 13,1903

John Day, Ore.

Gentlemen:-

We send you 2 Ibs. Gum Opium to-day registered mail at the price we quoted you, $\$ 3,90$ per pound. (See Appendix E for the complete letter.)

Aside from its main function as a grocery store, the 
Kam Wah Chung Company also served many other purposes. It acted as a labor contractor as shown by its ads in the local newspaper. Around the company there must have been many "Chinamen" waiting for employment, who were either unemployed or labored at their own old placers but were more willing to be hired.

It has been noted that the Chinese usually liked to buy the "worn out" mines from the white. Some of these mines might turn out to be still good and worthy of digging for a while. Others were as worthless as a pile of sand. By and large, their mining business was not profitable. As time went by gold dust became scarce; and even diligent and patient workers like the Chinese laborers could hardly make a living from it and much labor was wasted. They would have preferred to leave for other jobs, if there had been opportunities; yet often they were compelled to keep mining, for it was the only job available to them.

Becalise of the depleted mines the Kam Wah Chung Company was able to advertise "laborers of all kinds furnished at short notice." The compary could be more informative than the individual in finding job opportunities by virtue of its commercial contacts with the whites, and also by the better language ability of the people in the company. Therefore, it acted as an employment agency for its countrymen.

The company itself also omed, or shared with miners, some gold mines. A time-sheet book for $1888-1889$ of a gold 
mining company named Chu Li Po was found amony the records, with twenty-six miners' names in it. It was most likely a branch enterprise of the Kam Wah Chung Company.

The company also served as a recreation center. A number of newspapers, magazings, novels, texts of opera, chess and checker sets were found in the building. Musical instruments were many; a huge loud-speaker, a phonograph, and many records from Hong Kong and Berlin ${ }^{19}$ indicated that people here made an effort to break their loneliness in suitable ways. Gambling devices and lotteries, of course, were also found in the building, revealing the Chinese weakness for gambling.

Besides gambling and the other refreshing activities, many people must have also enjoyed reading and writing. There are collections, in the form of books, of hand-written poems. Undoubtedly someone must have worked on it patiently and painstakingly, while his fellow countrymen were involved in the exciting gambling. Another amazing finding is that many chinese here were literate unlike many of their fellow immigrants. Many letters left in the Kam Wah Chung building were the works of various persons. Probably nany of them acquired literacy in America. The traditional prestige held by intellectuals in Chinese society urged them to learn as did unhappy experienca of being unable to correspond with their loved ones in China. The letters are the most valuable articles found in the building. fritten records of chinese laborers are rare, those at John Day are a unique find and cast considerable light on 
the life of this group people in the united States.

What is regretable is that the writers of these letters seldom gave a detailed description about their life, nor did they reveal their sorrow and grievance to their families. This was not because their unrefined pens could not convey the complicated happenings around them, but because there was a different basic attitute toward letter-writing. For it would be an unwise action to tell one's family the sufferings abroad. In doing so one would only cause them anxiety, which meant either a son of unfilial piety or a husband of inconsederation. Why then tell the truth? Let all the distress rest upon oneself alone!

The sole purpose of writing a letter home was telling that the wayfarer was still alive, so as to relieve the family's worry. This is thoroughly demonstrated by a short letter written by an unknown person to his wife. From the tenderness of the words he used, from the manner in which he tried to console her and from the way he imitated classical Chinese style of writing improperly yet naturally, one can easily sense his bitterness.

Miy. Beloved itife,

It has been several autunns now since your dull husband left you for a far remote alien land. Thanks to my hearty jody I am all right. Therefore stop your embroidering worries about me.

Yesterday I received another of your letters, I could not keep the tears from running down my cheeks when thinking about the miserable and needy circumstances of our home, and tilinking back to the time of our separation.

Because of our destitution I went out, trying to make 
a living. Who could know that the Fate is always opposite to man's design? Because I can get no gold, I am detained in this seciuded corner of a strange land. Furthermore, my beauty, you are implicated in an endless misfortune. I wish this paper would console you a little. This is all what I can do for now. . (See Letter No. 1, Appendix A.)

The letter was unfinished and not mailed. Ferhaps the writer was overwhelmed by his own bitter thought and could not continue his writing. He even did not have money to send to his darling "beauty."

Normally the Chinese wrote letters when they sent money home. In a letter to his parents, a son wrote:

Writing respectfully, beloved parents, kneeling beneath at your feet, your prodigal son begs you do not worry about him. You will know I am well as you read this message. It is I who wish you both health and strength, and every member of the family peace and safety. Enclosed is thirty dollars. Please check the sum. It is at your disposal. I have sent five hundred dollars early in December, last year, but so far I have not heard a single word from you. I am deeply worried as I have been waiting for a reply day after day. So please write me as soon as possible. (See Letter No. 2, Appendix A)

Letters from families in China usually urged the laborers to return home. "I can not sleep and eat well because I am always thinking of you." wrote a mother to her son at John Day. "I hope you will be home and get married," continued this mother,

while I an alive, so that I might die with my eyes closed without grievance. I also hope that you wil.I take care of Ah Fung, your nephew. Help him get a wife and establish their home, so that both your Father and eldest Brother might feel. relieved under the ground.

You should save some money and should come back at least next year. I know my days are numbered. You 
won't see me any more; I may already be gone by the time when you come back. Would you feel sorry then?

The twenty dollars which you sent me last June was received. So I guess you are all right and that relieves me a little. However, so long as you are not home, I am in suspense. Come beck, don't forget your mother, please. (See Letter No. 3, Appendix A.)

Probably this son had never returned home as his mother wished for his mails dated as late as 1942 were still found in the Kam Wah Chung building.

A wandering son should return home as soon, or as often, as possible so as to bring about a family reunion and share his success, either of finance or of professional fame, with his family. "Come back whenever you can get a little fortune, so that our family can be reunited." was a common voice from their families in China. It was not because the parents were selfish but because of something connected with "face". A son who did not like to come back was an unfilial son, and an unfilial son in every respect was a shame to his family. "Come back as soon as you can. Don't say 'no' to me any more," wrote an angry father. "There are too many gossips in our village that make me uneasy." (See Letter No. 4, Appendix A.) of course, there were other reasons to make that father angry. He reprimanded his unforgiven son:

- You have no brothers, and your age is near forty, but still without a malc-offspring. You should think carefully. If you neither make a fortune abroad nor have a son at home, your loss is double. So why not come home before it is too late. (See the same letter.)

If the father's sterrness could not bring back home the untoward son, then letters Irom his mother and wife would fly 
to him as numerous as snow flakes. "According to Mr. Wang you are indulging in sensuality," complained a wife, "and have no desire to return home. On hearing this I am shocked and pained. I have been expecting your return day after day, and year after year. Your mother is completely blind. The housework is oppressing, and I have no one to give me a hand. If you have any conscience, please come back immediately. . ." (See Letter No 6, Appendix A.)

If neither softness nor complaint of the mother or wife worked, then the call from children might reach him:

My. Dear Father:

Prostrating myself at your knees, I write this letter and wish you health and well being.

Father, you have been abroad for so many years that you must have made a big fortune. But $I$, your humble daughter, am always thinking that I have never seen my Father. Last year, we-Grandparents, Mother, and I--have wishfully thought that you could come home, but wie were all disappointed. Oh, Father, we have not heard from you for four years. I, your humble daughter, beg your quick return home. . Father, you are now aged. Needless for your daughter to remind you to come back. (See Letter No. 5, Appendix A.)

If this still was in vain, then might come letters from

all his relatives.

My Competent Nephew:

I have sent you several messages when your mother traveled heavenward two years ago. And I also informed you many times that your father was heaven bound on June 6 , last year. But 1 have not heard from you for years. Have you received what I have written to you? I think you must have received them.

Don't you remember the old saying: $A$ son is raised for the purpose of being companion to his aged parents. You have failed to fullfil this significant duty; now you should come back right away to arrange the affairs left benind by your parents. - Your wife is looking forward to your 
homecoming. - (See Letter No. 7, Appendix A.)

Another letter from a cousin goes like this:

My Older Cousin:

What a long time it has been since you disappeared to a far-away country! Like Su :Tu who herded sheep by the North Sea [in Siberia], no one in the world knew where you were. Everyday I wish to gaze upon your virtuous countenance but cannot; each time a column of wild geese filies across the sky, I think of you. We are derived from one body, like hands and feet, yet have unfortunately fallen apart, one in the east, the other in the west. When will we see each other again?

- - I don't mean to blame you for not sending money back, because I understand that you might not have been lucky as to get enough money, but I really cannot figure out why you do not write home. Neither can I see why you do not like to come back. . . If you do not come back, you will regret forever. (See Letter No.8; Appendix A.)

Under these pressures, an immigrant, even with an idea to settle in this country, would find it difficult to resist the solicitations from home.

The Chinese at John Day also advised each other to go back China. In a letter to his uncle, in America, a nephew wrote from John Day:

- . You must have already acquired plenty of gold and silver for an earlier home return. We fellows at John Day, being your nephews, also share your success rejoicingly.

From your previous letter, I find that you still delay in this country. You told me, however, in your letters, several times that you were packing and purchasing the ticket for home, and I entirely believed it. Why then, have you changed your mind? Anyway, I advise you not to rely too much on gold, but ought rather to return home early. The wisest course is to get married and settle down at home while your parents are still alive. (See Letter No. 13, Appendix A.)

Sometimes, people in China would seek help in terms of coming to the United States. 
My brother and I are almost idle at hone, as if our hands were bound. I tutor sometimes, but I hardly make a living for the present, nor have any hope for the future. Trerefore, I aspire to seek my fortine abroad to support my family. But I am unable to take any action, for I cannot afford the fare for the passage, nor can $I$ find a source from which to borrow. Furthermore, I don't have any brother abroad to render me the needed assistance. There seems no way for me to escape this country. Only you, my cousin, have the ability to help me because of your excellent condition there. I pray that you will extend a hand to eievate me.

I have sent several letters to you, but received not a single word from you. It seems you are too apathetic. Why? Please answer me soon this time. (See Letter No. 19, Appendix A.)

Some letters reveal personal quarrels among the Chinese in this country.

Referring to the entanglements between Ine Pang-chi and Wu Fan-chang, every one of our countrymen here and the Americans, too, all think that Pang-chi is evil and vicious. .

By the invitation initiated from Pang-chi, I tried to arbitrate their quarrels. But all my efforts were in vain when he realized that my manner was fair to both sicies, but not in his own favor only. He defied my setilement and continues his presumptuousness and outrageousmess.....

He agitated among the Ings--his brothers and cousins-to be against me and defamed me with maljcious slander that I was bribed by Fan-chang. But your uncle, I, only have one idea in mind--to serve the two parties righteously and justly. I can stand straight in the presence of ghosts and gods. (See Juetter No. 24, Appendix A.)

No letters related inter-group conflicts at john Day.

Nor was there any indication reflected that the Kam Wah

Chung Company functioned as a loan-shark. Instead, there is

a letter testifying that the company tried to borrow money

from others.

Speaking of our business it is very hard for us to 
keep the store open. The New Year is approaching, but we still don't have the merchandise for sale. My partner lung on, while he was on his way to procure some goods, lost all our money because of gámbling in Portland and Baker. That is why our store still lacks of groceries. But please don't let others know, lest they would laugh at us or not believe it. If you have spare money, please lend us forty or fifty dollars for procuring some commodities from Portland. I will repay this loan to you at the time you go back China. (See Letter No. 12, Appendix A.)

Although the letters cited above carry no spectacular events but only the trivial things which happened in their dull, gloomy coolie life, still it brings us the insight to understand their story. The principal theme of the letiers from their families was either asking them to "return home" or asking them to "send money back". And the main subject of their letters to home was: "I have survived", or "Here is a little money for you." 
FOONTNOTES FOR CHAPTER V

${ }^{1}$ Interview with Gordon Glass, the president of the Kam Wah Chung Museum Committee, June 14, John Day, Cregon.

2 The Blue Mountain Eagle, February 3, 1902.

3 Pearl Becker, "Early Chinese in the Northwest," st.

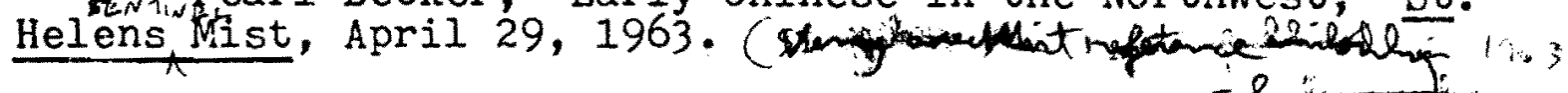

${ }^{4}$ John P. Esvelt, "Upper Columbia Chinese Placering," The Pacific Northwesterner, Vol. 3 (winter, 1959), pp. 6-11.

${ }^{5}$ Grant County News, December 15,1883 , Oliver Historical Museum, John Day, Oregon.

6 From the records left in the Kam Wah Chung Co. building.

7Leon B. Baketel, Oregonian, June 6, 1936, p. 21.

${ }^{8}$ Interview with Bob wing.

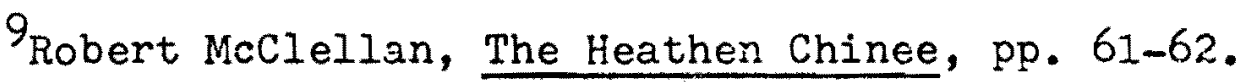

10 John B. Horner, Oregon (Corvallis, Oregon: the GazetteTimes, 1919), p. 245 .

11 The commercial correspondence and invoices left in the building of the Kam Wah Chung Co.

12 Thomas A. Bailey, A Diplomatic History of the American People (6th ed.; New York: Meredith Corporation, 1969), pp. 520-5?4.

${ }^{13}$ The Japanese in the U. S. were 2,039 in $1890,24,326$ in $1900,72,157$ in 1910, and 111,010 in 1920.

14 The Blue Mountain Eagle, February 8, 1901.

${ }^{15}$ Ibid. , February 1., 1907.

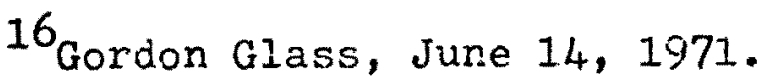




\section{The Oregonian, January 23,1967 .}

${ }^{18}$ Manchuria was an American steam ship, 13,038 ton, built in 1904, signal letters were K.S.W.C. Siberia, 11, 284 ton, built in 1902, signal letters, K.R.W.G. Both the ships belonged to the Pacific Mail S.S. Co., see Department of Commerce bureau of Navigation, List of Merchant Vessels of the United States, 1913 (Washington Government Printing of'ice), pp. 235, 294 .

${ }^{19}$ The label on the records says: Carl Lindstrom A. G. Berlin. 


\section{CHAPTER VI}

\section{RELIGIOUS LIFE AND NEN YEAR IN THE CHINESE COMMUNITY}

Wherever a Chinese community existed a Chinese temple would be erected. As the church is to the christian, so is the temple to the Buddhist. The temple that was once in John Day's Chinatown is gone. Today only a small shrine is left in the building of the Kam Wah chung Co. It can be properly called a altar. Following tradition, the throne of the idol is on the top of the middle shelf against the back wall. In front of it is a large table full of religious articles. They include: a round box made of bamboo with 91 bamboo tallies it it, an incense burner, joss sticks, fire crackers and a bear claw in a wooden box.

The shrine is decorated with ribbons, colored strips of paper. around it are also lamps, mysterious red and yellow papers, dried fruits, and candles, But strangely, no idol sits on the throne as it is supposed to. The holy title of the "absent" idol is found somethere near the shrine, which reads "the General who subdued barbarians," and "Chen" was his last name. People liked to call him "Old General Chen," when they referred to him in their letters.

Religion is sometimes linked with commerce. A shrine or altar within the company could be regarded as a branch of its enterprise. When the shrine needed to be remodeled and tine statue redecorated, the worshipers would contribute. 
When the believers came to pay homage, they would have to buy the incense and other supplies essential to their worship from the store. Again when they wished to be blessed and when a good omen came true, they would offer their donation in gratitude. There are many small red papers posted on the wall around the shrine, each of them telling the amount of money donated by specific individuals as an offering to the deity. These papers show that the shrine installed in a store must have been a commercial means to collect money for the company. Yet in the light of the hardship and lack of safety these heathens faced, one can understand that their need for religion was tremendous. A shrine in a store then was but a natural thing. Being the people of a contemptible race, and living in the lawless mining communities, their lives were at anybody's mercy. The massacre of the Snake River in 1887--thirty-three Chinese killed and $\$ 6,000$ in gold dust robbed by only five white men--was only one of countless incidents of that kind. I In addition, the different climate, bad food, exhausting manual labor, and many other hazardous tasks involved in their employment had already taken a great number of the lives of their fellow countrymen. ${ }^{2}$ It seemed that if they could return to China all in one piece, it must be by the mercy of the dieties which they had worshiped since their childhood. And besides, the wish for gold from the earth alone would keep them prostrate at the feet of their déities. 
"Old General Chen," because he was considered very protective, responsive and mighty, was, therefore, a very popular deity in the province of kwangtung. 3 It would be most fortunate to have such a deity come to John Day. It is interesting to notice his title "the General who subdued the barbarians," in the context of America. White people seemed to be "barbarians" in every sense of the word. Their fierce looking face, hairy arms, strong body odor, terrible food habits-craving for eating beef, half cooked and half bleeding-loose family ties, lax sexual behaviors, and, above all, their primitive way of settling disputes by gun, all characterized them as an uncivilized people. Yet these white "barbarians" were hard to cope with, for they were unusual "barbarians" possessing the highest scientific sophistication in the world. There seemed no effective way, except by supernatural power, to deal with them. So the last resort available to the Chinese was their heathen idols. "Old Gereral Chen," with his reputation of subduing barbarians must have been an ideal deity to protect them in this barbarous land.

But "old General Chen" did not come to John Day "in person". Three times the men of the company prayed to him to come and three times He refused. Therefore, they could not make a duplicate idol of Him, to carry to John Day, but only a small tablet for Him in the shrine. Whether He did not like to be transferred to another country, or whether He himself knew that He could not subdue the "white 
barbarians", is still unknown.

The devotion of these heathen chinese to their religion was reflected by the corparatively "magnificent" temple in Baker City's Chinatown. The temple was built in 1882, when the Chinese numbered only 400, at a cost of $\$ 10,000$. It was a red brick, twenty by forty-five feet, two-story affair with balcony and porch in front. Located on the bank of the Powder River, was the most impressive building in Chinatwon. 4

With such a well-built temple available, a deity would be very glad to live there. So an idol was imported, by His own consent, from China to the town of Baker, and was described vividly as:

In the Ornate Joss House sat a man-sized Buddha in the silence of burning incense and candles, highly decorated and deeply reverenced by the Chinese.5

The Chinese must have been very satisfied to have one of their revered gods live with them and protect them. He must have also been a very powerful one, at least equal to that of "Generai: Chen" at. John: Day". But he proved to be a useless or even a disastrous to his believers for one day he was kidnapped by some white boys.

There was much consternation and mourning by the priestiy temple attendants. A iiberal reward was offered for the return of "Georgie", as he was called by tine boys, and soon "Georgie" came back unharmed.6

Even though "Georgie" was unable to protect himself, and "General Chen" was too "old" to come John Day personally, the 
Chinese still had faith in their jdols, or tablets. There must have also been small red papers posted around "Georgie", and money donated from the believers for the use of oil and incense, just like for that "old General Chen" in the Kam Wah Chung Company.

This typical red paper found in the building, dated February, 1905, illustrates well the attitude of the Chinese toward their deities:

With three dollars donated herewith, I ask you to divine four inquires from old General Chen:

First, about myself [my future, health, safety, etc.]

Second, about my fortune.

Third, about my employment on the farm of a barbarian.

Fourth, about my return to int. Vernon [?]

Please do this for me as soon as you receive this message. I don't mind on which day you divine; both the second or the fourth of month will be all right for me only if you can do it quickly. Send me the answers at once. I have divined about my business from 0l.d General Chen more than ten times. The answers turned out close to reality. I believe Him deeply, and rely completely upon his guidance to direct my business. .

I also wish you two gentlemen great prosperity to insure your return home..

Without a temple or a shrine in the community, a Chinatown seemed incomplete. After retiring from a day of back-breaking work the Chinese community in John Day's Chinatown, appeared much like their own hometown. The same color of skin, the familiar facial expressions and the same "slanted" eyes, all made them feel as if they were in China. With their ears hearing the dialect which was once the only language in their world, their eyes touching the colorful shrine, and their noses meeting the lovely and sacred smells 
of the burning incense, they seemed completely back at their villages. If they indulged themselves for a while smoking opium on the bunk and sharing news about their fellow villagers, they might totaily forget that they were still in an alien land.

The "heathen Chinese" took their religious affairs quite seriously. Many notes were dispatched from the company to ask the believers to donate. One of these noted found in the building is partly recorded here:

clothing is to be changed. Every member here had
donated' heartily and excitedly. All of the projects
are to be finished by the New Year. If you, my Uncle,
are among those who have not yet given a donation,
then please, by all means send it soon. If you do
not hurry, you will lose the opportunity for offering.
(See letter No. '?, Appendix A.)

The note was written by Hay to his uncle, and should not be considered as commercially motivated. A man would not usually cheat his close relatives. And Hay was not a person to gain money without principle, as we will note later.

The note also reveals that religions activities were scheduled around the New Year. Appearently, the reason was that all the chinese would get back from their work camps to Chinatown for the New Year. Therefore, it was the most suitable time for religions events. The New Year was indispensable to the sojourner's life in the United States, not only because it was the most important traditional festival, but also because it was a special occasion full of joyful 
memories going back to his childhood. With its colorful activities, every one looked forward to it earnestly.

The festival of the Now Year usually lasted for several days. The white, out of curiosity, also observed it. The Blue Mountain Eagle reminded the inhabitants: "Next Monday is the big day of China new year. The small boys will all visit the Chinese headquarters in the city on this day."7 In another issue, it reported: "The Chinamen are gathering, in from the sheep camps to celebrate China new year." 8 When the new year was over, the newspaper reported: "China new year ended Tuesday, and the day, being bright, a large crowd of ladies, men and boys witnessed the grand display of noise."9 Another new year's report goes like this: "Last Saturday the Chinese residents of John Day closed their New Year celebration by Eiving their Joss a 'big feed' and exploding about $\$ 200$ of fire crackers:10 A more detailed account about the Chinese New Year was found in the Grant County News,

Chinese New Year

Last Friday the Chinamen commenced the celebration of a feast commonly known as the Chinese New Year. A News reporter visited their habitations last Sunday afternoon, and found the Celestials in the midst of their festivities. On every hand were to $b \in$ found dishes of rice, plates of nameitandtakeit and burning tapers, while the moon-eyed denizens of the town were stretched on beds and bunks, indulging in tobacco, opium, whiskey and other narcotics. At this season the usual parsimonious Chinaman is always liberal to a certain degree, and our reporter was proffered several cigars, privilege of a pull at their opium pipes. The devotees of the pipe were all busily engaged in their favorite pastime, and several of them seemed to be under the influence of the drug. Il

It would be more accurate to say that the several 
Chinamen seemed to be "under the influence" of "homesickness". Sentimentality is one of the Chinese people's weaknesses. The reminiscince of one's home usually made and still makes, a "Chinamen" very homesick on some special festival days, new year days in particular. Consequently they sought the assistance of liquor and drugs to alleviate their sorrow. Another factor which induced the "moon-eyed" Chinamen to celebrate the new year elaborately stemmed from racial dignity. Knowing that their frugal and hard-working habits-the traditional Chinese virtues--were unpalatable to, and scorned by, the whites, they had an eager desire to show the whites that they were also human beings--craving rest and recreation, as well as having a tendency to spend money unparsimoniously. Therefore, they would invite the whites to share their happiness in the new year. That was why "our reporter was proffered several cigars," and was even proffered "the privilege of a pull at their opium pipes." But the result of the Celestials' hospitality usually proved to be disheartening. The reporter continued his Chinese New Year adventure as follows:

To prove what a curse the Chinaman is in introducing the life and soul destroying habit of opium smoking, we have only to cite one instance that came under our notice.

We were accompanied by a nine-year-old boy to whom the pipe was freely offered, and, indeed, he was frequently importuned to partake of its intoxication. If they are so liberal in bestowing their favors upon boys would they not be so with youths of a more susceptible and inquisitive age, and thus sow the seeds of a life of dissipation and disgrace?" 
Here was the confrontation of the two different races. On the one hand were the stupid, uneducated and debased Chinese miners who, at the moments of their high spirit, offered their guests the privilege of a pull at the thing they held preciously. Obviously they thought that, by doing so, their hospitality and generosity, as well as their humorous sense (by bostowing their favors upon a boy) would have been appreciated. On the other hand, there is a critical and a suspicious reporter who interpreted everything in its worst meaning. Anyhow, the Chinese should be accused for their foolish behaviors as to make fun of the white boys. And fortunately for the white boys, that the Chinese laborers were too poor to afford frequently this expensive way of "sowing the seeds of a life of dissipation and disgrace." 
$I_{\text {R. McClellan, The Heather Chinee, p. } 63 .}$

2 Here is an example: "Three Chinamen were recently killed by an engine at Bonneville, and the railroad company has settled with the executor of their estates by the payment of $\$ 1,000$, which establishes $\$ 333.331 / 3$ as the price of a dead Mongol." The Grant County News, February 19, 1885.

${ }^{3}$ Interview eith Bob Wing--Doc Hay's nephew.

"Wesley Andrews, "Baker City in the Eighties," Oregon Historical Quarterly, Vol. 50 (1949), pp. 87-89.

${ }^{5}$ Ibid.

6 Ibid.

7 The Blue Mountain Eagle, February 15, 1901.

${ }^{8}$ Ibid., February 23, 1901.

${ }^{9}$ Ibid., March 8, 1901.

${ }^{10}$ Ibid., February 18, 1902.

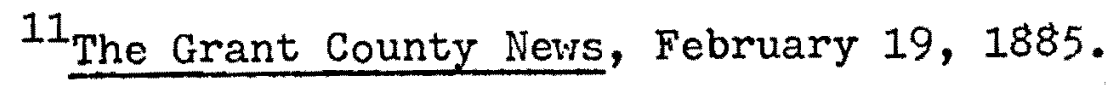




\section{CHAPTER VII}

\section{THE DECLINE OF THE CHINESE COMMUNITY AT JOHN DAY}

The Chinese community at John Day declined around 1910. Many moved out, or back to China. Few of the new immigrants from China, or from other parts of the United States, came in. Since the situation generally improved along the West Coast around the turn of the century, few of the immigrants would prefer to come to a small town like John Day. The decline was reflected in the invoices of the Kam Wah Chung Company, which were gradually decreasing in number after 1906. As a matter of fact, the Chinese communities in this country had declined in general, since the Geary Bill of 1892 effectively checked the influx of chinese inmigration.

Still, there was something not ordinary in the account of the retrogression of some Chinese communities. The Chinese at John Day were still an isolated group among the whites. Their relations with the whites did not progress too much. Feople in this area, though much friendlier than those in many other towns in the state, were not without discrimination. The "fire incident" and the exclusion of the orientals from Canyon City revealed this. The following quotation taken from the Blue Mountain Eagle of January 3, 1902 is another indication of the relations between the white and the yellow:

\section{Take Warning}

Those persons who have heretofore conducted themselves jn an unlavful manner about Chinatown in John 
Day, during China new year, or at other times, are hereby warned that we will not tolerate such in the future, but will prosecute such persons to the extent of the law.

Kan wah chung \& Co. See Ling Co. Quong Yuen Lung [Co. $]^{1}$

Chinatown was sometimes invaded by some hostile people. Cowboys, for instance, often did. When they came to town and got drunk, they rode into the Chinatown, cut off some "Chinamen's" queues, and ran away. Twice the Chinese considered leaving, but found there was nowhere better than John Day. 2

A more serious incident happened on April 17, 1905, when Chinatown was "searched" and "ransacked" by a number of

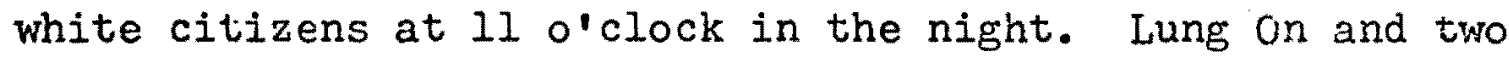
other Chinamen were carried away and thrown into jail for having opium in their possession. And the rest of the Chinese were ordered to get out of town by the first of May. ${ }^{3}$ In his letter to the Chinese Consul at Washington, D.C., A.W. Leedy-Long on's attorney-remarked:

I believe that the rights of the citizens of your country have been invaded in this matter, but do not think that justice could be obtained in the local courts, and believe it to be for their best interests that the case should be taken up by your Goverment in our Federal Court. The testimony is conclusive that these people [the whites] acted without any warrant or process of law. (See Appendix C for the letter.)

This incident took place at the time when the Kam Wah Chung Company's business was at its peak. It seems that some whites resentod a Chinese comminity booming in their midst. 
Also stimulating their plan for ridding john Day of its Chinese, perhaps, was the fiery rlash of the Tong war breaking out at that time in Portland. 4

The Chinese did not get out of John Day as they were ordered. Lung on and the two others were each fined $\$ 100$. (See page 179 for the receipt of the fine.) This; perhaps, was partly because the demand of their departure was unlawful and partly because it was demanded by only a few persons, indicating that most white citizens tolerated their oriental guests--a tame and peaceful people.

Throughout history, the Chinese immigrants in this country seldom, if ever resisted the attacks, riots, and violence of the whites. They, themselves, also felt guilt and admitted that the accusations against them were somewhat true--that they were the "beggers" in the United States, and snatched away a bit of bread from the mouth of the white. They seemed to understand that it would be useless for them to stand up and retaliate against the white, not only because they were too weak to achieve success but also because the whites were their potential employers. Too, the fear of being deported also forced them to subnit to the whites. They fully realized that the power to protect themselves, except that of their deities, would not come from their own, nor by building a thick wall of stone like that of the Kam Wah Chung Conpany, but by building something more reliable-the wall of friendship. 
There were many proverbs in their ageless tradition which might be helpful in the adverse circumstances in which they found themselves. Among them. vere: "Recompense injury with kindness," (从徳敦然); "Lack of forbearance in small matters upsets great plans,"(小不忍则乳大謀); "The soft overcomes the hard," (委以克㔉); "Even the metal and stone can be melted by the warmth of sincere friendliness," (誠之

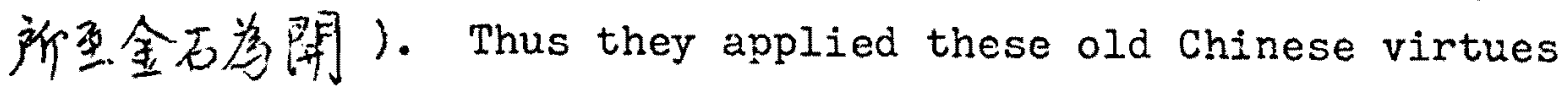
to the new American environment. To a certain degree, they succeeded. Who could forget such a Chinese servant as Wat Sen, who tried hard to please every member in his master's house?

Wat Sen, the old Chinese cook who had been in my ... aunt's family past any of our memories, was a great favorite among the younger members of the family. He spent his life catering to uncle's rather luxurious tastes and succeoded remarkably well. . - - Dear Wat Sen, we children loved him and no wonder, for our many visits to the kitchen never bothered him. There was always a bit of chocolate, a cookie or a few raisins for each of us. At hcliday times he was very generous to us all as the Chinese traditionally are to the ones they serve. . .

Other gifts that have been carefully treasured long years, came to us on that happy evening [Christmas]-three of them from good Wat Sen. For myself, a fascinating little lacquer chest of drawers about ten inches high, a marvel of oriental handivork with carved metal pulls. . .5

And then there was Sing Koon who cleaned strenuously the streets of Canyon City-a work which in any case no other person would care for.

FriendJy with everybody was jolly Sing Koon. Twice a week in the sumnertime he used a broom and shovel on the business streets. Back and forth he went to Canyon Creek with a wheelbarrow to dump the collections. 
Each business house paid him 50 cents at the day's end. ... Upon the approach of a freight caraven of corved wagons and trialers drawn by six or 10 horses, sometimes composed of three or four outfits--their arrival announced by the jingling bells which decked the collars of the lead horses of each team--old Sing was warned that he was in for a big day of work on the morrow, and no extra pay. The teamsters parked their caravans in front of every store and then unloaded onto sidewalks, while the horses champed their bits and stood on the narrow streets, blocking all other traffic. And the next day! Sing Koon wheeled load after load to the banks of Canyon Creek--enough to fertilize many gardens. 6 But he loved the horses and he never complained.

A letter written from a cook to his hostess, which is found in the Kam Wah Chung Company, is another illustration of the Chinese employees' attitudes toward their bosses. $\therefore$. I am quite well. . . and have a good time with friends on Chinese new year. . and having but $\$ 300$ worth fire crackers to shooting [sic] and on [the] same days our Chinese having [sic] big festival for the new year least [sic]. So I am very sorry your fords [sic] cannot visiting [sic] with us here. So I just try to send you a little presents with a pet flower Baskets, one silk apron and a picture with my friend lung on on [the] hope [that] you will goting [sic] soon and Please reply. I remean [sic]

(See the whole letter on page 183.)

Respectfully yours, Servant Cook

Ah Ork.

These citations are only a few examples of the manner in which the Chinese tried to win over the. white community by their devoted service, consideration, and warm personality. Despite all their endeavors, they could not overcome the general trend in this country, which was not favorable to them. First, the utilization of machinery in the mining industry in this district left no room for the extensive 
employment of the Chinese laborer. The mining of gold and other metals was still a very active enterprise after 1900, but most of the mining work could be done by machinery. The Blue Mountair Eagle mentioned some of the principal mines which had applied modern equipment to their operations. has opened up 10,00 , feet of tunnel. . The Red Boy
is equiped with of the most complete and modern mills
in the state and represents the expenditure of nearly
a quarter of million dollars. . .

Secondly, labor organizations were introduced into this area during this time. Without the permission of the labor union, a mine owner had difficulty hiring workers, including the Chinese. The following quotation from the Blue Mountain Eagle reveals this situation:

The readers of the Eagle will remember that it was only a few weeks ago that a miners' unior was organization at Sumpter and neighboring towns. This organization is bearing fruit at this early date. Just last week twenty-fj.ve miners walked out of the Golconda mine and refused to work. The next step they will refuse to allow any other person to work in their stead, . . The labor organization is all right. . . but he should not attempt to prevent the employment of other men.8

Undoubtedly the "Chinamen's" employment in the mining field was greatly restricted by the establishment of the labor union. This was a general phenomenon if the whole state of Oregon, not merely something happening in Grant County. An article in the orezonian would later point this out quite explicitly:

Half a century ago Portland was still an outpost of hard pioneers, and a great deal in the way of physical toil needed to be done to establish a civilization. 
The Chinese worked side by side with those pioneers, and contributed much in the way of clearing land. . . The extension of the silvery threads to the east was a tribute to Chinese labor, but it also sealed their fate, for it bought the great flux of eastern laborers who soon established unions and drove the chinese from all lines of endeavors. The factories, the public works and the most business are closed to them. 9

Thirdly, Oregon law made it difficult for the Chinese to survive. Although Chinese in Oregon enjoyed comperatively better treatment during the periods of anti-Chinese agitation than Chinese elsewhere, nevertheless conditions in Oregon were still difficult. "A law enacted by the Oregon legislature did not gave the Chinese in the state even a 'Chinaman's' charice," commented a writer of the oregon Statesman. The legislation in question which levied up to $\$ 50$ per month tax against an individual Chinese was titled: "An act to tax and protect Chinamen mining in oregon." and in fact, the law taxed Chinese whether they were engaged in mining or not, and if the orientals so chose to engage in business for themselves they were taxed $\$ 50$ per month. 10

Powerless in these unfavorable circumstances, the Chinese were forced to accepted any offered job. But they worked at it cheerfully. 11 Such employment as was available to them in the John Day area were those jobs that the whites did not want for themselves: cooks, laundrymen, gardeners, and shepherds. "At the time of my arrival in John Day--1900--the Chinese people were a thriving section." remembered Mrs. Wells, a pioneer woman. 
But the bad times came, when they were no longer able to recover any gold from the residue left by the original white miners. They became sheep herders, cooks, gardeners, laundrymen, etc., and were very

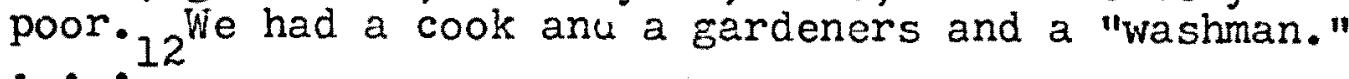

Sheep herding was one of the main jobs open to the Chinese. This is also suggested by the news of the Blue Mountain Eagle--"The Chinamen are gathering in from the sheep camps to celebrate China new year. 13 It was perhaps a job as hard as that of mining, but even more lonely. A herder might not see any other soul for months when he took the flock into the hills. His day was twenty-four hours. He must move out by daylight; must be quiet and rest late so the flock would feed contentedly; must have a map in his mind with special attention to water; must know what to do in case of unseasonal snow on dangerous water spouts; and must look out day and night for coyotes, bobcats, and, in the mountains, bear. 14

The vast Grant County ranges were overrun by more than 200,000 sheep each year at the beginning of this century. 15 Pendleton, a large town in Northeast oregon, and not far from Grant County, was famous for its woolen products. However, the sheep's golden days of supremacy were limited, and gave way to other livestock such as cattle and pigs. By 1908, mules and swine accounted for the largest livestock products in Grant County.16 And the Chinese shepherds were gradually displaced.

As the opportunity for employment lessened, and the 
laborers grew older, many moved to the cities on the coast, and then some to their Chinese birth places. The gold dream turned out to be a nightmare. There were a few lucky ones who returned to China with some "gold" after a venture here of only three or four years. Most of the Chinamen accumulated only pitiful bit of money after forty or fifty years' hard work and thrift. Some even failed to acquire enough for the return fare to China. The most grievous cases were those who died penniless and left their corpses to be carried back to China, or buried temporarily in this land.

In 1906, the government of the Ching dynasty, perhaps moved by the fear of being overthrown by the revolutionists, and in an attempt to recapture popularity from the people, took up the responsibility of transporting all the chinese laborers back to the home land without any charge, providing they were "old and disabled, crippled or suffering from some disease." The Oregonian watched this event interestingly, and presented its readers with a very detailed report:

Orientals Going Home to Die Aged Chinese will cepart to be buried beside bones of their ancestors. At Government expense. . Thousarids of Chinese from all parts of the U.S. have left the country. . The last shipment will leave Tacoma this week. Nearly 400 left San Francisco on the ill-fated Marchuria, which went on the reef on the island of Oahu, Hawaii. Since the San Francisco earthquake and fire, nearly 2,000 Chinese have left the ruined city for their native land. .

In nearly every case the Chinese returning is old, decrepit and indigent. In fact, he is going to his home for the sole purpose of dying. The Chinese have a horror of passing away in this country, and the last effort of nearly every individual" is to get back among 
his own people.

Frequently one dies here and is given the usual burial. Every two or three years the bones of the dead are exhumed, scraped and prepared and shipped to the relatives in China. .

All of the larger oriental vessels sailing from Seattle and San Francisco carry hundreds of old and disabled Chinese. On every trip one or more of the old men pass away. The sight is a pitiable one. Many of them are barely able to move about, live in the steerage and cling to life with the only desire to reach their native shores before death overtakes them. But some of them do not start soon enough and die en route. .

One of the old men leaving Portland tomorrow forever has been a resident here for half a century. . . Many of the other departing Orientals have lived here from 30 to 45 years. 17

No doubt, among these departing Chinese were some who came from John Day, and other towns in Eastern Oregon. Still thousands remained in this state, because they did not qualify for the free shipment. And then, there were also those who did not want to return home with two empty hands, since that was a matter of "losing face." Thus real tragedy faced them. They were caught in a dilemma--unable to make a living in the Gold Mountains, yet unwilling to go back to Tong Mountains. 18 Eventually, some of them even went insane. 19

Among the possible causes for insanity were: their deep concern for their families, the burning desire to strike gold, the culture-shock, and the persecution by the whites. Again, their misfortune would be more bitter by the sight of the prosperity of the white society, the high paying jobs, and the easy life. Deeply disturbing to the Chinese eye was also this beautiful, vast wilderness--running through it were the long, clear streans, rolling across it were the forest-clad 
mountains, the hay was high, and the meadows always green. They saw this beautiful land daily while they roamed with the sheep alone the hills, or welked to their old placer sites. Everyday they caught sight of it--a land flowing with milk and honey-and everyday it remained there, wasted and untilled. They, the land-hungry peasants were prohibited from owning it, only because they were considered as the degraded Chinese. Among those who lingered at John Day were Lung on and Ing Hay, the two proprietors of the Kam Wah Chung Company. Lung on was the main businessman of Kam Wah Chung Company, who was "Born in San Francisco," and "went to Canyon City, the year before Harrison was elected." according to the report of the oregonian. 20 He had been a successful dealer in various businesses:

He owns a great: deal of property along the main street in John Day which he rents and some in other localities. So he has a real estate office. Then he

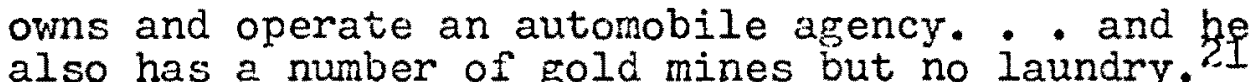

But Kam Wah Chung Company was his principal enterprise; he spent most of his time in the store and died in this building.

Lung on was a brilliant man. $h l l$ of the business letters of the company both in Chinese and English were his work. He was the only Chinese in this area who had ventured into the whitemen's business enterprises. He also seemed very friendly and enthusiastic in helping others. He received many letters asking for his assistance. Very often he buried the Chinese who died penniless. 
Like most of his contemporaries, Lung on was married, and left a daughter in China. But unlike most Chinese laborers, his family was not poor. His parents did not crpect him to send money back, but were longing for his return so that the family could reunite. His father repeatedly wrote him, as did his cousin, that if he returned he could choose the job and position he was interested in, from his uncle's big enterprises both in Kwangtung and Hong Kong. His daughter, by the letter she wrote, (See Letter No. 5) seemed to have been in school for several years; that was an unusual occurrence at that time when education was a male's privilege, and shared only by girls from rich families.

But to their sorrow, lung on never returned; he only sent money occasionally. Why then he did not want to go back home, overlooking his family's hurt feelings? One of the reasonable interpretations might be that he rebelled against his country's tradition. Residing here for such a long time, he must have become more or less "Americanized." Thus he preferred enjoying his personal freedom here to going back and becoming trapped by the family's entanglement in his native land. In other words, Lung on was on of the rare Chinese, who would like to be individually independent at the expense of the family's union.

In April, 1940, Lung on died at the age of 68.22 After his death, the property of the Kam Wah Chung Company was divided; Lurg On's estate and Doc Hay's share were each $\$ 45,000$. 
The money in his name is still in Oregon state today, 23 as none of his farily has come to claim it.

of alj. the Chinese in the Johr. Day area, Doc Hay was probably the most interesting figure. His accomplishments in pulse diagnosis vere so amazing that it is said to be equaled only by the late Dr. Jin Yok Gong, another brilliant Chinese herbist of San Francisco, and gained for him the title of "Doc". There are many stories about him; he is well on the way to becoming a legend in the John Day area. It was recorded that he was so expert in the pulse diagnosis that he could often determine a seemingly baffling case with startling revealtion by merely checking the pulse. Throughout his 59 years of practice, it has estimated that he had saved no less than 6,000 lives which otherwise would have gone to the grave had they nct come to him. 24

once, it is related, a World War I veteran came to Doc Hay for treatment of a "stiff neck," which the ex-soldier thought was neuritis. After a short check, Doc Hay told him he had some shell splinters embedded in his neck that must removed by surgery. This was later substantiated by $\mathrm{X}$-ray at the hospital. 25

Another story goes like this: The herb coctor once told a woman she had five children. "No," replied the woman, "four." Shaking his head, the joctor raised five bony fingers and said confidently: "Five" "Oh yes," exclaimed the woman, "but one didn't Ijve."26 
Doc Hay sometimes did abortions when requested by women. According to an eye-witness, he did it in an incredible manner. He only used sandpaper, a coin, and an onion to rubbsd around the navel. Then he gave the woman some herbs. "Cook the medicine at your home and drink it." said the doctor. "A.II will be over by five o'clock tomorrow afternoon." And it worked, 27 according to that eye-witness.

Mrs. Jone W. Murray, a postmaster of Dayville, Oregon, in her correspondence to the author, disclosed:

My late father, Floyd Lee officer, was a rancher in the Dayville area for years. Our family was well acquainted with Doc Hay, a partner in the Kam Wah Chung Co. at John Day, Oregon. He and my father were great friends and enjoyed visiting with each other. Doc Hay always gave us children chinese candy, oranges and other goodies.

I was a polio victim when I was 12 years of age, and I know if it had not been for Doc Hay's herbs and liniments that I would not be alive today to tell this story. At one time it was difficult for Doc Hay to get the herbs he needed. When I had polio was one such time. He finally told my father that he was afraid he could not pull me through my illness. When my father told me that Doc Hay thought we should go to other doctors, I told him, "If Doc Hay don't do it, no one else can do so wè might as well go home". When Doc Hay heard what I had said, my father said tears came to his eyes, and he said he'd keep trying. The result? I'm still alive and going strong.

He also treated my father for stomach ulcers, kidney ailments, and rheunatism through the years, as well as saving the lives of my father and one of my sisters when they had pneumonia. We usually brought the herbs home and cooked them according to Doc Hay's directions, but sonetimes he prepared it fo: us. .

He also very successfuliy treated blood poison, and even rattlesnake bites. I had been stung by a wasp one time, and by the next day there were signs of bloodpoison, but after getting medicine from Doc Hay, it was soon overcome. I wish I could get the same medicine to keep on hand for treating bee stings--it was a gray powder that I was told to mix with vinegar, 
and to paint the area around the sting.

We used a red powder that we called "sneezy powder" which Doc Hay gave us to use when suffering with severe head colds. It was blown or drawn into the nasal passages through a straw. I used it many times, and it seemed that I would sneeze my head off, so to speak, but it always gave me relief by causing the nasal passages to drain. I haye never found any other treatment as effective.28

Hay came to the United States in the company of his father. They may have stayed at Walla Valla, Washington, for several years and then separated: the father went back to China and the son to John Day. Many of his uncles and nephews are still in Walla Walla (see Letter No.23, Appendix A). At John Day he met Lung on, thus began their partnerships as well as friendships for more than fifty years.

Hay must have had, to a certain degree, Chinese medical trajning, but it is unlikely, that he was from an outstanding traditional medical family, for his family was poor. His father did not make much money while he was in the United States. As Hay did not send money back for many years, his father, disillusioned and angry, stormed at him with numerous long complaining letters.

Doc Hay started his medical life in Kam Wah Chung right after he took part of the business. He got many Chinese medical books which are still in the building today, and studied strenuolisly. In a few yearc, he acquired a tremendois knowledge, as well as experience. His reputation grew rapidly. The Chinese laborcrs around John Day were his best and most faithful patients. Gradually the white patients also came to him, as there were not many good doctors and medical 
facilities available in that area. Indeed he was a very good doctor and was known all over eastern and central oregon. Letters and prescriptions left in the building show that his patients were all over Oregon and Washington, most of them were white people. Here is a letter which Doc Hay answered a patient from Portland.

Dear Mrs. J. Schwerdt: $1 / 2736$

We received your letter and we would not advise you to come over here to stay as it would be so expensive. We do not know anything about the doctor in Portland, if you have more faith in us, we will be glad to send you a couple of packages of medicine to try.

Two Chinese, encouraged by his success, opened a herbal office in another city, but soon failed. Here is part of the letter from the unlucky herbalist to Hay:

I started a herbal shop with $\mathrm{Mr}$. Fon-yao in Astoria late March. But we did not know that the people here were not interested in the use of Chinese herbs. The business was so bad that we were forced to close. . (See Letter No, 20.)

The herbs for his medical practice were purchased from San Francisco and Portland. The invoices for the herbs give us a clue about his medical business. By 1910 his medical business was good and already as important as the: other trade in the store, because the invoices of general goods do notroverwhelmes those of herbs. But after 1910, when general goods declined, the herbs were still in great demand at the store.

The herbs used in treatment were various, from plants to animals, and from minerals to organics. Some strange or even terrible medicine in Westerner's eye were: poison snakes 
in alcohol, dry lizards, shells of cicada, and opium.

Iike Lung on and most others, Doc Hay was married before he came America, and left a son and a daughter at home. It was his duty to support them, but Hay almost neglected it. This made his father furious. In a letter to Hay, he wrote:

Time slips fast. I have been home for several year since I left you. I recall at the time when I was buying the ticket for returning home I determined to buy one for you, too. But you did not agree on that. You asserted "Let the old return home; let the young stay abroad to make money." you were 100 percent right!

I don't blame you that you did not send money back in the first years because I consider that you might have encountered hardship at the beginning. But now things are quite different. You have fortune at hand. Normally, you should have come home to see your mother and wife, even only for a visit. Then, a few years later you could return to the United States again. But who could believe that you had never sent back anything, neither a penny nor a word. I have written you many times to ask you send a little back twice a year. So far the only thing I have got from you is "disappoint.ment."

Don't you know that to mail a letter to you I have to spend nearly half dollar. Now we are in such bad condition, where can I find half dollar for the postage? You, in America, have liquor to drink, and meat to eat, so you no longer remember that we are still starving and cold.

A Chinese father was absolutely right for his anger at his son who "in America, have liquor to drink, and meat to eat," so he no longer remember that his family were "still starving and cold." Of course, they already knew that Hay had been very successful in his business, and became unbearable at Hay's ignorance of his obligation. His cousin wrote to him:

Yesterday a compatriot came back from the same place you stay. I asked him about you. I was extrenely pleased then he told me that you "were in an extraordinarily vell-off contition. At the sametime $I$ am 
puzzled why you have sent home neither gold nor letters. (See Letter No.18.)

Another cousin wrote to him as follows:

I have heard recently that you possess the mighty power of turning the heaven and upsetting the earth with your medical technique, and are looked up to as the greatest among all physicians. No doubt, then, you must have made a great fortune, for profit always goes with fame. How your family will be enriched by your accomplishment when you come back. But their situation now is thoroughly wretched. . (Letter No. 19.)

His family was in such a desperate condition that they were even forced to consider begging:

At the present, prices go up. The cost of rice is as high as that of pearls, andfirewood as dear as cassia. Your home is in a desperate condition beyond describing. The moaning of your family from the cold and their crying from hunger can be heard frequently.

This spring I have lent them some money when I found that they were going to stretch hands to beg from door to door. I note that since our great great-grandfather, no one in our fanily had been seen in such bareface shame as to beg.

That small amount of money borrowed from me must have been used up. If you do not send sorne back, they will probably have to embark upon the road of begging. I am unable to help them any more although I intended to, for I myself am not in a good situation, either. (See Letter No. 18.)

Hay planned once to let his son come to John Day. This

is known from his son's letter to him:

Yesterday Uncle Yu-po arrived home. He gave me your message that I might go to the Gold Mountains if I cculd first study for two years. If this is your will, your son, I, is greatly delighted. But considering the privation of our home, plus the fact that $I$ am still in debt to others three hundred dollars which I borrowed a couple of years ago, for my marriage, I am not able ejther to study or to go abroad. Since it is good for me to do both, expecially since they are your arrangements, I beg you, therefore, to send money back to support our family as 
well as to clear the debt to which I bear a heavy interest. Then I am able to study in accordance with your order. (See Letter No. 16 .)

Perhaps Hay planned to train his son to become a herbalist and thus to succeed his medical career at John Day eventually. But this did not become a reality, probably because Hay neglested to send money back for his son's passage.

It seems that Hay's wife did not dare to complain, as Lung on's wife did in her letter. This can probably serve as a hint that Hay might not have loved her much. And this can also explain partly why Hay never returned to his home.

Hay was such an eccentric character that, disregarding his own family's desperate condition, he often burned up the bills and checks paid to him from his patients. 29 If this was true, then he seemed to be a person not interested in money. It is also said that Hay was very superstitious. Very often he refused to go on a trip for patients in an emergency, if he thought that the date was not lucky or auspicious for making such a trip. Once he was taken by force, on a bright day, to a farm to take care of a sick man. 30 If there was a priest in the Kam Wah Chung Company for "Old General Chen," it must have bcen Hay. The religious notes all were written by him. He was the person in the Company who could recite all the verses of the 91 bamboo tallies placed in front of "OId General chen."

Smoking and drinking were Hay's hobbies. He lost his 
sight by drinking some brew which he thought was alcohol. 31 72 fifths of bourbon were found in the ceiling of the building, which was urdoubtedly hidden by him but forgotten later. They were distilled and bottled in 1913 and still sealed. None of the brands "Joel Frazier," "Old Mazeppa," and "Old Palmer" are on the market today. 32

In 1941, shortly after Iung on's death, Doc Hay's nephew, a young vian named Bob wah came to John Day with his family, as Hay's apprentice. Doc Hay died in 1952, at the age of 89 , leaving $\$ 2,000$ behind him. 33 Bob wah died in 1966, and the building of the company has been closed since then. Today only a Chinese lady, Lily--Bob Wah's widow--visits John Day occasionally from San Francisco.

Both Lung on and Ing Hay are buried side by side in the modern cemetery in John Day. Their tombstones, respectively, read; "Liang Kuan-ying [Lung on's Chinese name] 3.8631940, Hisin-hue, Kwangtung," and "Ing Yumien [Hay's Chinese name] 1862-1952, Tai-shan, Kwangtung." Beside them are the tombs of Bob Wah and his former wife.

The old cemetery is on the hill opposite the modern one. An informant said that once were buried there many Chinese whose bones were carried back to China in 1936.34 No marks have been left for today's visitors to trace. What one can find now are the tall weeds waving in the gentle breeze, and the wild flowers dotting here and there along the hilis. 
Floating above are graceful white clouds. Running below is the gurgling creek. The town of John Day lies prosperously at the foot of the elegant Blue Mourtains. Where is the shining yellow metal? Where are the industrious yellow people? Only a few pieces of tombstones and a clumsy stone building stand in the valley, that might tell the fragments of a forgotten story to inquisitors. 
FOOTWOTES FOR CHAPIER VII

$1_{\text {The Blue Mountain Eagle, January 3, } 1902 .}$

2 Interview with Harold Brent, Lung on's friend, 2940

N. E. 160th Drive, Barkerbrook, Portland, June 18, 1972 .

${ }^{3}$ A. W. Leedy's letter to the Chinese Consul at Washington, D. C. (See Appendix C for the letter); The Blue Mountain Eagle, April 21, 1905.

${ }^{4}$ Sam Galloway, "Rigid Tongs Blamed of Slow Adaptation of Chinses to Oregon," The Oregonian, February 15, 1953, p. 28 .

${ }^{5}$ Polly Nickean Bell, "A Pioneer Woman's Reminiscences of Christmas in the Eighties," Oregon Historical Quarterly, Vol. $49(1948)$, pp. 291-196.

6George Francis Brimlow, Harney County, Oregon, and Its Range Jand. (Portland, Oregon: Binfords \& Hort, Pibliskers, I951), pp. 180-181.

7 The Bl.ue Mountain Eagle, February $8,1901$.

${ }^{8}$ Ibid., February 23, 1901.

${ }^{9}$ Ching Wah Lee, "What Else for Chinese (but Lotteries)?" The Oregonian, November 1,1935, p.10.

${ }^{10}$ Allen Morrison, "No Chinaman's Chance Here," Oregon Statesman, Salem, Oregon, March 17, 1963.

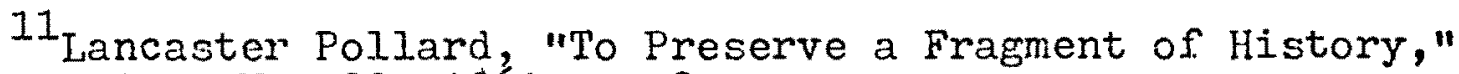
The Orgonian, May 22, 1961, p. 9.

${ }^{12}$ Corr aspondence with I. B. Weils, 2590 Street, Baker, Oregon 99314, April 13, 1971.

${ }^{13}$ The Blue Mountain Eagle, Febuary 15, 1901.

${ }^{14}$ E. R. Jackman and R. A. Long, The Oregon Desert (SAldweli, Idaho: the Caxton Preinters, Ltd., 1904), p. 148. 
15 The Blue Mountain Eagle, March 8, 1901.

${ }^{16}$ Ibid., February 26, 1908.

17"Orientals Going Home to Die," The Orefonian, September 3,1906 .

${ }^{18}$ Another name for China, called by the Cantonese, which was derived from Tong dynasty; they also called Chinese people "people of Tong."

p. 9.

${ }^{19}$ The Oregonian, November 19, and December 29, 1913,

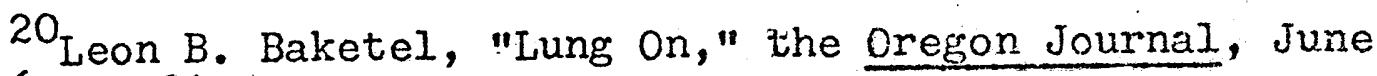
6, 1936, p. 21.

$21_{\text {Ibid. }}$

22 According to his tombstone, John Day cemetery.

${ }^{23}$ Interview with Gordon Glass, June, 1.6, 1971.

24 Oregon Journal, December 2, 1967.

${ }^{25}$ Ibid.

26 Interview with Harold Brent.

27 Ibid:

${ }^{28}$ Correspondence with Mrs. John W. Murray, P. O. Box 14, Dayville, Oregon 97825 , October $30,1971$.

${ }^{29}$ Interview with Bob Wing.

${ }^{30}$ Ibid.

3I Interview with Ralph A. Prose, Lung on's friend, 6205 Buena Vista Drive Vancouver, Washington 98661 , June 15, 1972.

32 The Oregonian, February 18, 1971. 


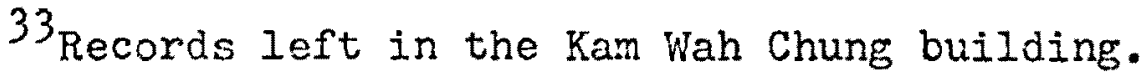
${ }^{34}$ Interview with Haro].d Brent. 


\section{CONCLUSIONS}

Throunghout her history China did not appear as a colonial nation such as Greece, Rome, and other European countries did. Chinese were generally known as a people unwilling to leave their homes for other lands. But on the other hand, when their very existence was jeopardized, Chinese would also throw themselves into dynamic migration movements, and even emigrated to other countries. To survive is the strongest, primitive desire of men, including Chinese. "Even the ant is afraid of perishing" is a common old adage. In China, at least four large scale movements had taken place from the end of the Sheng dynasty (IIII B.C.) to the end of the Ming dynasty (1644 A.D.). People moved from the Yellow River valley in the North to the Yang-tze River region, the Pearl River delta, Hianan, and Taiwan in the South. Some even emigrated to Korea, Japan, and Southeast Asia. The com-mon cause for these movements were wars.

The middle of the nineteenth century witnessed the unprecedent turmoil in China. The Opium War of 1839-1842 shocked its entire social structure from its old traditional foundation. The ensuing one-hundred-year history is a record of the invasions of external capitaiism which compounded the internal agony of over population, famine, and rebeliion. The victims vere the mass of the people. As for survival, a 
small portion of the most desperate from the province of Kwangtung emigrated to the New World, as well as to Southeast Asia.

For the first time the bulk of Americans met the orientals--an entirely different race with a heavy legacy of an old culture. Owing to the great demand for manual labor as well as cliriosity, Americans welcomed and applauded these queer guests from the other end of the earth. But very soon, misgivings arose among the whites as the cultural distinctions grew more pronounced in the course of interaction. More serious was the end of the need for chinese labor when the railroads had been constructed, the swamp lands drained, the forests cut up, and the white laborers arrived. Long before the rise of the anti-Chinese vave of the seventies, the Chinese had been attracted to oregon by its gold and other lines of employment. As the state stood comparatively still in the excitement of the eighties and nineties, Oregon became the shelter for thousands of Chinese, especially in many small towns in the bosom of the Blue Mountains. Here many tiny Chinese communities boomed and enjoyed their exceptional tranquility, and perpetuated their old life pattern. Nevertheless, their gold dream remained unrealized. Not many people were fortunate enough to strike gold from the residue left by the white miners. As employment was also limited, most of the chinese were compelled to return to China, and were as pour as when they came. Still a few 
lingered here, or moved to other cities but never went back to their native places. These people who paid no attention to the callings from their amilies and ancestors can be viewed as the indication of the beginning of a new Chinese emigration movement. For a new emigration concept was taking shape by degree during their on-and-off contact with the natives and the European immigrants as well. Contributing to their decision to stay here for good were also their vague comprehension of the well developed society of the white-stable, prosperous, free and easy. In contrast, were the extreme poverty and the persisting turmoil in thejr own country. Thus they shifted the sojourner's status to a permanent one. In this sense, they can be regarded as the spearhead of the fifth great emigration movement of the Chinese, which reached it height in 1949 , on the eve of the Communist takeover of China.

The community at John Day, Eastern oregon served as an example of this transition. The Chinese here made a trenendous effort to adapt themselves to this new scheme, from mining to shepherding, from a pure chinese grocery store to an American autonobile dealer, and from a Chinese herb doctor attending only to Chirese riners to a legendary physiciar opened to all patients and admired by the whites as well as by the Chinese.

Despite these endeavors they still failed to integrate themselves into the host society because of the unsurmountable 
barrier of culture and the wide breach of race. Thus the Chinese community at John Day remained isolated, and disappeared eventualiy as the dwellers moved away or diec. 


\section{BIBLIOGRAPHY}

\section{I.: Books:}

Bancroft, Hubert H. History of Oregon, Vol. II, 1848-1888. San Francisco: the fistory Company, Publishers, 1888.

Barth, Gunther P. Bitter Strength. Cambridge, Mass.: Harvard University Press, 1964.

Brimlow, George F. Harney County, Oregon, and Its Range Land. Portland, Oregon: Binfords \& Mort, Publishers: I9SI.

Coolidge, Mary Roberts. Chinese Imnigration. New York: Arno Press and the New York Times, 1909.

Delmatier, R. D.; C. F. McIntosh; and E. G. Waters, ed. The Rumble of California Politics, 1848-1970. New York: John Wiley \& Sons, Inc. $197 \%$.

Foster, John W. American Diplomacy in the Orient. Boston: Mifflin and Company, 1903.

Horner, Johin B. Oregon. Corvallis, Oregon: Press of the Gazette-Times, 1919.

King, Frand H. A Concise Economic History of Modern China, 181,0-1961. Praege: Pall IVII, 1969.

Lee, Rose Hum. The Chinese in the United States of America. Hong Kong: Hong Kong University Press, 1960.

Long, Reub A.; and Edwin R. Jackman. The Oregon Desert. Caldwell, Idano: the Caxton Printers, 1054.

McClellan, Robert. The Heathen Chinee. Columbus: Ohio State University Press, 1971.

Mallory, Walter H. China: Land of Famine. New York: American Geographical Society, 1926.

Meany, Edmond S. History of the State of Vashington. New York: the MaCmilian Co., 1909.

Michael; Franz H. The Taiping Rebellion.: Seattle: University of Washington Press, 1960.

Miller, Emma Gene. Clatsop County, Cregon. Portland, Oregor: Metropolitan Press, 1958. 
Paul, Rodinan W. California Gold. Lincoln, Nebraska: University of Nebraska Press, 1947.

Sandmeyer, Elmer C. The Anti-Chinese Movement in California. Urbana, Illinois: University of Illinois Press, 1939."

Schmid, Calvin F. Nonwhite Races, State of Washington. olympia: Washington State, Planning and Community Affairs Agency, 1968.

Scott, Ieslie M. ed. History of Oregon Country. Cambridge, Mass: the Riverside Press, 1924.

The Union Pacific Coal Company. History of Union Pacific Coal Mines 1868-1940. Nebrask: the Colonial Press, 1940.

Williams, Samuel W. The Middle Kingdom. New York: Paragon Book Reprint Corp, I966.

II. Articles:

Andrews, Wesley. "Baker City in the Eighties." Oregon Historical Quarterly, Vol. 50 (1949), pp. 87-89.

Blue, G. Verne. "Mining Laws of Jackson County, 1860-1876." Oregon Historical Quarterly, Vol. 23 (1.922), pp. 138-162.

Esvelt, John P. "Upper Columbia Chinese Placering." The Pacific Nortwesterner, Vol. 3 (winter, 1959),00. 6-11.

Hoben, Lindsey. "The Scourge of Famine in China." Current History, Vol. 34 (April, 1931), pp. 63-67.

Karlin, Jules A. "The Anti-Chinese Outbreaks in Seattle, 1885-1886." Pacific Northwest Quarterly, Vol. 39 (April, 1948) pp. 103-130.

Paul, Rodman W. "The Origin of the Chinese Issue in California." Mississippi Valley Historical Review, Vol. 25 (September, 1938), p. 181.

Power, Alfred; and Mary J. Finke. "Survey of First HalfCentury of Oregon Hotels." Oregon Historical Quarterly Vol. 43 (1942), pp. $264,269 \%$

Qiun, Larry D. "Chibl Chink Chinamen." Pacific Northwest Quarterly, Vol. 58-59 (April, 1967 ) p. 80.

Spaid, Stanley S. "The Later Life and Activities of General Joel Falmer." Oregon Historical Quarterly, Vol. 55 $(1954), \mathrm{pp}, 325,327$. 
Stone, Harry W. "Beginning of Labor Movement of the Pacific Northwest." Crezon Historical Quarterly, Vol. 47 $(1946)$, p. 155 .

Wilcox, B. P. "Anti-Chinese Riots in Washington." Washington Historical Quarterly, Vol. 20 (July, 1929), pp. 204-212.

Young, F. G. "Why Oregon has Not had an Oriental Problem." The Annals of the American Academy of Political and Social Science, Vol. 34 (I909), pp. 306-310

III. Newspapers:

The Blue Mountain Eagle, John Day, Grant County, Oregon. The Grant County News, Canyon City, Grant County, Oregon. The Oregonian, Portland, Oregon.

IV. Government Publications:

Department of Commerce Bureau of Navigation. List of Merchant Vessels of the United States, 1913, Washington Government Printing oftice.

U. S. Census Bureau. 9th Census 1870, microfilm Vol. 1, Grant County (334-663); Ioth Censeu I880, microfilm Vol. 2, Qrant County (1-280); Oregon Historical Society.

--n-. The Compendium of the Eleventh Census of the United states, 1890 , Part I--Population. Washington Government Printing office, 1892, pp. 36, 521. 


\section{APPENDIX A*}

LETTER NO. 1

An unfinished letter to a wife in China.

From an unknown husband, via the Kam Wah Chung Co., John Day, Grant:-County, Oregon.

Undated.

My Beloved Wife:

It has been several autumns now since your dull husband left you for a far remote alien land. Thanks to my hearty body I am all right. Therefore stop embroidering worries about me.

Yesterday I received another of yours letters, I could not keep the tears from running down my cheeks when thinking about the miserable and needy circumstances of our home, and thinking back to the time of our separation.

Because of our destitution I went out, trying to make a living. Who could know that the Fate is always opposite to man's design? Because I can get no gold, I am detained in this secluded corner of a strange land. Furthermore, my beauty, you are implicated in an endless misfortune. I wish this paper would console you a little. This is all that I can do for now...

* The original letters are at the Kam Wah Chung Co. building, John Day. The zerox copies of the letters are among the author's private possession, as well as avajiable at the oregon Historical Society, Portland, Oregon. 
LETTER NO. 2

From one of Doc Hay's uncles, via the Kam Wah Chung Co., John Day, Oregon.

To his parents in China. June 20, 1897.

Writing respectfully, beloved Parents, kneeling beneath at your feet, your prodigal son bey you do not worry about him. You will know I am well as you examine this message. It is I who wish you both health and strength, and every member of the family peace and safety. Enclosed is thirty dollars. Please check the sum. It is at you disposal. I have sent five hundred dollars early in December, last year, but so far I have not heard a single word from you. I am deeply worried as I have been waiting for a reply day after day. So please write me as soon as possible.

Do you still remember Shing-tsung? I have much trouble with this fellow. He makes up the story that during the past years you have borrowed a great amount of money from him but have never returned a cent. He tells everyone here this story from time to time, with such vivid details that all his listeners believe him and blame me on behalf of you. If it is true that you have borrowed from him during the 1870's, please give me a clear account so that I can arrange to return the money to him. The son is obliged to pay his father's debts, according to our Chinese tradition. Shing-tsung knows that I am eaining small wages, for I am working as a servant 
for an American. He habors a shameless desire to finagle the money from my pocket.

A few days agc, I gave four hendred American dollars to Wu Pang-ji to invest for me. Shing-tsung interfered, taking the money and investing it in the Quong Yuen Lung Co. He declared that money should be his, not mine. He also took four hendred American dollars from me more than ten years ago. My tearful pen is unable to record all the malice he has done me.

Recently I sent a letter to Wu Pang-ji asking him to return that four hrndred American dollars, or eight hundred. Chinese dollars, to you. [Wu Pang-ji must have been in China at that time--author.] If he does not have such money, go out and cut some branches from a tree and stick them in Wu's fields, so that we might take over his land in this way. Be brave, don't be afraid of him.

Your unlikely son,

Wen-teh

Yu-nien* My Good Nephew:

I have enclosed a letter, for my parents, please send it to Uncle Ii-nsio so that he might take it to my family. Please deliver it carefullu for me. I am worried about my parents, for I have not heard from them for an entire year, and I do not understand why.

*Doc Hay's Chinese names. 
LETTER NO. 3

From a mother in China.

To a son ai John Day, Grant County, Oregon. February 2, 1898.

Chin-hsin My Son, Take Notice:

We are all very well at home, so don't worry about us. But your Mother worries about you all the time. I cannot sleep and eat well because I am always thinking of you. You have been away from home for years. During that time, your second elder brother died, then your father died, and then your eldest brother died, too. Although I know that fate was the cause of their death, I still cannot but grieve deeply. I am old and weak now and I may die at any moment.

I hope you will be home and get married while I am alive, so that I might die with my eyes closed without grievance. I also hope that you will take care of Ah Fung, your nephew. Help him get a wife and establish their home, so that both your Father and eldest Brother might feel relieved under the ground.

You should save some money and should come back at least next year. I know my days are numbered. You won't see me any nore; I may already be gone by the time when you come back. Would you feel sorry then?

The twenty dollars which you sent me last June was received. So I guess you are all right and that relieves me a 
little. However, so long as you are not home, I am suspense. Come back, don't forget your Mother, Please.

Your Mother

\section{LETTER NO. 4}

From Lung on's father in China.

To Lung On, John Day, Oregon.

July, 1899.

Lung On, My Son:

Your business has proved profitless for a long time.

now. You should get rid of it or sell to some one else. Come home as soon as you can. Don't say "no" to me any more. There are too many gossips in our village that makes me uneasy. You are my only son. You have no brothers, and your age is near forty bui still without a male-offspring. You should think carefully. If you neither make a fortune abroad nor have a son at home, your loss is double. So why not come home before it is too late? Uncle Shang-sui has owned many businesses in Canton, you can choose a suitable position for yourself. Under his wing you can settle down and start your own business. A man who does not have any long-range plans should have an immediate goal. Since you cannot make money in one place you should try somewhere else. Be flexible in accordance with circumstances. You have been away from home for seventeen years, you know nothing about our domestic situation. Anyway you should return even only 
for a visit. Sell the business to some one else, this is the wisest. We need you, and you must come bach. I cannot tell you all that I have in my mind in this short letter. Come back, let our family get united and enjoy the rest of our lives.

Your Father, Chu-chia.

LETTER NO. 5

From Lung on's daughter, China.

To Lung On, John Day, Oregon.

September 6, 1901.

My Dear Father:

Prostrating myself at your knees, I write this letter and wish you health and well being.

Father, you have been abroad for so many years that you must have made a big fortune. But $I$, your humble daughter, am always thinking that I have never seen my Father. Last year, we--Grandparents, Mother, and I--have wishfully thought that you would come home, but we were all disappointed. Oh, Father, beg your quick return home. How thankful. I would be to God if I could see my father!

Father, you are now aged. Needless for your daughter remind you to come back. Please come back as quick as you can, and let the whole family get together again.

Your unfilial daughter, Ju-hsin 
LETTER NO. 6

From Lung on's wife, China.

To Lung On, John Day, Oregon.

Undated.

My Husband-lord:

I have received the two gold rings and ten dollars which you sent me via Mr. Wang. According to Mr. Wang, you are indulging in sensuality, and have no desire to return home. On hearing this I am shocked and pained. I have been expecting your return day after day. Your mother is completeIy blind. The housework is oppressing, and I have no one to give me a hand. If you have any conscience, please come back immediately. If you returned, all the hardships I have suffered would be nothing as compared to the rejoicing of seeing you on your return. But, alas, I don't know what kind of substance your heart is made of... Your daughter is now at the age of bethrethal and it is your responsibility to arrange her marriage... .

Your wife.

LETTER NO. 7

From Lung nn's uncle; China.

To Lung on, John Day, Oregon.

March 18, 1906.

Lung on, My Competent Nephew: 
I have sent you several messages when your mother traveled heavenward two years ago. And I also informed you many times that your father was heaven bound on June 6, last year. But I have not heard from you for years. Have you received what I have written to you? I think you must have received them.

Don't you remember the cld saying: a son is raised for the purpose of being companion to his aged parents. You have already failed to fullfil this significant duty, now you should come back right away to arrange the affairs left behind by your parents. Consider it carefully, my Nephew. Come back at once. After finishing what you have to do at home, it is you to decide whether to return to the United States or stay at home.

Your daughter, Ju-hsin, has been married for several year. Day and night, your wife is looking forward to your homecoming. In recent years, you have sent her neither messages nor money. This hurts her the most and she is heartbroken. She suffers illness continuously, and is as thin as a toothpick. If you have any soul, come home immediately.

Your Uncle,

Liang Chang-pei.

LETTER NO. 8

From Lung on's cousin in China.

To Lung on, John Day, Oregon.

February 24, [year?] 
Lung On, My Older Cousin:

What a long time it has been since you disappeared to a far-away country! Like Su who herded in the region of North Sea* for nineteen years, no one in the world knew where you were. Every day I wish to gaze upon your virtuous countenance but cannot; each time a colume of wild geese fl.ew across the sky, I think of you.** We are derived from one body, like hands and feet, yet have unfortunate fallen apart, one in the east, the other in the west. When will we see each other again?

The conditions of my uncle-parents' [Lung on's parents] health seem all right, but they complain very often. Their clothing is getting heavier and their appetites smaller [it means they were getting older and weaker.] Uncle [Lung on's father] suffers from rheumatism, and Aunt [Lung on's mother] poor eyesight. My sister-in-law [Lung on's wife] is well and busily waiting on her parents-in-law, but sighs constantly over her loneliness and desolation. Niece [Lung On's daugh-. ter] is getting along well with the needlework and is learning a few lines of classical poems and inscripture, but she

* Su Wu was a hero in the Chinese history. He was dispatched as an envoy by the Han dynasty in the year of $100 \mathrm{~B}$. C. to Hsiung-nu, a strongest nomadic nation on the north. Hes was detained and sent to the Pei Hai [Lake Baikal, Siberia]. by Hsiung-nu. After herded sheep for nineteen years there, he finally got back to Han.

**Wild geese are used to flock together and never separate themselves. When they fly, they arrange themselves in the formaticn of one straight line or in the shape of " $A$ ", an inverted "v:" The Chinese use them to describe brothers 
is still unbetrothed.

Our countryside is peaceful and quiet, at least for the present, and without flood and drought. Banditry takes place here and there but has not come to our village. Only inflation troubles us. Prices rise and everything is expensive. One hundred more yuans are not enough to meet the daily expense for a year for my family, even though I spend them cautiously and frugally. Although Uncle had small savings a few years ago, it now must have been dried up, as you have not sent money back for a number of years. I am afraid that pretty soon he will face the urgency of brow-burning if you still do not send some back to him.

I do not mean to blame you for not sending money back, because I understand that might not have been lucky as to get enough money, but. I really cannot figure out why you do not write home. Neither can I see why you do not like to come back.

You are not young any more. You should be free from youthful confusion now. You do not have much time left for fooling along. You have neither wealth in you hand, nor a son playing in front of your house, and you seem still to lack ambition. You can achieve alj. by merely coming home. In addition, you can bring about the unity of your family. Your parents are now in the hours of sunset, feeble and fading, and constantly suffuring various sicknesses. If you delay coming back, anything can happen to them.. Then, I 
wonder, how could you return them the benevolence they bestowed upon you the form of raising and disciplining you?

By all means, you should pack and come back right away. No "forfune" can last long; no flowers can bloom forever. Time flies like an arrow; tides wait for no men. If you do not come now, you will miss the golden chance both for striving for future and for your family. And you will regret forever.

$$
\begin{aligned}
& \text { Your younger cousin, } \\
& \text { Yung-che. }
\end{aligned}
$$

LETTER NO. 9

From Lung on's cousin, Hong Kong.

To Lung On, John Day, Oregon.

September 13, [year?].

Lung on, My Cousin:

I, your younger brother, am now working at Yu Fa's Silver Shop, Win-lu Street, Hong Kong. This was by the arrangement of our Sixth Uncle, since he is the boss of the shop; and $I$ act as his representative.

I have written you a letter some time ago, but I don't know whether it has reached you or not. Your father is old and feeble. Your mother has been blind for a couple of years. Pack your trings and come back after you peruse this paper, so that you can please your beloved parents, as well as sooth your wife. You are in your forties, [you must know what you 
are obligated to do.] After you have been home you still can go back to America. No one will stop you., Why then have not delivered home any message?

This letter is written at your mother's reguest, so forgive me if I offend you.

$$
\begin{aligned}
& \text { Your cousin, } \\
& \text { Kuan-chang }
\end{aligned}
$$

LETTER NO. 10

From Lung On's cousin; Hsin-ji Li, Hsin-hui District, Kwangtung, China.

To Lung on; John Day, Oregon.

March 4, 1905.

My Dear Elder Cousin:

It has been years since we departed from each other.

I hope your business is prosperous and everything is as well as you desire.

I have been unemployed at home since I left America. To sit and waste food is what I can do now. This is so disastrous that even a mountain of gold would be used up. Therefore, I am planning to go back to the United States again, to see if there is a chance for me.

Two years ago, your mother passed away. Last year you: daughter got married. Your aged father is immobile. He will pass away any time now. Your wife feels left out and hurt. Even the neighbors are touched by her sadness and misfortune. 
Come back as soon as you receive this message. If you don't, you should send money home for their living expenses.

Your cousin,

Liang Kwan-jan

LETTER NO. 11

From Lung on's cousin, [United States?]

To Lung On and others at the Kam Wah Chung Co., John Day.

February 7, [year?]

My Brothers:

I am shocked by the message from Lung on that our friend, Kung-lin, was shot and killed by an American. What a disaster! How sad! Enclosed is \$30, I am sending it to help with the expenses of his funeral. I feel guilty that I am unable to offer him more money, for my luck has been bad. This money is only a token repayment for his kindness to me, and I wish him much peace beneath the earth.

Sincerely yours,

Kwan-chi

LETTER NO. 12

From Doc Hay, John Day, Oregon.

To his cousin, [in United States?]

September $25,1895$.

My Esteemed Brother, Yu-po:

May your business greatly progress, and your ambitions 
be totally achieved so that you can set up the date for an early home-return. These are our wishes for you.

You must still remember the gold ring which you took from our store when you left John Day a couple of years ago? That was Huang Liang-wen's, not ours. In order not to harm the friendships among all of us, I should get the ring and return to him. Therefore, please tell me where you have mortgaged it so that $I$ can redeem it.

one thing you might be interested to know is that we are going to remodel the temple and change the clothes for the Buddha. Donations are coming from all directions. I don't know whether you have offered your share while you were here. If you didn't, please send me immediately the money you would donate so I can list it for you.

Speaking of our business, it is very hard for us to keep the store open. The New Year is approaching, but we still don't have the merchandise for sale. My partner Lung On, while he was on his way to procure some goods, lost all our money in gambling with Americans in Portland and Baker. That is why our store still lacks of groceries. But please don't let others know, lest they would laugh at us or not believe it. If you have spare money, please lend us forty or fifty dnllars for procuring some commoditties from Portland. I will repay this loan to you at the time you go back China. Your younger brother, Ing Yu-nien [Doc Hay] 


\section{LETPER NO. 13}

From Doc Hay, John Day, Oregon.

To his uncle in the United States. November $25,1895$.

Hung-shen, My Most Esteemed Uncle:

Descenting from the same lineage, I will forgo custom and speak directly.

Living in the inland [Idaho?], you must have succeeded both in business and in reputation, needless to say that you must have already acquired plenty of gold and silver for an earlier home return. We fellows in John Day, being your nephews, also share your success rejoicingly.

From your prvious letter, I find that you still delay in this country. You told me, however, in your letters, several times that you were packing and purchasing the ticket for home, and I entirely believed it. Why then have you changed your mind? Anyway, I advise you not to rely too much on gold, but ought rather to return home early. The wisest course is to get married and settle down at home while your parents are still alive.

Now, in our place, the temple is to be remodeled and the Buddha's clothing, to be changed. Every member here donated heartily and excitedly. All the projects are to be finished by New Year. If my Uncle, you, is among those who have not donated yet, then please by all means send it soon. 
If you do not hurry, you will lose the opportunity for offering.

Your nephew,

Ing Hay

LETTER NO. 14

From Doc Hay's father in China.

To Doc Hay, John Day, Oregon.

April 9, [year?]

Yu-nien My Son:

Time slips fast. I have been home for several years since I left you. I recall at the time when I was buying the ticket for returning home I determined to buy one for you, too. But you did not agree on that. You asserted "Let the Ola return home; let the young stay abroad to make money." You were 100 percent right!

I don't blame you that you did not sent money back in the first years because I consider that you might have encountered hardship at the beginning. But now things are quite different. You have fortune at hand. Normally, you should have come home to see your mother and wife, even only for a visit. Then, a few years later, you could return to the United States again. But who could believe that you had never sent back anything, neither a penny nor a word. I have written you many times to ask you send a little back twice a year. So far the only thing I have got from you is 
"disappointment."

Don't you know that to mail a letter to you $I$ have to spend hearly half dollar. N.w we are in such bad condition, where can I find half dollar for the postage? You, in America, have liquor to drink, and meat to eat, so you no longer remember that we are still starving and cold.

When you receive this message, you should in any case think to come home.* If not, send money back. If not, either, write a letter to your wife. Do not let us to be laughed at by others.

\author{
Your father, \\ Ing Du-hsio
}

LETTER NO. 15

From Doc Hay's father; Hsia-pin Li, Tai-shan District, Kwangtung, China.

To Doc Hay; John Day, Oregon.

May 28, 1903.

Take notice, my son,

You have been away for more than a decade. Men go abroad in order to earn money to support their families, but you have not sent us money or letters since then. Everyone at home is anxious and worried, even in their dreams. I am

*Hay's father did not understand that restricted by the law of the United States a Chinaman who left here was not allow to come back again. That was why Doc Hay and Lung on did not like to visit their homes. 
disturbed and confused. Are you intending to let us starve to death? If you had sent no money back because of your bad business then I would not blame you. But I have been told that your business is booming, and you have made much money. Why don't you send some back? Even if you don't think of your mother and me, you should think of your wife and son. But you think only of yourself and enjoy your life alone without considering us. This is not suitable for a man of high character.

I remember what you had said when we were both in the Golden Mountains. You said, "Let the old go back home and rest. Let the young seek fortune abroad." You were exact]y right when you made that remark. I have been back, and you have sent no money. Prices are sky-rocketing here, everything is expensive. I dor't have any income, since I am unemployed. The small amount of money which I had brought back from Golden Mountains is gone. I am planning to borrow bur there is no door to knock on. We are in a desperate situation. We cannot get along any more now. My grandson-your son-is growing up and needs schooling. The tuition fee is much more than living expense. Your mother is approaching the age of sixty. Her birthday is in Augast. Of course, you know the date. Are you going to express what a son should for his mother on that day?

Send some money immediately to meet the urgent need at home. Come back whenever you can get a little fortune so 
that would bring about our family's reunion.

\author{
Your father, \\ Ing Du-hsioh
}

LETTER NO. 16

From Hay's son in China.

To Hay, John Day, Oregon.

May 12, 1916.

My Greatness:

Every individual of our family is healthy, so I hope your Greatness, while living abroad, will not weary yourself of us, but only take care of yourself and make your body robust, to receptive to luck and frotune, so that you may soon obtain gold and silver and sail homeward.

These are the earnest wishes on the part of your son.

Yesterday Uncle Yu-po arrived home. He gave me your message that I might go to the Gold Mountains if I could first study for two years. If this is your will, your son, I, is greatly delighted. But considering the privation of our home, plus the fact that I am still in debt to others three hundred dollars which I borrowed a couple of years ago for: my marriage, I am not able either to study or to go abroad. Since it is good for me to do both, especially they are your arrangenents, I beg you, therefore, to sent money back to support our family as well as to clear the debt to which I bear a heavy interest. Then I am able to study in accordance 
with your order.

Since the time when your Greatness went abroad in search of fortune, we father and son, have never seen each other. Please come back to visit our home once, no natter.how little money you have made, before I can get to America.

I have been working as a farm laborer for many years, and have also been a tenent of a small puddle field. This is the way I try to support our family. I report this in the hope that your Greatness may comprehend a little of our hardship.

$$
\begin{aligned}
& \text { Your son, } \\
& \text { Sie-shao. }
\end{aligned}
$$

LETTER NO : 17

From Doc Hay's son in China.

To Lung on, John Day, Oregon.

May 1916.

Dear Uncle Lung on:

I have heard from home that you and my father are intimate friends. So I won't be so embarrassed to tell you something about myself. My condition here is very difficult. I am not an able youg man, and since I have married I owe a great debt to others. My father has sent neither money recently nor messages for years. So I would bother you, Uncle, to remind my father to send a little money home in order not to desappoint my mother and me. Your kindness would be 
appreciated very much.

Your Nephew,

Ing Sie-shao

LETTER NO. 18

From Doc Hay's cousin, China.

To Doc Hay, John Day, Oregon.

September 28, 1903.

I-Nien [Hay's Chinese name,] My Dear Cousin:

Each person of your family is well. You have nothing to worry about from far ; away.*

It is high time now for an absent son to exert himself, therefore, to achieve something. Yesterday a compatroit came back from the same place you stay. I asked him about you. I was extremely pleased when he told me that you were in an extraordinarily well-off condition. At the same time I am puzzled why you have sent home neither gold nor letters.

At the present, prices go up. The cost of rice is as high as that of pearls, and firewood as dear as cassia. Your home is in a desperate condition beyond describing. The moaning of your ramily from the cold and crying from hunger can be heard frequently.

This spring I have lent them some money when I found

* Like many other writers of the letters coljected here, this writer was also fond of piling up the usages or idioms which were contradictory to what they were going to say later. 
they were going to stretch hands to beg from door to door. I note that since our great-grandfather, no one in our family had been seen in such barefaced shame as to beg.

That small amount of money borrowed from me must have been used up. If you do not send money back, they will probably have to embark upon the road of begging. I am unable to help them any more although I intended to, for I myself am not in a good situation, either.

Your son is coming to the age of marriage. Now I hear that you have such wonderful means to make living, why not remit money back right away?

What reason prevents you from sending money back? According to the words of that returned compatroit, it is not difficult for you to send back three or five or even seven thousand dollars home. Anyway, the more the better, for the surplus money may be used to invest in some business. Then you can live on it for the rest of your life when you retire from abroad.

$$
\begin{aligned}
& \text { Your elder cousin, } \\
& \text { Ing I-tung. }
\end{aligned}
$$

LETTER NO. 19

From Doc Hay's cousin in China. To Doc Hay's, John Day, Oregon. May, 1903. My Most Esteemed Cousin I-nien, 
We, as closely related as hand to foot, are separated by so great a distance that even the swan and fish could not carry the messages for us.

You left your homeland a dozen autumns ago. I have been thinking that things must go well for you. I have heard recently that you possess the mighty power of turning the heaven and upsetting the earth with your medical technique, and are looked up to as the greatest among all physicians. No doubt, then, you must have made a great fortune, for profit always goes with fame. How your family will be enriched by your accomplishnent when you come back. But their situation now is thoroughly wretched. You are a son, a husband, and a father, and your parents, your wife, and your children depond upon you. Why not, then, send money back now so that they won't endure starving and shivering?

My brother and I are almost idle at home, as if our hands were bound. I tutor sometimes, but I hardly make a living for the present, nor have any hope for the future. Therefore, I aspire to seek my fortune abroad to support my family. But I am unabie to take any action, for I cannot afford the fare for the passage, nor can I find a source from which to borrow. Furthermore, I don't have any brother abroad to render me the needed assisiance. There seems no way for me to escape this country. Only you, my cousin, have the ability to help me because of your excellent conditions there. I pray that you will extend a hand to elevate me. 
I have sent several letters to you, but received not a single word from you. It seems you are too apathetic. Please answer me soon this time.

$$
\begin{aligned}
& \text { You cousin, } \\
& \text { Pei-chin. }
\end{aligned}
$$

LETTER NO. 20

From Doc Hay's cousin, Astoria, Oregon. To Doc Hay, John Day, Oregon. September $18,1901$.

Dear Cousin:

It has been two years since the last time I saw you at Salem. I think you must have made a fortune, broken the habit of smoking, and your health must be fine.

I started a herbist shop with Fon-yao in Astoria late March. But we did not know that the Astorians were not interested in the use of Chinese herbs. The business was so bad that we was forced to close. Now Fon-yeo is geeting along quite well in Baker City: I intend to go there, too, but do not know how to get there. So I am planning first to get to your place first.* What is your opinion? Please reply.

$$
\begin{aligned}
& \text { Your cousin, } \\
& \text { Ing Yoa }
\end{aligned}
$$

*The real purpose of this letter was obviously the intention of the writer of coming to John Day to live with Doc Hay. 
LETTER NO. 21

From Lung on, Baker City, Oregon.

To noc Hay, John Day, Oregon.

November $26,1910$.

Hay, My Old Partner,

The American lady whom you have treated the other day says that the part beneath her left breast still pains occasionally, and the color of it turns to blue when it pains. Tell me what can I do for her. Send me the medicines and the way of using them.

\section{Lung on.}

\section{LETTER NO. 22}

From Doc Hay's uncles, Walla Walla, Washington.

To Doc Hay and other, John Day, Oregon.

october $22,1900$.

Yu-po and Yu-rien*, Our Two Nephew,

Yesterday we were informed by a note from our Grandfather that the tomb of our great Grandfather is being rebuilt so' that his descendants might be prosperous. Each member at home is going to contribute from four to six dollars, but the money is still not enough so we fellows in America should offer our shares. Some of us will donate twenty dollars, some,

$$
\text { *hay's Chinese name. }
$$


ten dollars. Please send your offerings to Walla Walla and we will send them to China. Don't neglect it, it is a matter of importance.

$$
\begin{aligned}
& \text { Your uncles, } \\
& \text { Tien-mo, Yuan-chung, } \\
& \text { Tse-hsioh, Hsioh-hu, } \\
& \text { and Yu-ben. }
\end{aligned}
$$

LETTER NO. 23

From a friend, Mount Vernon, Oregon.

To Lung On, John Day, Oregon.

October 5, 1903.

Lung On, My Respected Friend,

I write you this note in order to know whether you have sent out the merchandise which I ordered yesterday. They are cigarette and candies. If you have not yet, please send them immediately by express!

By the way, Betty--John William's [?] daughter--is now working in my shop as a cook.

$$
\begin{aligned}
& \text { Sincerely, } \\
& \text { Markie Tom }
\end{aligned}
$$

LETTER NO. 24

From a uncle in [the United States?]

To Ah Hsiang, John Day, Oregon.

April 18, 1896.

We haven't seen each other for several years. I guess 
everything must be very well, and that you must have made millions. Are you ready for a gloricus home return? Indeed, you are. Let me congratulate you first!

Referring to the entanglements between Ing Pang-chi and Wu Fan-chang, everyone of our countrymen here and the Americans, too, all think that Pang-chi is evil and vicious. He intentionally took away all the business and merchandices, plus all the money, from Fan-chang. No one who is aware of the treacherous way which Pong-chi treated Fan-chang will not shed tears and gnash teeth.

By the invitation initiated from Pang-chi, I tried to arbitrate their quarrels. But all my efforts were in vain when he realized that my manner was fair to both sides, but not in his own favor only. He defied my settlement and continues his presumptususness and outrageousness. In short, he calculatedly usurped the possessions of Fan-chang, whom he thinks is tamed and easily deceived. He agitated amorg the Ings--his brothers and cousins--to be against me and defamed me with malicious slander that I was bribed by Fan-chang. But your uncle, I, only has one idea in mind--to serve the. two parties righteously and justly. I can stand straight in the presence of ghosts and gods. Thankful to heaven and the just American officials that Fan-chang's lawsuit has been accepted by the Court. They all believe that the acts of Pangchi are unlawful. Now the judges decree everywhere that whoever catches him will be awarded on hundred dollars. I, hereby, inform you, my capable nephew, that if you run across 
him, show him the decree and seize him immediately. All the expenditure you spend on it you will get back from wu Fanchan. You can also get the award of one hundred dollars at the Court of Canyon City, I assure you.

Your uncle,

Tsung-wen 


\section{APPENDIX B}

\section{SPOKANE DRUG CO. WHOLESALE DRUGGISTS SPOKANE, WASH.}

Mess. Kam-Wah-Chung \& Co.,

Nov. 13, 1903

John Day, Ore.

Gentlemen:-

We send you 2 Ibs. Gum Opium to-day registered mail at the price we quoted you, $\$ 3.90$ per pound.

We have also sent a tracer out for the whiskey. We do not understand why it has not reached you before this time. We hope you will receive it very soon and if for any reason you do not, let us know again and we will send another tracer after it.

Yours truly, 
STILIMAN, LEEDY \& PIERCE, LAWYERS

Canron City, . . Oregon.

To the Hon. Chinese Consul, Washington, D. C.,
W. M. PIERCE

A. D. LEEDY

A. D. STILLMAN

June 20, 1905.

Dear Sir:-

On or about the 17th day of April, 1905, a number of citizens of the United States of America in the town of John Day, Oregon, without a warrant or any process of law, went into the part of the town occupied by the citizens of your country, wrongfully entered their buildings in the night time at about 11 o'clock, searched and ransacked the buildings, carried off some of their drugs and medicines and forceably arrested one Ah You and one Ah Poo took them into the town of John Day, threw them in jail where they were kept the remainder of that night the next day and the next night. on the 19th day of April those two men were released without any examination or process of law whatever, and a warrant was sworn out for three other citizes of your country upon the charge of having opium in their possession. Along the articles which were taken upon the night of the 17 th was a small quantity of opium and some opium pipes. Two of the men arrested under the warrants issued on the 19th plead guilty to the charge of having opium in their possession and one of them a Chinese merchant, "Lung on," plead not guilty, stood his trial and was acquitted by a jury in the Circuit court of this county, myself acting as his attorney in the case.

At the time that this mob invaded these premises on the night of the 17th of April, as before alluded to, this mob ordered all Chinamen to get out of town by the first of May, but these men have valuable property interests and will not go until their interests are disposed of or their financial interests protected. This is in accordance with my advise to them.

I believe that the rights of the citizens of your counhave been invaded in this matter, but do not think that justice could be obtained in the local courts, and believe it to be for their best interests that the case should be taken up by your Government in our Federal Court. The testimony is conclusive that these people acted without any warrant or process of law.

I would be very glad to hear from you in this matter and in case that you see fit to take up the matter I am in a 
position to represent your Government, and the citizens thereof in this county, in the Federal Court in this state.

I write this letter to you by request of lung on and Ing Hay, prominent members of the firm of Kam Wah Chung Co. in this county, and men who have lived here about 17 years and arè well and favorably known in this county.

I trust that I may hear from you in the near future and will be very glad to furnish you any information you may desire in this matter.

Yours very truly,

A. D. Leedy (signature.)

Dic.-A.D.L.-K. 
Figure 1. The building of the Kam Wah Chung \& Co. 


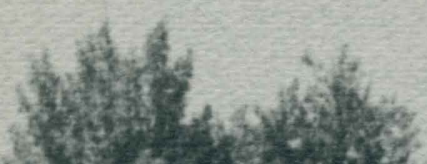

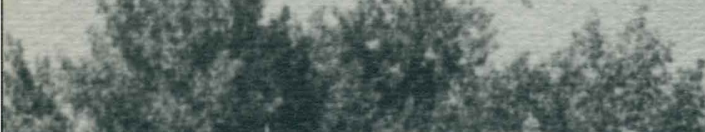

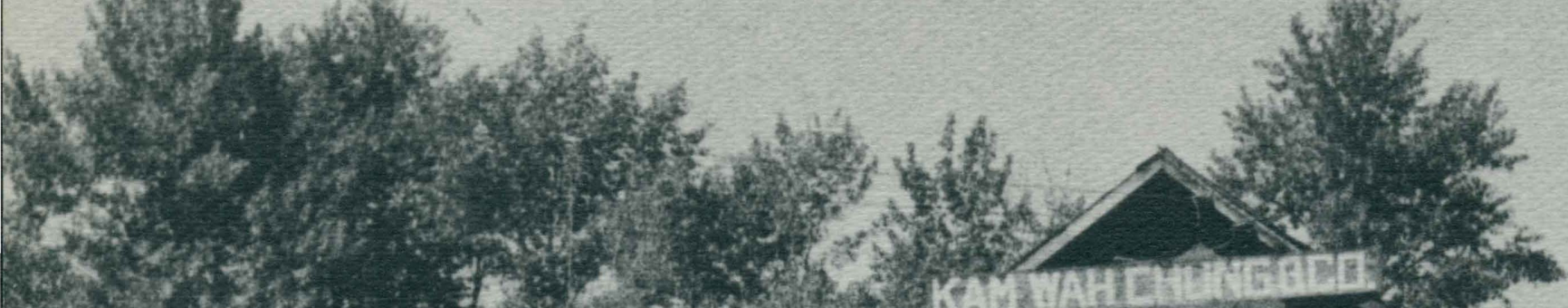

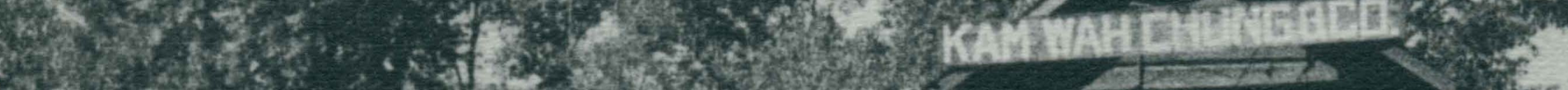
S. Wixt.

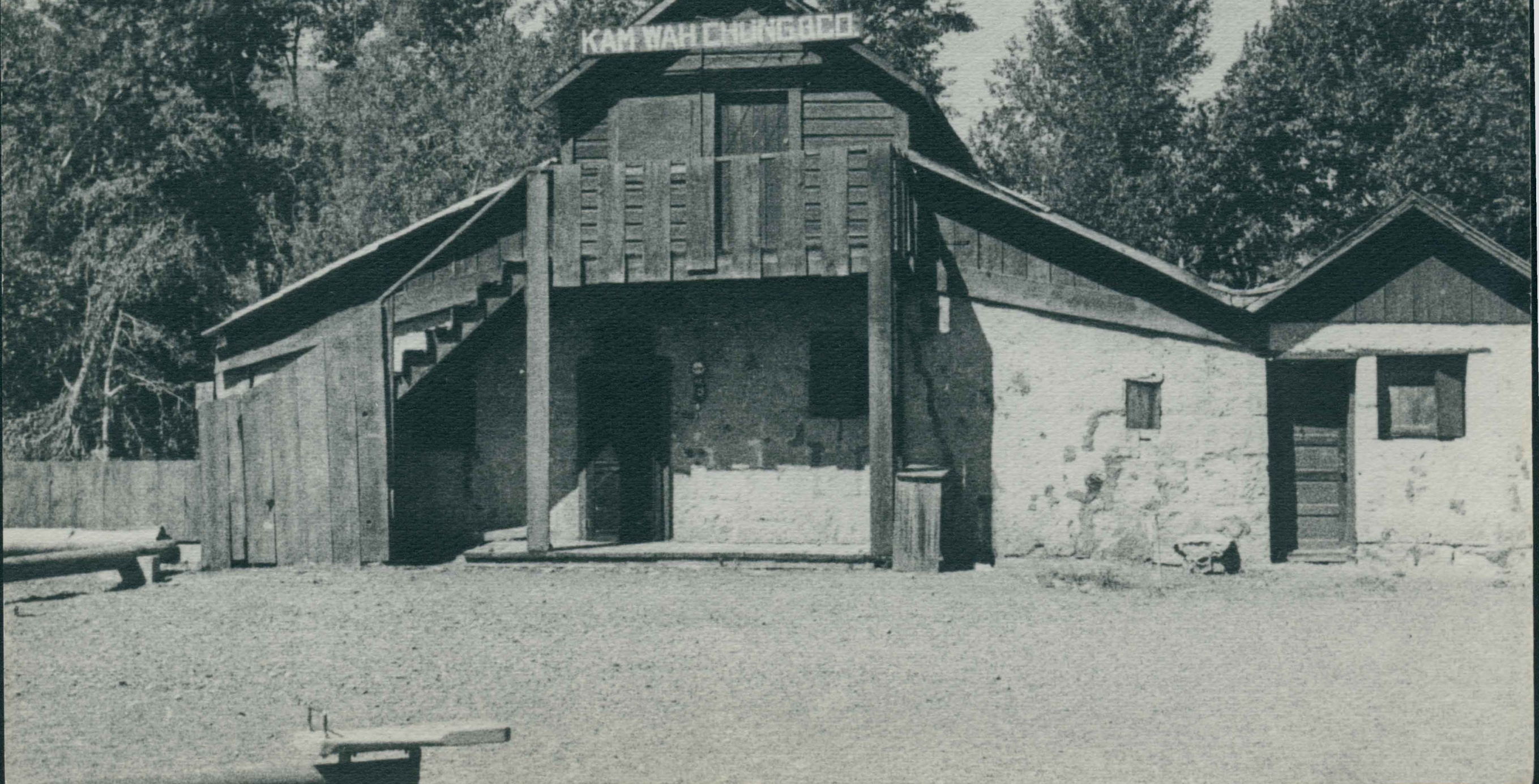


Figure 2. Lung on (on the left) and Doc Hay (on the right). 


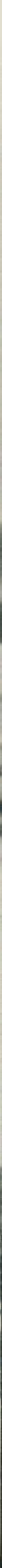


Figure 3. Doc Hay in his twenties. 


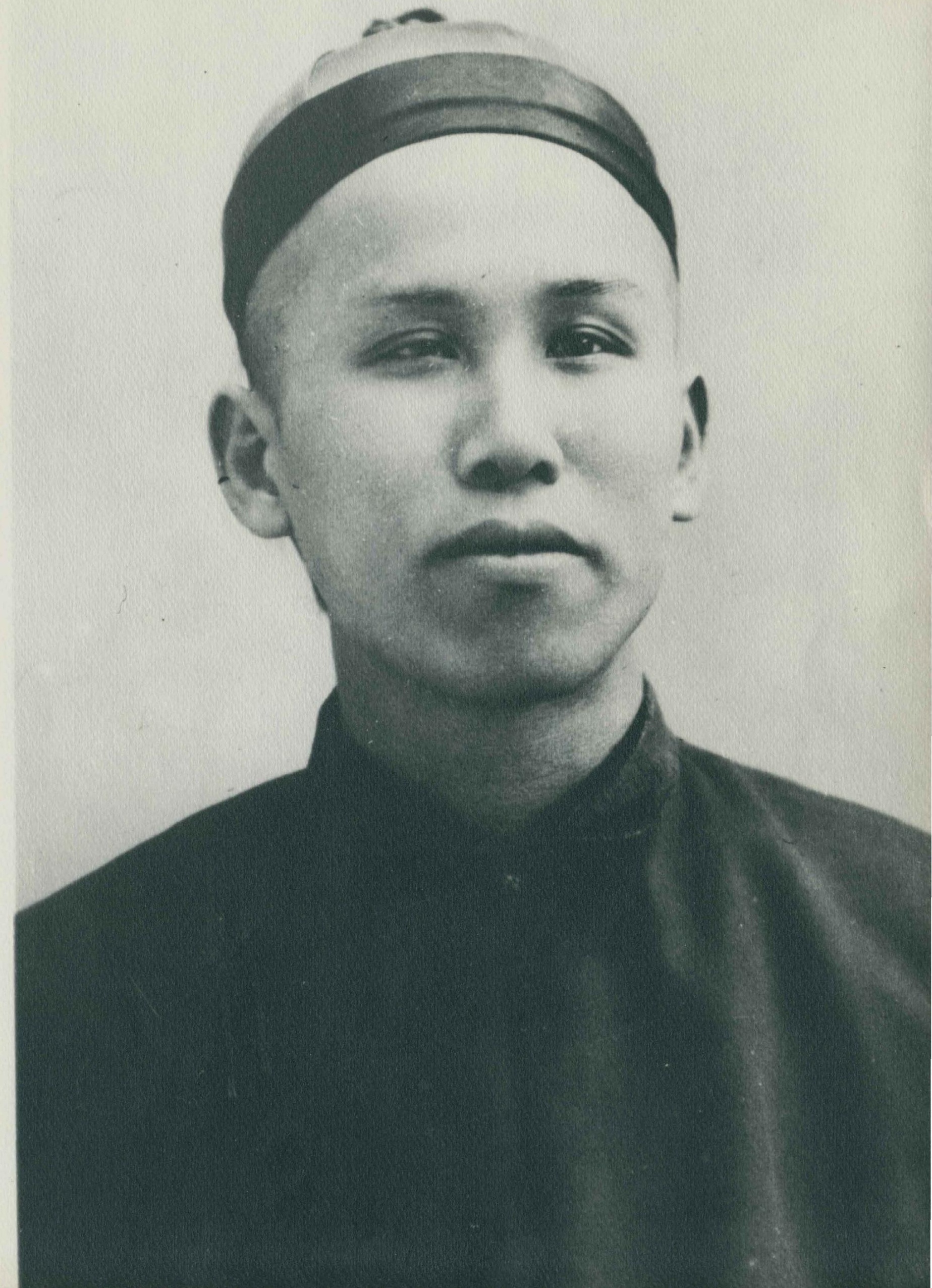


Figure 4. Opium pipe (on the center of the table). 


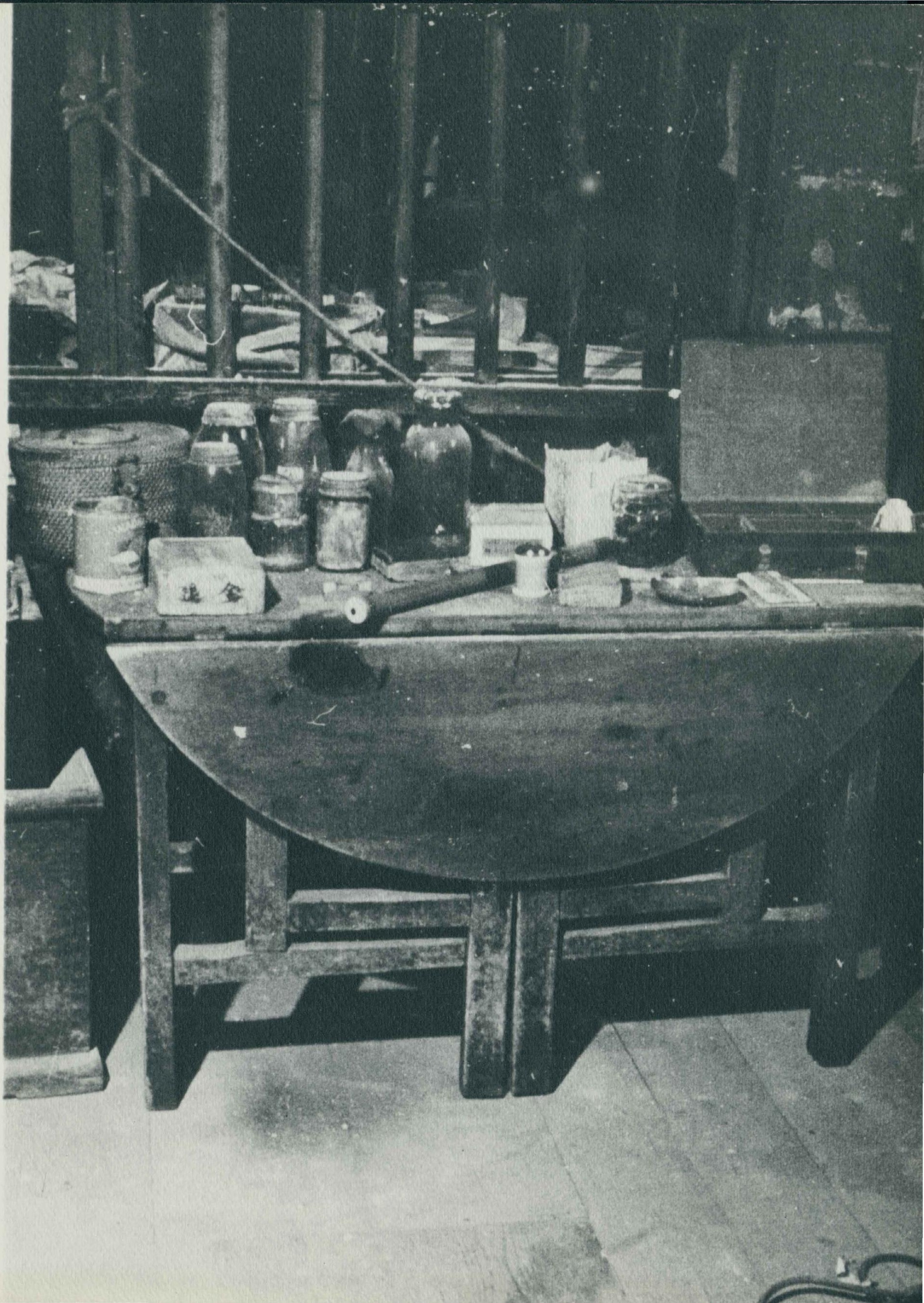


Figure 5. Doc Hay's berb room. 


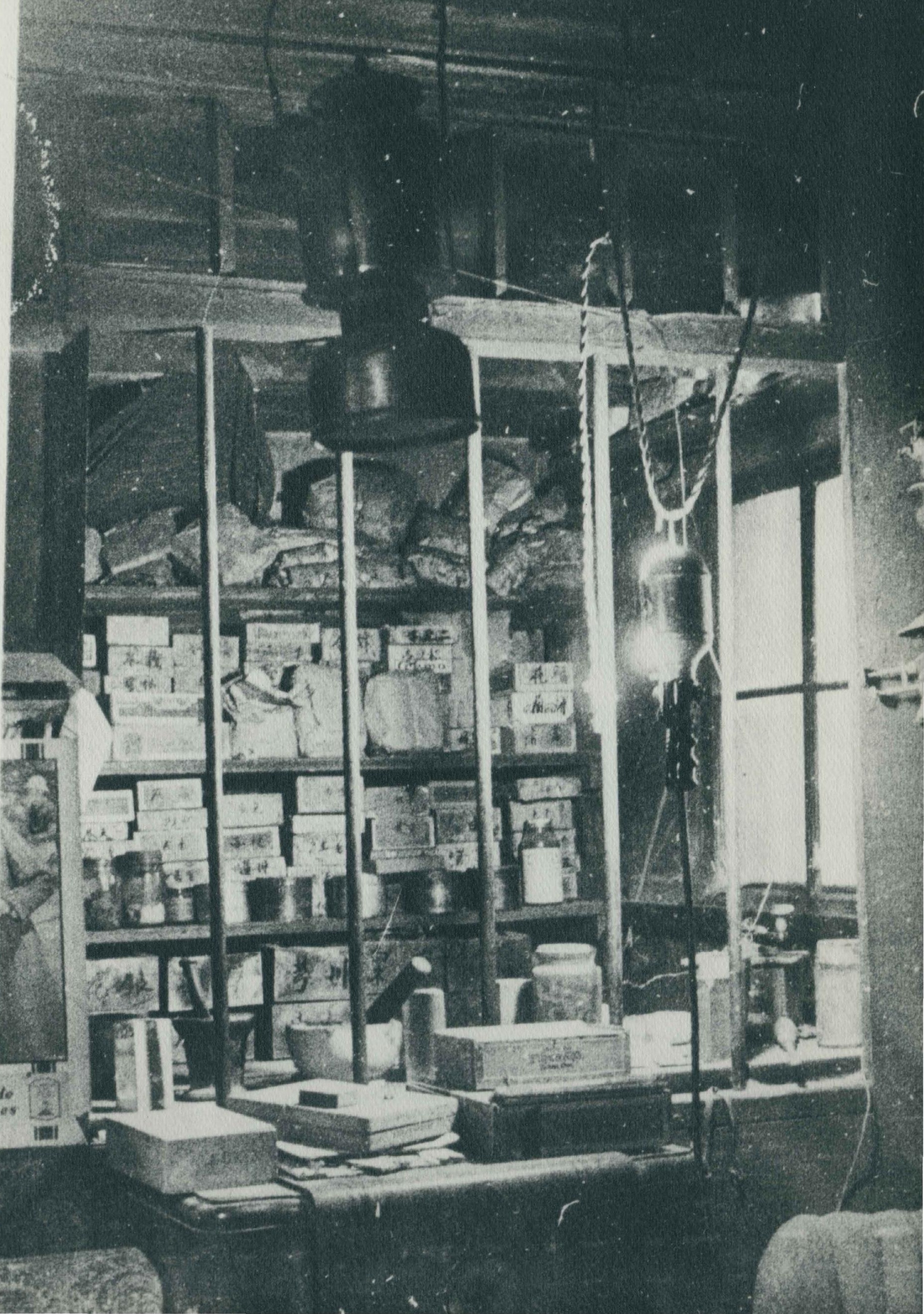


MEDICAL HERBS GROCERIES

CHI. JESE GOODS GENERAL

MERCHANDISE
OFFICE OF

\section{Kam Wah Chung \& Co.}

ESTABLISHED 1871

Grant County

JOHN DAY, OREGON

J. K. Smith C.O. rortiand, ore.

Gentiomen:

lease find our check fil7.II to cover the 2

bills Aug. 2 ind 3 .

We hes been give Mr. Stoner sore ciger

he froret put them in ve thourn vou was short in stock.

You cen put in tris new order for us.

5 (M) Caesterfield 3 (M) Dorino

3 k) Hil. Mormis a in) Wines

5 (M) Sensztion 300 Eed Dot Fanetles

Yours Iruly,

Kem Wan Chung Co. 200 Wodangl Tudue

Figure 6. A business note with the date of the establishment. 
KAM WAF CHEING CO, - DEALEzs in -

GRORERES, TEA JAPMESE ROORS

Fire Crackers, Silk Handkercheifs tic.

- it at Lowest Prices.

JOHN DAY CITY, - (Grant County) - OREGON.

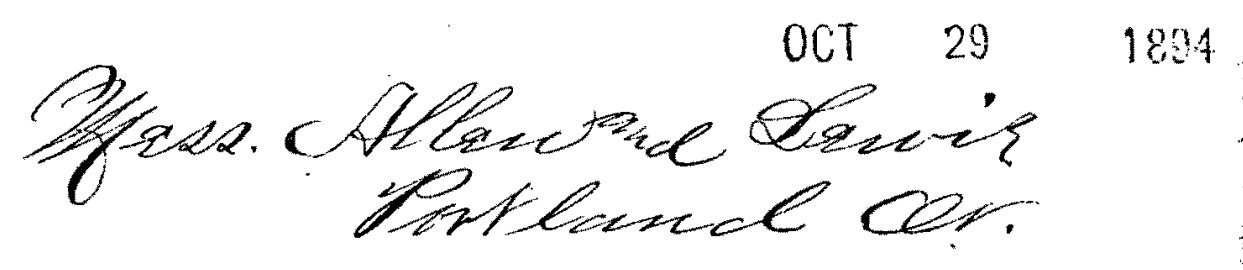

Dearshir

sele hape you Plecese thy

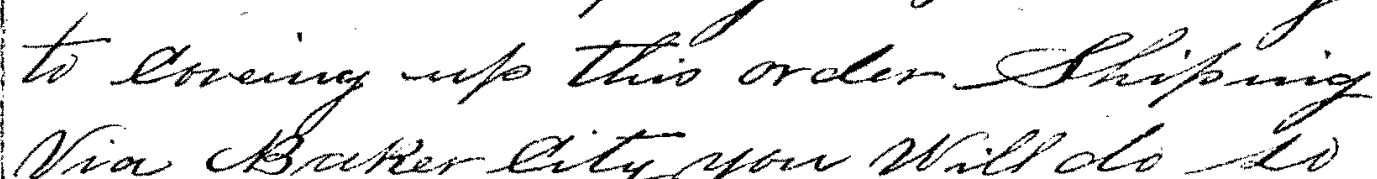

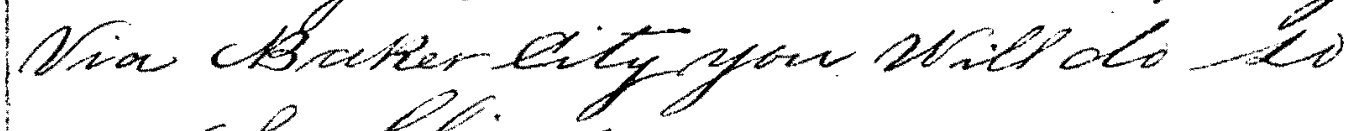
muth obliged

Dewno Reapectyoly, Trow diath ibumed.

10, 2ack. D. Slongor

5... E. C. D. $10 \mathrm{~g}$

3 Chutt B. CA. Snce

5 chof White thraion edrop.

5 - Ming of the weat -..

1 - Mlue Soint Gyster 1 lo van

3 - Candles 16 o.

50 elo. Arbuercles exffoe

2 tiv chatcher

Figure 7. Japanese goods. 


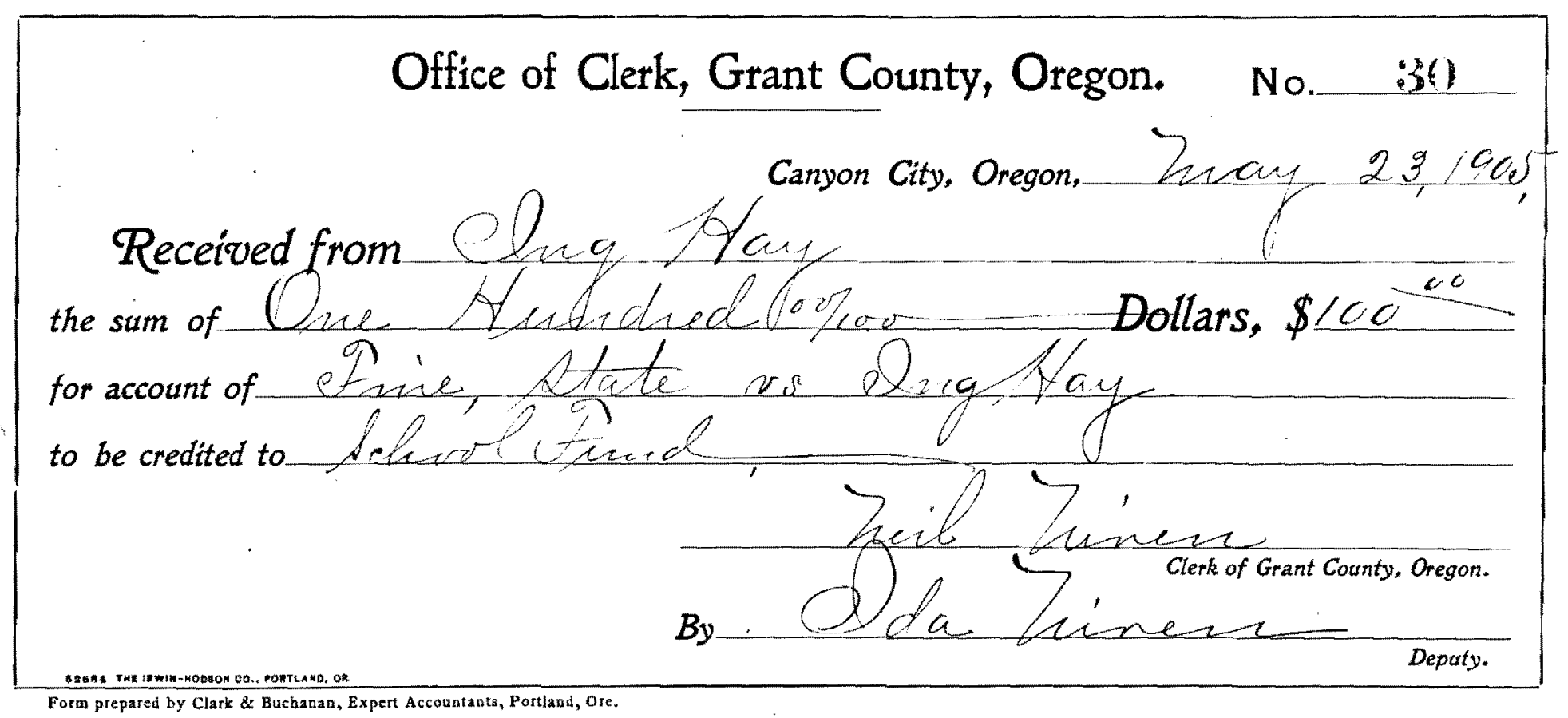

Figure 8. The receipt of a fine. 


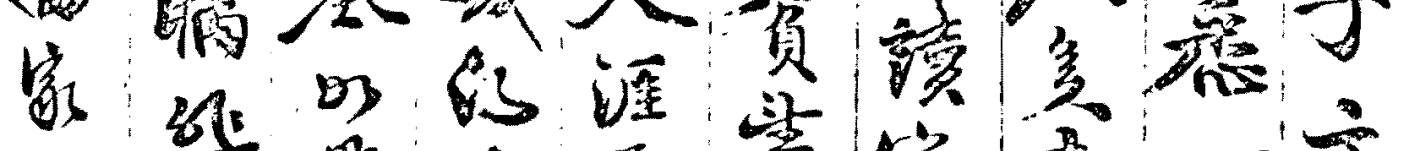

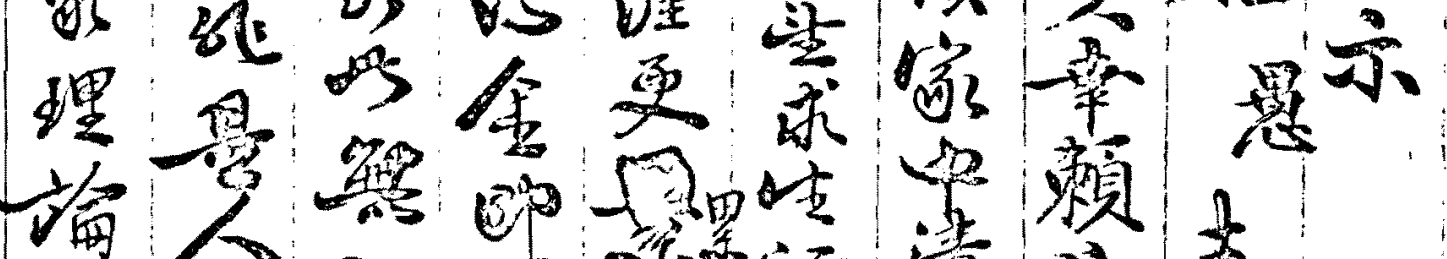

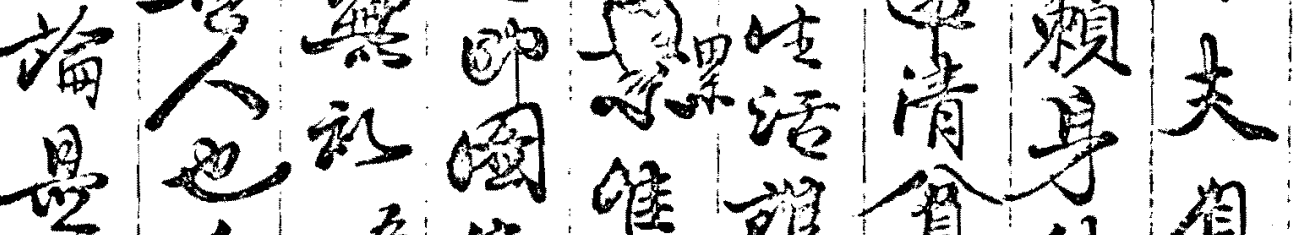

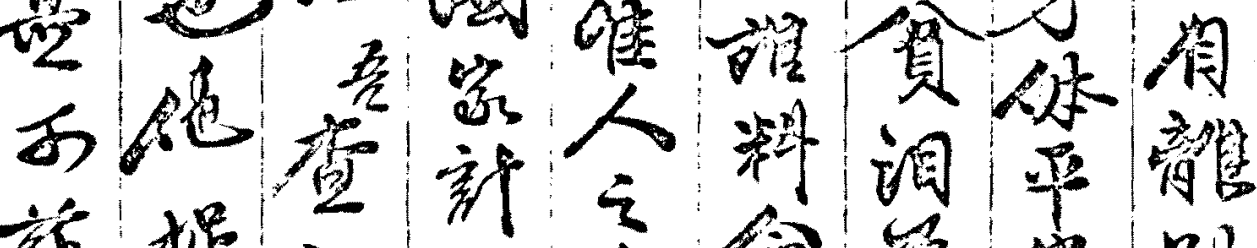

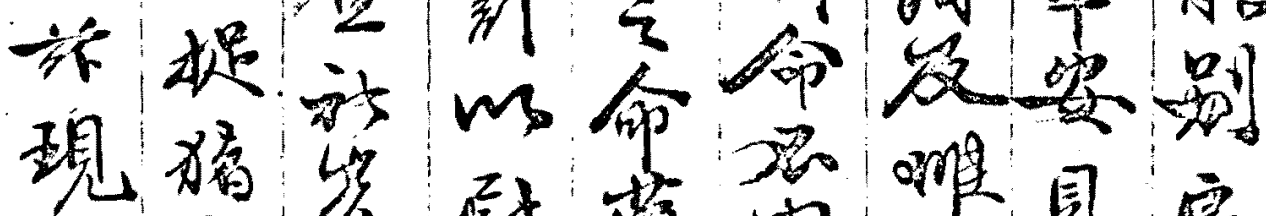

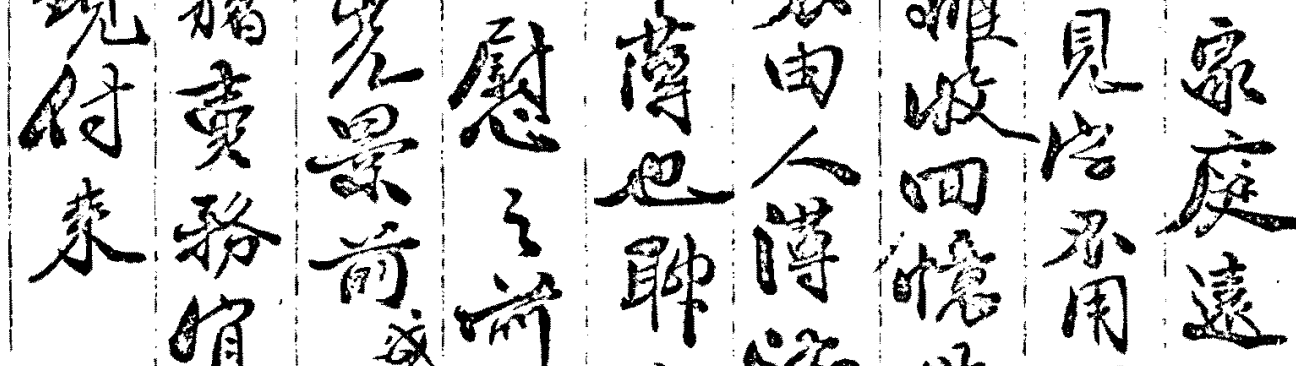

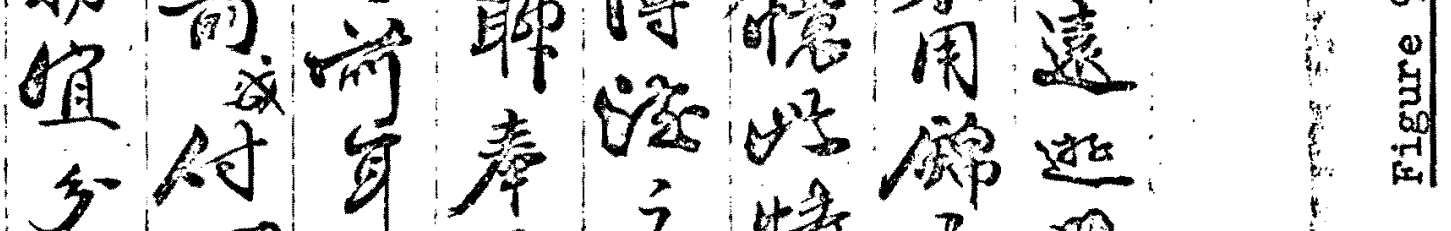

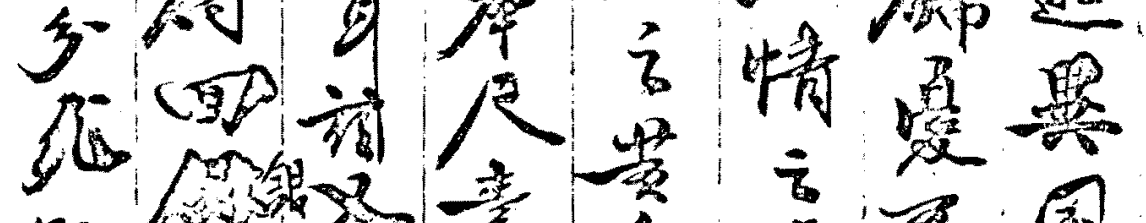

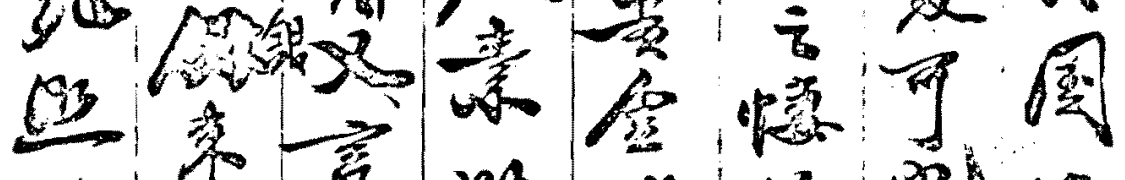

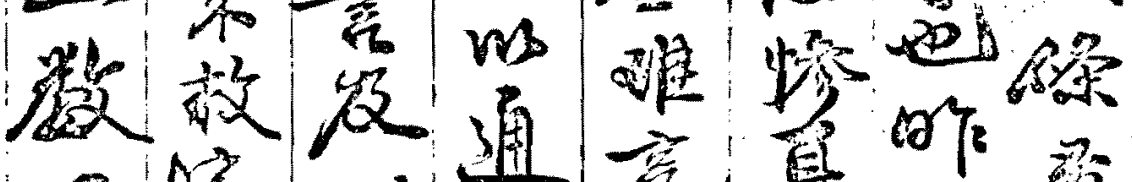

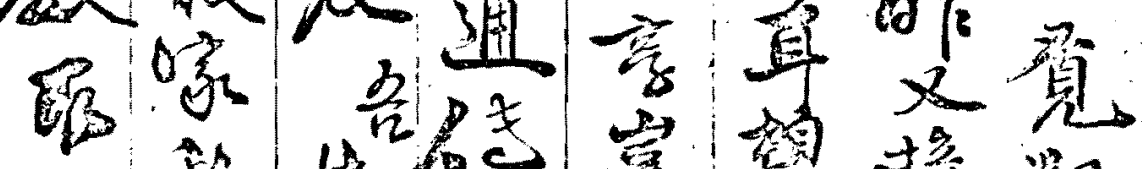

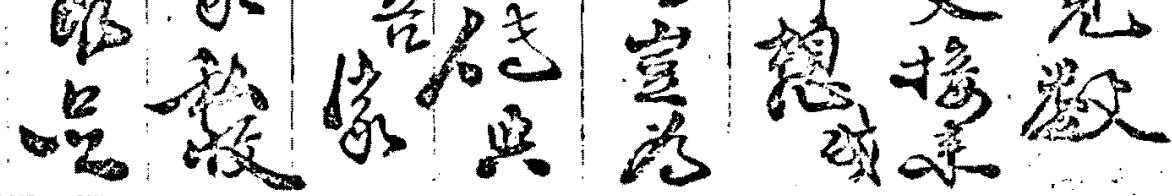




\section{BANK OF CANTON}

COMMERCIAL - SAVINGS

SAN, FRANCISCO, CALIFORNIA

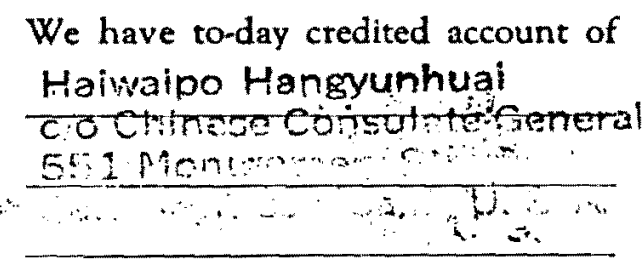

Received from

$\operatorname{ram}$ Wha chine Co.

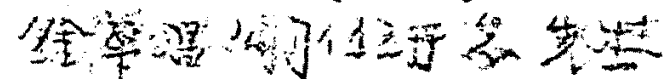

F.C. 30,5 , John Dey, Oregon
$\mathrm{Na} I-510$

June 16,1947
$\mathbf{N} \$$

(a)_U. S. $\$ 50.00$

CHINESE NATIONAL CURRENCY

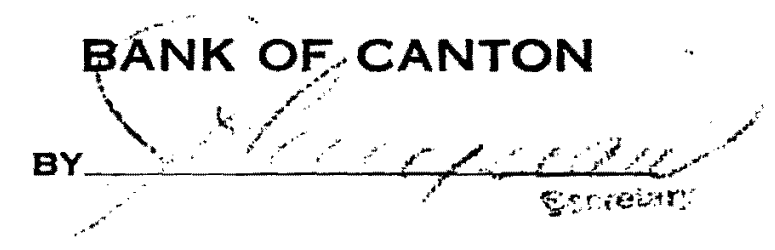

Figure 10. A donation to the Chinese government. 

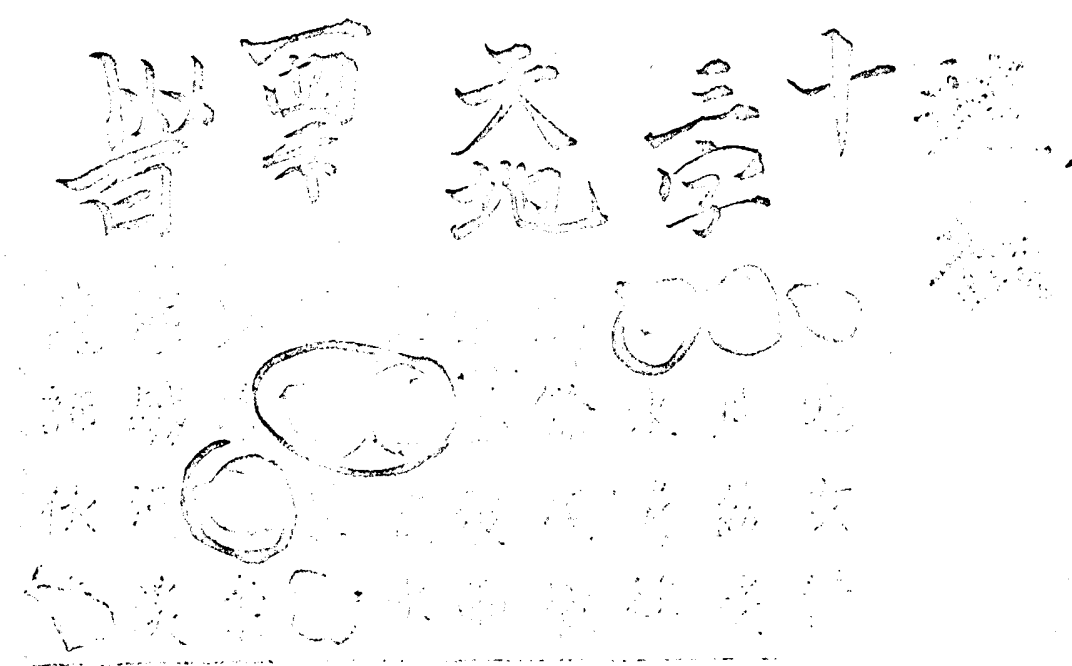

Figure 11. A lottery. 


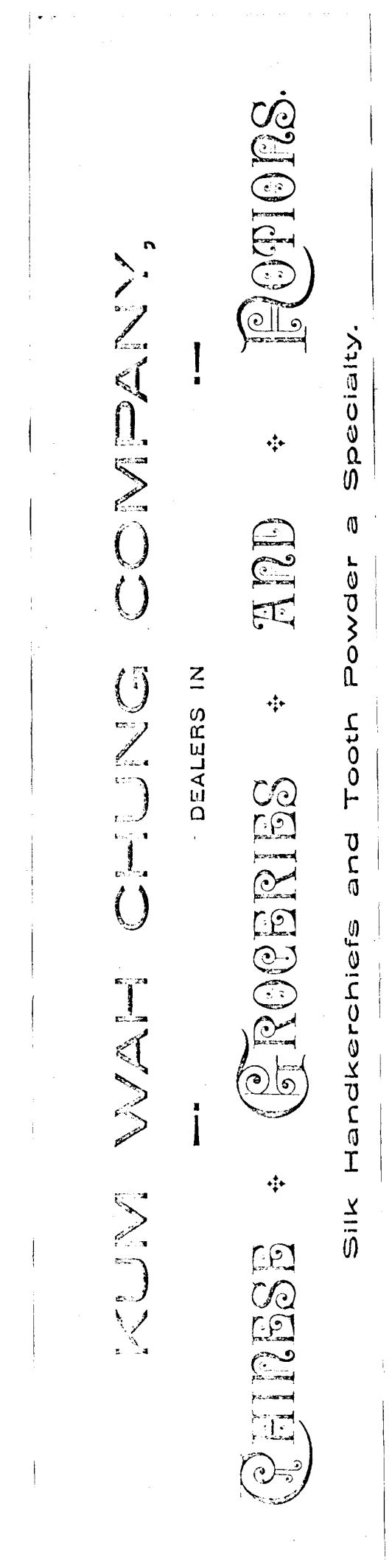

Figure 12. A letter from a cook. 